\author{
UNIVERSIDADE DE SÃO PAULO \\ ESCOLA DE ENGENHARIA DE LORENA
}

ELEASAR SILVA MARINS

O uso de Role-Playing Game (RPG) no ensino de Ciências: uma atividade voluntária e complementar às aulas no Ensino Fundamental II

Lorena - SP

2017 


\section{O uso de Role-Playing Game (RPG) no ensino de Ciências: uma atividade voluntária e complementar às aulas no Ensino Fundamental II}

Dissertação apresentada à Escola de Engenharia de Lorena da Universidade de São Paulo para obtenção do título de Mestre em Ciências do Programa de Mestrado Profissional em Projetos Educacionais de Ciências.

Orientador: Prof. Dr. Paulo Atsushi Suzuki

Edição reimpressa e corrigida

Lorena - SP

Maio, 2017 
AUTORIZO A REPRODUÇÃO E DIVULGAÇÃO TOTAL OU PARCIAL DESTE TRABALHO, POR QUALQUER MEIO CONVENCIONAL OU ELETRÔNICO, PARA FINS DE ESTUDO E PESQUISA, DESDE QUE CITADA A FONTE

Ficha catalográfica elaborada pelo Sistema Automatizado da Escola de Engenharia de Lorena, com os dados fornecidos pelo(a) autor(a)

Marins, Eleasar Silva

O uso de role-playing game (RPG) no ensino de ciências: uma atividade voluntária e complementar às aulas no ensino fundamental II / Eleasar Silva

Marins; orientador Paulo Atsushi Suzuki - ed. reimp., corr. - Lorena, 2017.

$109 \mathrm{p}$.

Dissertação (Mestrado em Ciências - Programa de Mestrado Profissional em Projetos Educacionais de Ciências) - Escola de Engenharia de Lorena da Universidade de São Paulo. 2017

Orientador: Paulo Atsushi Suzuki

1. Jogos e educação. 2. Rpg. 3. Role-playing game. 4. Ensino de ciências. I. Título. II. Suzuki, Paulo Atsushi, orient. 


\section{Em memória de meus amados avós}

Vô Chico e Vó Carminha

Vô Marins e Vó Toninha

Serei sempre grato por tudo que aprendi com vocês. 


\section{AGRADECIMENTOS}

Primeiramente agradeço a Deus pelo dom da vida, pela saúde e por tudo.

Aos meus pais Eleasar e Eneida, pelo apoio sempre presente, pela educação, por me apoiarem na busca pelos meus sonhos e por serem as pessoas maravilhosas que são. Por todos os conselhos e amparos. Por sempre estarem ao meu lado, nos momentos mais difíceis e também nas maiores alegrias. Sem vocês a conclusão deste trabalho não seria possível. É uma honra e uma felicidade enorme compartilhar esse mundo e esta época com vocês. Aprendi e aprendo muito com vocês.

À minha namorada Juliana, pelo apoio, paciência e compreensão nesses três anos de mestrado, por todos os momentos em que esteve presente, nas tempestades e nas calmarias, por ser a pessoa maravilhosa que é e pela motivação para a conclusão deste trabalho. Por todas as coisas que me ensinou. Sou eternamente grato por compartilhar essa época e esse mundo com você.

Ao meu orientador Prof. Dr. Paulo Suzuki, pela orientação e pela confiança, mesmo nos momentos difíceis. Por ter acreditado em mim.

A todos os funcionários e professores do PPGPE e demais servidores da EEL/USP que sempre me atenderam com atenção e carinho.

Ao amigo Luís Fernando, o melhor mestre de RPG que já conheci, que me ensinou a jogar RPG, e a mestrar, criando histórias, mundos e personagens, desde os meus 12 anos. Amigo que sempre esteve presente, com quem aprendi e aprendo muito.

Ao amigo Luis Antonio, por toda a motivação, apoio e conselhos, por estar sempre presente e ter me motivado a seguir em frente nos momentos de tempestade e concluir este trabalho. Aprendo muito com você.

Ao amigo Eduardo que em um momento crucial, me emprestou o livro RPG \& Educação: Pensamentos soltos o qual foi muito importante para toda a concepção desta pesquisa.

À amiga Marina e ao amigo Raphael, pelos conselhos, atenção e carinho sempre presentes.

A todos os amigos e amigas que me motivaram e me aconselharam nesta realização.

Aos alunos que participaram desta pesquisa, foi uma honra e uma felicidade enorme jogar RPG com vocês.

À direção e coordenação do colégio ACADI Monteiro Lobato, bem como a toda equipe do colégio e colegas professores, que apoiaram a realização deste trabalho.

Ao senhor Marcelo Cardoso, terapeuta, mentor, conselheiro e amigo, que muito contribuiu para a realização deste trabalho, sua ajuda foi vital para a conclusão deste mestrado.

À amiga Jacqueline pela contribuição encontrando alguns artigos que foram muito importantes nesta pesquisa.

À minha prima Alessandra pela contribuição com a construção das fases iniciais de um projeto que levou a esta pesquisa.

Aos amigos e colegas de mestrado Gerson e Marcos pelas conversas, motivação e cooperação ao longo do curso.

A todos os meus alunos, alunas, ex-alunos e ex-alunas, pela motivação, pelo respeito e carinho e por cooperarem em aprendermos juntos. 
"A imaginação é mais importante que o conhecimento." Albert Einstein 
MARINS, E. S. O uso de Role-Playing Game (RPG) no ensino de Ciências: uma atividade voluntária e complementar às aulas no Ensino Fundamental II. 2017. 109p. Dissertação (Mestrado em Ciências). - Escola de Engenharia de Lorena, Universidade de São Paulo, Lorena, 2017.

\section{RESUMO}

Nesta pesquisa é proposto o uso Role-Playing Game, mais conhecido como RPG, como uma estratégia no processo de ensino e aprendizagem no ambiente escolar. Os estudos com RPG e educação demonstram grande potencial como tecnologia educacional, proporcionando aprendizagem ativa e significativa modificando a forma como se ensina. Este trabalho teve como objetivos: investigar sobre as possibilidades educacionais da implementação do roleplaying game (RPG) no ambiente escolar como uma atividade pedagógica complementar e voluntária no ensino de ciências, verificar a aprendizagem de conceitos fundamentais de ciências que foram expostos aos alunos através do RPG, bem como analisar as impressões dos alunos quanto ao contato desses conteúdos de ciências por meio do RPG e também quanto à experiência de jogar RPG no ambiente escolar com o professor. Para tanto procurou-se inicialmente, um levantamento bibliográfico de algumas obras que discutem os problemas educacionais brasileiros e expõem estratégias para solucioná-los, dentre essas, destacou-se as que verificam a viabilidade da utilização de jogos didáticos. Em seguida, essa pesquisa sintetiza as publicações referentes ao uso de jogos de RPG, na educação em diversos níveis e faixas etárias. Em seguida, faz-se uma breve descrição do que é RPG, e da metodologia usada nesse trabalho, no qual foi realizado um experimento com alunos do oitavo ano do ensino fundamental que jogaram RPG no ambiente escolar, de maneira voluntária e fora do horário de aula, juntamente com o professor, que abordou por meio do jogo, conceitos de ciências, como: ácido, base, escala de pH, densidade, as três Leis de Newton e também morfologia de artrópodes - insetos. Para o levantamento dos dados foi utilizado uma pesquisa qualitativa exploratória por meio da observação, questionários e um teste para avaliar o aprendizado de ciências, principalmente dos conceitos de ácido, base e escala de $\mathrm{pH}$. Os resultados apontam elevado potencial do uso do role-playing game na escola como uma atividade voluntária e complementar ao ensino de ciências, bem como a formação do aluno em geral, pois além da eficiência do uso pedagógico deste jogo para o ensino de ciências, observou-se que o RPG além de motivar os alunos, proporcionou um ambiente de cooperação, interação, construção conjunta do conhecimento e criatividade.

Palavras chave: Jogos e educação. RPG. Role-playing game. Ensino de ciências 
MARINS, E. S. The use of Role-Playing Game (RPG) in science teaching: a voluntary activity and complementary to classes in Elementary School II. 2017. 109p. Dissertation (Master of Science). - Escola de Engenharia de Lorena, Universidade de São Paulo, Lorena, 2017.

\begin{abstract}
In this research it is proposed to use Role-Playing Game, better known as RPG, as a strategy in the process of teaching and learning in the school environment. Studies in RPG and education demonstrate great potential as an educational technology, providing active and meaningful learning by modifying the way it is taught. The objective of this study was to investigate about the educational possibilities of the role-playing game (RPG) in the school environment as a complementary and voluntary pedagogical activity in science teaching, to verify the learning of fundamental science concepts that were exposed to the students through RPG, as well as analyzing students' impressions regarding the contact of these science content through the RPG and also the experience of playing RPG in the school environment with the teacher. In order to do so, a bibliographical survey of some works that discuss Brazilian educational problems and strategies for solving them was presented, among them, those that verify the viability of the use of didactic games. Next, this research synthesizes publications regarding the use of RPG games in education at various levels and age groups. Next, a brief description of RPG is given, and the methodology used in this work, in which an experiment was carried out with eighth grade elementary students who played RPGs in the school environment, voluntarily and outside of school classroom hours, along with the teacher, who approached through the game, science concepts such as: acid, base, $\mathrm{pH}$ scale, density, the three Laws of Newton and also arthropods morphology - insects. For the data collection a qualitative exploratory research was used through observation, questionnaires and a test to evaluate the learning of sciences, aim at the learning of acid, base and $\mathrm{pH}$ scale concepts. The results point out a high potential of the use of role-playing game in school as a voluntary activity and complementary to the teaching of sciences, as well as the formation of the student in general, because besides the efficiency of the pedagogical use of this game for the science teaching, observed That the RPG besides motivating the students, provided an environment of cooperation, interaction, joint construction of knowledge and creativity.
\end{abstract}

Keywords: Games and education. RPG. Role-playing game, Science teaching 


\section{LISTA DE ILUSTRAÇÕES}

Figura 1 Dados de RPG utilizados: da esquerda para a direita apresenta-se respectivamente o dado de 20 faces, o de 12 faces, o de 10 faces, o de 8 faces, o de 6 faces e o de 4 faces.

Figura 2 Alunos em uma das sessões de RPG ocorridas durante a pesquisa. 


\section{LISTA DE TABELAS}

Tabela 1 - Como o jogo influenciou o seu relacionamento com seus colegas de equipe?

Tabela 2 - Por que você acha que o RPG deve ser uma atividade utilizada nas aulas, seja ela qual for?

Tabela 3 - Como você acha que o RPG pode facilitar o processo de aprendizagem?

Tabela 4 - Quais valores e habilidades você acha que o RPG pode ajudar a desenvolver?

Tabela 5 - Respostas referente à pergunta dissertativa: "Escreva um texto, de no mínimo 10 linhas e no máximo 30 linhas, descrevendo como foi para você vivenciar essa experiência de jogar RPG na escola."

Tabela 6 - Respostas referentes à pergunta dissertativa: "Você recomendaria o uso do RPG na escola? Ou você não recomendaria o uso do RPG na escola? Argumente sua opinião."

Tabela $7 \quad-$. Respostas referentes às perguntas dissertativas: "Você aprendeu algum conceito novo de ciências jogando o RPG? Se sim quais foram estes conteúdos? E houve algum momento da história do RPG em que você e sua equipe tiveram de usar esse conhecimento em ciências? Se sim, descreva como foi esse momento." E também: "Escreva um texto, de no mínimo 10 linhas e no máximo 30 linhas, descrevendo como foi para você vivenciar essa experiência de jogar RPG na escola." 


\section{LISTA DE ABREVIATURA E SIGLAS}

RPG - Role -Playing Game

$\mathrm{pH}$ - Potencial hidrogênico

ZDP - Zonas de Desenvolvimento Proximal

NPC - Non-Player Character

D\&D - Dangeons and Dragons 


\section{SUMÁRIO}

2 OBJETIVOS 23

2.1 OBJETIVO GERAL 23

2.2 OBJETIVOS ESPECÍFICOS 23

3 REVISÃO DA LITERATURA 24

3.1 A NECESSIDADE DE NOVAS METODOLOGIAS DE ENSINO 24

3.2 CAMINHOS PARA A NOVA EDUCAÇÃO 32

3.3 O USO DOS JOGOS NA EDUCAÇÃO 42

3.4 UMA BREVE EXPLICAÇÃO SOBRE ROLE-PLAYING GAME 47

3.5 O USO DO ROLE-PLAYING GAME NA EDUCAÇÃO 53

4 METODOLOGIA 62

4.1 PROCEDIMENTOS PRELIMINARES À PESQUISA 62

4.2 A PESQUISA 63

4.2.1 Os sujeitos da pesquisa $\quad 63$

4.2.2 Os temas de ciências abordados durante as partidas $\quad 65$

4.2.3 As regras do RPG jogado durante a pesquisa $\quad 66$

4.2.4 Instrumentos de coleta de dados 68

5 RESULTADOS E DISCUSSÕES

5.1 APRENDIZAGEM DOS CONCEITOS FUNDAMENTAIS DE ÁCIDO,

BASE E ESCALA DE POTENCIAL HIDROGÊNICO, POR MEIO DO USO DO RPG COMO ESTRATÉGIA EDUCACIONAL 71

5.2 AS IMPRESSÕES DOS ALUNOS QUANTO A EXPERIÊNCIA DE JOGAR ROLE-PLAYING GAME NO AMBIENTE ESCOLAR COM O PROFESSOR 74

5.2.1 O cenário e a história da campanha jogada: as principais observações relacionadas ao comportamento e ações dos alunos durante estes momentos de imaginação e ludicidade 75

5.2.2 Interpretação das respostas dos alunos ao questionário múltipla escolha $\quad 84$

5.2.3 Interpretação das respostas dos alunos às perguntas dissertativas $\quad 87$

5.3 AS IMPRESSÕES DOS ALUNOS QUANTO AO CONTATO COM CONTEÚDOS DA DISCIPLINA DE CIÊNCIA POR MEIO DO ROLEPLAYING GAME

6 CONCLUSÕES

REFERÊNCIAS 101

ANEXO A: teste ácido, base e escala de $\mathrm{pH} \quad 108$ 


\section{INTRODUÇÃO}

No processo de ensino e aprendizagem é de grande importância a constante busca por formas de ensino que favoreçam o envolvimento ativo do aluno na aprendizagem (MARIN et al., 2010). É necessário que o papel de protagonista do processo de aprendizagem seja assumido pelos estudantes, possibilitando que o aluno seja o construtor de seu próprio conhecimento, incentivando e proporcionando de maneira motivadora uma aprendizagem por meio da solução de situações problemas, permitindo aprender de maneira significativa (DOWBOR, 2001; SILVA, 2009; MORAES, 2016).

Tal maneira de ensino e aprendizagem ativa pode formar pessoas capazes de articular e utilizar os conhecimentos e habilidades adquiridos, conectar diferentes habilidades e inteligências, trabalhar de maneira cooperativa, raciocinar de modo multidisciplinar, avaliar, pesquisar, ser capaz de inovar, agir com autonomia, pensar com criatividade, refletir e questionar. Esta formação deve ser o objetivo da educação no cenário mundial atual, formando pessoas com tais habilidades e com consciência global, sustentável e ética. A humanidade precisa de pessoas com essa formação, que sejam motivadas e capazes de transformar panoramas e encontrar soluções (DOWBOR, 2001; LIMA, 2015; MORAES, 2016; REEVE, 2009).

No entanto, o quão motivadora e transformadora é hoje a escola para os seus alunos? O atual sistema educacional brasileiro está cumprindo o seu objetivo de proporcionar esta formação?

De acordo com a autora Moraes (2016) o atual sistema educacional não leva o aluno a aprender a pensar para solucionar problemas, a fazer questionamentos para compreender melhor. A autora afirma que a educação enfrenta a realidade com ferramentas intelectuais de tempos passados, de outras épocas, inadequadas ao cenário atual. É de grande importância o estudo de novas estratégias, métodos e tecnologias de ensino (DOWBOR, 2001; MORAES, 2016; SILVA, 2009).

Segundo Dowbor (2001) o mundo de hoje constitui ao mesmo tempo um desafio e uma oportunidade no universo da educação. É um desafio devido a velocidade e a profundidade com a qual o universo do conhecimento está sendo transformado, e uma oportunidade pois o conhecimento, que é a matéria-prima da educação, está se tornando o recurso estratégico do desenvolvimento moderno. 
Dowbor (2001) afirma em sua obra que a educação, e os sistemas de gestão do conhecimento que se desenvolvem em torno dela, têm de aprender a utilizar as novas tecnologias para transformar a educação, na mesma proporção que estas tecnologias estão transformando o mundo, e que a transformação é de forma e conteúdo.

Dentre as novas metodologias de ensino, muitas pesquisas demonstram o potencial dos jogos no processo de ensino e aprendizagem, indicando diversos fatores positivos do uso dos jogos na transformação da educação (BROUGÈRE, 2002; FERREIRA et al., 2007; JULIANI; PAINI, 2008; RAMOS, 2015).

Nesta proposta do uso do jogo na educação, a presente pesquisa tem o seu foco no uso do Role-Playing Game, mais conhecido como RPG, como uma estratégia no processo de ensino e aprendizagem no ambiente escolar.

O RPG tem sido objeto de estudo de muitas pesquisas no cenário educacional. Os estudos com RPG e educação demonstram grande potencial desta modalidade de jogo como tecnologia educacional, proporcionando aprendizagem ativa e significativa, mudando paradigmas no cenário da educação, modificando a forma como se ensina e o conteúdo, auxiliando na construção de uma escola mais relacionada ao mundo atual (ANDRADE; CARNEIRO, 2007; CAVALCANTI; SOARES, 2009; CHUNG, 2013; FERREIRA et al., 2007; LOPES; KLIMICK; CASANOVA, 2003; OLIVEIRA; PIERSON; ZUIN, 2009; RODRIGUES, 2004; SILVA, 2009).

Motivada pelas qualidades do RPG como tecnologia educacional demonstradas na literatura, e pela grande necessidade de novos métodos de ensino que transformem o sistema educacional, esta pesquisa buscou analisar o uso do Role-Playing Game no ensino de Ciências.

Neste estudo o RPG foi aplicado como uma atividade voluntária e complementar às aulas estabelecidas no cronograma escolar, aplicado fora do período das aulas, com alunos do oitavo ano do Ensino Fundamental, visando aproveitar o caráter lúdico do RPG, juntamente com todas as características de valor educacional que este jogo por si só apresenta, somado à conteúdos da disciplina de ciências. Buscando ao invés de abrir espaço na aula para o jogo, abrir espaço no jogo para a aula. Uma aula ativa proporcionando a aprendizagem por meio da solução de problemas, mesclando as fronteiras entre jogo e aula e, propondo uma prática que pode se tornar uma nova atividade presente no ambiente escolar. 


\section{OBJETIVOS}

\subsection{OBJETIVO GERAL}

Este trabalho teve como objetivo avaliar a eficiência do Role-Playing Game como estratégia educacional para melhorar o ensino de Ciências.

\subsection{OBJETIVOS ESPECÍFICOS}

- Investigar sobre as possibilidades educacionais da implementação do roleplaying game no ambiente escolar como uma atividade pedagógica complementar e voluntária.

- Verificar a aprendizagem dos conceitos fundamentais de ácido, base e escala de $\mathrm{pH}$, conteúdo da disciplina de ciências o qual foi escolhido nesta pesquisa para ser ensinado por meio do role-playing game.

- Verificar as impressões dos alunos quanto ao contato com conteúdos da disciplina de ciência por meio do role-playing game.

- Verificar as impressões dos alunos quanto a experiência de jogar roleplaying game no ambiente escolar com o professor. 


\section{REVISÃO DA LITERATURA}

Neste capítulo é apresentado um referencial na literatura sobre as necessidades de novas metodologias de ensino e sobre a nova visão de educação. Serão abordadas teorias de aprendizagem que fundamentam o uso de jogos, especialmente o uso de role-playing game (RPG), no processo de ensino e aprendizagem, bem como bases na literatura para a proposta de aprendizagem por meio do RPG. Será exposta também uma breve explicação sobre o que é role-playing game, e como esse jogo funciona.

\subsection{A NECESSIDADE DE NOVAS METODOLOGIAS DE ENSINO}

$\mathrm{O}$ modelo de ensino tradicional ainda continua presente e dominante nos dias atuais. A autora Moraes (2016) descreve como o atual sistema educacional permanece buscando solucionar desafios da sociedade nos dias de hoje com ferramentas intelectuais de épocas passadas, ineficientes para o cenário atual.

O sistema educacional, embora tenha se modificado, não apresenta mudanças significativas na prática de suas metodologias, e mesmo hoje no século XXI ainda se agarra a uma metodologia de séculos passados, como descreve o autor Silva quando afirma que:

O modelo de ensino tradicional continua o mesmo em escolas do Ensino Médio, apesar das transformações pelas quais a sociedade passa e das novas exigências pessoas e profissionais. A sociedade mudou, as pessoas mudaram, os valores mudaram, podemos dizer que a visão de educação mudou, o contexto sócio-histórico é outro, mas pouco foi alterado na prática, inclusive na educação pública brasileira. (SILVA, 2009, p. 59).

Sobre o cenário atual da educação a autora Moraes afirma que:

A realidade educacional, como hoje se apresenta, não deixa de ser um grande desafio para a maioria dos professores acostumada a trabalhar 
com certezas e verdades, com causalidade linear, previsibilidade e estabilidade. Para qualquer ser humano, é difícil compreender o caos, a ordem fazendo parte da desordem, a incerteza e o indeterminismo inseridos na dinâmica da vida $\mathrm{e}$, hoje, tão presentes na realidade construída e nas relações que acontecem nos ambientes educacionais. $\mathrm{Na}$ verdade, enfrentamos tempos incertos e fluidos com ferramentas intelectuais de outras épocas, de outros tempos, observando a realidade como se fosse estável, homogênea e pré determinada. (MORAES, 2016, p. 1).

Segundo Moraes $^{1}$ (1997 apud SILVA, 2009) a maioria das escolas despendem mais energia com rotinas administrativas do que com a aprendizagem dos alunos. As escolas tendem a dar mais atenção para as questões burocráticas, como por exemplo, histórico escolar, avaliações documentadas, relatórios de classe entre outros, do que com a aprendizagem dos alunos em si. A aprendizagem do discente acaba não sendo o foco central da escola, e é observado um despreparo na maioria das escolas para melhorar o processo de ensino e aprendizagem.

A autora afirma que como consequências, as escolas de maneira geral não cumprem o seu objetivo. O sistema educacional está dissociado do mundo e da vida atual, gerando insatisfações de pais e alunos. Os professores, em sua maioria, encontram-se desmotivados, o que pode ser por diversas razões, seja devido aos baixos salários, seja pela falta de incentivo do governo, ou pela falta de condições didático-pedagógicas e de infraestrutura, ou até mesmo pela acomodação do próprio professor que não busca alternativas. A falta de uma política de valorização do docente tornou o magistério uma área muito pouco prestigiada e de baixa atratividade no mercado de trabalho. A desvalorização do professor faz com que a maioria dos professores não se motive pela sua profissão, consequentemente não apresentando um bom desempenho em seu trabalho.

Uma mudança é necessária nos métodos de ensino, pois o ensino tradicional, baseado em memorização dos conteúdos, é ineficiente no desenvolvimento de capacidades para a reflexão e construção de conhecimentos (LIMA, 2015). Pode-se concordar com Moraes que:

\footnotetext{
${ }^{1}$ MORAES, M. C. O paradigma educacional emergente. Campinas: Papirus, 1997.240 p
} 
$\mathrm{Na}$ verdade, muitos professores ainda continuam condicionados pelo pensamento linear e determinista, vendo o erro como expressão de ignorância e incompetência, o conhecimento cada vez mais dividido, fragmentado e o aluno como um "banco de dados" a ser abarrotado de informações inúteis. Predomina um modelo de escola que continua oferecendo espaços quadriculados e testes de múltipla-escolha em vez de desenvolver processos criativos, interativos, construtivos e colaborativos de produção do conhecimento. É um modelo de ensino que exige memorização, repetição e cópia, que enfatiza conteúdos, resultados e produtos, esquecendo a riqueza, a beleza dos processos e a importância do diálogo interdisciplinar e transdisciplinar (MORAES, 2016, p. 2).

Este modelo de ensino ocasiona a desmotivação e o desinteresse dos alunos "A falta de interesse e desmotivação dos estudantes têm se mostrado um fator problemático para os professores que atuam em escolas de Ensino Básico” (LIMA, 2015, p. 10). Novas metodologias de ensino são essenciais para a sociedade e são uma emergência, pois como afirma a autora Moraes:

Analisando a realidade de alguns países, percebe-se facilmente a existência de duas realidades superpostas e de naturezas opostas. Uma constituída pela expansão vertiginosa e acentuada das tecnologias digitais presentes nos mais diferentes âmbitos e uma outra constituída pela expansão acelerada da pobreza, da fome, da miséria e de outros tipos de violência e de exclusão social que vêm afetando a vida de todo cidadão/ã. É uma problemática complexa de natureza transnacional, transdisciplinar e transcendental e que, por sua vez, requer soluções compatíveis com a sua natureza complexa. Esta problemática também nos sugere que nem sempre o crescimento econômico e tecnológico é o motor necessário e suficiente para o desenvolvimento moral, psíquico e emocional da sociedade (MORAES, 2016, p. 2).

Como afirma o autor Dowbor “A educação já não pode funcionar sem se articular com dinâmicas mais amplas que extrapolam a sala de aula" (DOWBOR, 2001, p. 1). O autor afirma que estamos avançando rapidamente para uma sociedade do conhecimento e que problemática da educação se tornou central para todos nós, para que possa ocorrer o 
desenvolvimento econômico e social. A importância de uma nova educação, eficiente para a sociedade atual, fica clara na afirmação:

As tecnologias em si não são ruins. Fazer mais coisas com menos esforço é positivo. Mas as tecnologias sem a educação, conhecimentos e sabedoria que permitam organizar o seu real aproveitamento, levam-nos apenas a fazer mais rápido e em maior escala os mesmos erros. Achávamos que o essencial para desenvolver o país seria criar fábricas e bancos. Hoje constatamos que sem os conhecimentos e a organização social correspondente, construímos uma modernidade com pés de barro, um luxo de fachada que já não engana mais ninguém. (DOWBOR, 2001, p. 1).

A sociedade atual enfrenta uma crise ampla em complexa em diversos campos. São crises de natureza ecológica, energética, econômica, existencial e educacional. Também ocorre uma crise nos fundamentos do conhecimento, uma crise de natureza epistemológica e filosófica, que ocorre a partir dos avanços da ciência já no inicio do século passado até o presente. Esta crise está relacionada à descoberta da inexistência da certeza absoluta na interpretação da realidade, e leva à crises de natureza antropológica. A amplitude vasta e complexa dessa crise na sociedade, a qual permeia diversos campos, ocasiona múltiplas implicações que estão causando sequelas sociais, culturais, políticas e educacionais. Os impactos de tais sequelas atingem a educação de maneira geral e principalmente a escola, diminuindo cada dia mais a qualidade da educação oferecida, afetando a maneira de se resolver os problemas educacionais (MORAES, 2016).

A necessidade de mudanças nas metodologias de ensino é evidente e necessária para que o ensino escolar acompanhe as mudanças que ocorrem na sociedade atual, chamada de sociedade do conhecimento. Novas metodologias de ensino são, não somente, uma necessidade urgente, como também são possíveis, pois o cenário atual é um momento de oportunidade para tais mudanças na educação (CARVALHO, 2013; BECKER, 2016; DOWBOR, 2001; MORAES, 2016; SILVA, 2009; VOGT, 2010).

Não basta incorporar novas tecnologias na sala de aula, pois na sociedade mudamse as tecnologias, mas também muda o mundo a ser estudado e, portanto é preciso mudar a maneira de ensinar (DOWBOR, 2001). 
Ainda hoje o modelo de ensino tradicional é aplicado nas escolas. Mesmo com a incorporação de novas tecnologias em sala de aula, a maneira de se ensinar permanece a tradicional. A escola continua incentivando, direta ou indiretamente, o individualismo. Pois uma vez que o incentivo é o mesmo, ou seja, a aula e as notas, o estudante que se destaca nas notas ainda é tido como melhor do que os outros. Não se é percebido na prática escolar que a motivação e as capacidades de cada aluno são diferentes. Na maioria das vezes, o ensino é realizado sem levar em conta que cada aluno traz consigo uma bagagem intelectual própria, uma história de vida, e que o fato de não se destacar nas notas, não é sinônimo de fracasso. Na prática as inteligências múltiplas de cada estudante não são consideradas, todos são tratados com a mesma metodologia, são todos expostos a uma mesma maneira de se ensinar (DOWBOR, 2001; MORAES, 2016; SILVA, 2009).

Hargreaves (2003) afirma que ao invés de fomentar a criatividade e engenhosidade, cada vez mais sistemas educacionais se tornaram obcecados por impor e controlar, em detalhes, a uniformidade curricular. No lugar de investir em ambiciosas missões de compaixão e comunidade, as escolas e os professores têm sido espremidas em uma visão limitada de testes, notas, formulários, metas de realizações, geralmente vinculadas à quantidade de conteúdos, e tabelas de classificação. Muitas escolas estão ficando presas, empacadas, em regulamentos e padronização sem alma, não valorizando a linguagem emocional dentro do aprendizado. E não investem em cultivar uma identidade cosmopolita e as emoções básicas da simpatia, afeto e solidariedade.

A maneira de se ensinar no atual sistema educacional, pouco mudou em mais de um século. Um contraste em relação ao mundo em volta da escola o qual muito mudou nos últimos cem anos. Ter computadores, internet, projetores, lousas digitais dentro da sala de aula, não é sinônimo de uma nova metodologia de ensino (DOWBOR, 2001; MARIN et al., 2010; MORAES, 2016; SILVA, 2009). Pode-se concordar com a afirmação da autora Moraes:

[...] a educação continua ainda gerando padrões de comportamentos tendo como referência um sistema educacional que não leva o indivíduo a aprender a pensar para solucionar problemas, a questionar para compreender melhor, preferindo aceitar passivamente a autoridade e a ter "plena certeza" das coisas. É um enorme desafio quando observamos, com tristeza, as escolas "protegidas" por grades, os laboratórios de informática trancados, as crianças entrincheiradas nos espaços reduzidos 
de suas carteiras escolares, imobilizadas em seus movimentos, silenciadas em suas falas, impedidas de pensar e de expressar suas emoções e sentimentos. $\mathrm{Na}$ realidade, em muitas escolas, alunos encontram-se impossibilitados de expressar o que pensam, presos à uma mente técnica e à um coração vazio e sem esperança, impedidos de alçar novos vôos e conquistar novos espaços.(MORAES, 2016, p. 1-2).

A presença de recursos digitais em sala de aula não necessariamente transforma as metodologias tradicionais de ensino. Devido à falta da prática de uma didática que saiba utilizar todas as possibilidades destes recursos, para inovar o processo de ensino e aprendizagem, prevalecendo o modelo de ensino tradicional, apenas mudando a mídia pela qual ele é aplicado. Como afirma os autores Monteiro M., Germano e Monteiro I.:

[...] apesar do grande desenvolvimento de softwares voltados para a educação e do crescimento do número de escolas que dispõem de tais recursos, muitos professores não sabem como utilizá-los em sala de aula. Esse desconhecimento se estabelece tanto em relação ao funcionamento de tais equipamentos como na maneira didático-pedagógica de desenvolver e dirigir atividades de ensino. Por isso, na maioria das vezes, muitas iniciativas não conseguem ultrapassar os procedimentos tradicionais de transmissão de informação: constituindo-se em simples transferência de páginas dos livros didáticos para a tela do computador (MONTEIRO, M.; GERMANO; MONTEIRO, I., 2008, p. 1).

Até mesmo no Ensino Superior a influência do método tradicional de ensino ainda é fortemente presente, o que leva a formação profissional desarticulada do contexto social e político (MARIN et al., 2010).

Os conceitos tradicionais escolares resistem em compartilhar espaço com o novo (MORAES $^{2}, 2004$ apud SILVA, 2009). Segundo Cortelazzo (2000), juntamente com a resistência do tradicional em relação ao novo, existe a predominância do ensino baseado na linguagem verbal escrita, a autora afirma que as escolas permanecem impermeáveis às

\footnotetext{
${ }^{2}$ MORAES, M. C. O pensamento eco-sistêmico:educação, aprendizagem e cidadania no século XXI. Petrópolis: Vozes, 2004
} 
mudanças que afetam a sociedade e que as novas gerações frequentam uma escola semelhante a de gerações de outras épocas:

Muitas escolas permanecem como que impermeáveis às mudanças que afetam tanto a sociedade estruturalmente quanto as atividades de produção e de trabalho. As novas gerações frequentam uma escola semelhante aquela que nossos avós frequentaram [...] (CORTELAZZO, 2000, p. 1-2).

Quanto ao contraste das metodologias de ensino aplicadas dentro da escola, com relação ao mundo que a rodeia nos dias de hoje, o autor Silva afirma:

É de se entender o porquê de pais, alunos e professores estarem insatisfeitos com a escola. O trabalho educacional é anacrônico. Dentro das salas de aula, o conhecimento é separado e rígido e ao sair de lá, vemos que o conhecimento é dinâmico e interligado (SILVA, 2009, p. $60)$.

A sociedade atual é chamada de sociedade da informação/conhecimento, a qual é caracterizada pela enorme variedade de meios de comunicação, de tecnologias e informação, em um mundo globalizado (COUTINHO; LISBÔA, 2011; CRUZ, 2008; HARGREAVES, 2003). A escola não é mais a primeira, e algumas vezes nem mesmo a principal, fonte de conhecimento para os alunos em muitos domínios na sociedade da informação. Porém nem toda informação que alcança até os alunos se transforma realmente em conhecimento (POZO; CRESPO, 2009).

Nos dias de hoje todas as pessoas, na maioria, adquirem um grande número de informações diariamente, devido às características da sociedade da informação, chegando inclusive, a produzir uma saturação informativa. Os estudantes muitas vezes nem precisam procurar pela informação, ela própria é que chega até eles, na maioria das vezes em formatos mais rápidos e encantadores do os apresentados pela escola. No entanto, a simples aquisição de informações não constitui um saber, se não for seguida da compreensão dos seus significados e contextos. A necessidade de saber processar a informação é de grande importância, pois para transforma-la em conhecimento, é necessária a capacidade reflexiva e crítica do indivíduo perante o conteúdo que a 
informação traz. Sem a capacidade da pessoa de analisar, refletir, compreender e saber utilizar o conteúdo adequadamente, a informação se torna inútil para o crescimento intelectual do sujeito. A capacidade reflexiva do aluno é de extrema importância, uma vez que é ela que torna o estudante hábil para interpretar, ponderar, comparar e associar as informações (CRUZ, 2008; LIMA, 2015; MORAES, 2016; POZO; CRESPO, 2009).

Quanto ao ensino de ciências Pozo e Crespo (2009) enfatizam o contraste entre o quanto a sociedade mudou, desde a constituição das instituições escolares, no século XIX, até os dias atuais no século XXI, e o quão pouco o ensino de ciências mudou neste mesmo intervalo de tempo, permanecendo praticamente com o mesmo currículo, o mesmo formato e com as mesmas metodologias do século XIX:

O problema é justamente que o currículo de ciências praticamente não mudou, enquanto a sociedade à qual vai dirigido esse ensino da ciência e as demandas formativas dos alunos mudaram. $\mathrm{O}$ desajuste entre a ciência que é ensinada (em seus formatos, conteúdos, metas, etc.) e os próprios alunos é cada vez maior, refletindo uma autêntica crise na cultura educacional, que requer adotar não apenas novos métodos, mas, sobretudo, novas metas, uma nova cultura educacional que, de forma vaga e imprecisa, podemos vincular ao chamado construtivismo. [...] este enfoque é bastante mais adequado do que os formatos tradicionais para a forma como o conhecimento científico é elaborado na própria evolução das disciplinas, é aprendido do ponto de vista psicológico e é distribuído e divulgado na nova sociedade da informação e do conhecimento, no limiar do século XXI. A nova cultura da aprendizagem que se abre neste horizonte do século XXI é dificilmente compatível com formatos escolares e metas educacionais que praticamente não mudaram desde que as instituições escolares foram constituídas no século XIX. (POZO; CRESPO, 2009, p. 19-20).

Aplicar novas metodologias de ensino que proporcionem uma melhoria do cenário educacional é uma necessidade urgente. Como alerta a autora Moraes:

Se o futuro é produto de uma construção individual e coletiva, certamente o que realizarmos agora, ou deixarmos de realizar, afetará o nosso futuro e o futuro dos nossos filhos e netos. Qualquer omissão, silêncio ou ignorância no momento presente certamente tem o seu preço e este não 
será insignificante. Muito pelo contrário! Daí a importância de estarmos conscientes das demandas e necessidades atuais, conscientes dos nossos atos, das nossas omissões, da nossa covardia, ignorância ou incompetência no trato das questões educacionais. Assim, é importante perguntar:que preço estamos dispostos a pagar? (MORAES, 2016, p.3).

É emergencial uma mudança de paradigmas em relação aos processos de construção do conhecimento. Uma transformação profunda da educação se faz necessária para que seja possível resolver os problemas da complexa realidade atual, relacionados às questões ecológicas, tecnológicas, éticas e sociais, as quais são cada vez mais preocupantes e de grandes consequências para o mundo (MORAES, 2016).

\subsection{CAMINHOS PARA A NOVA EDUCAÇÃO}

$\mathrm{Na}$ educação existe uma resistência em se incorporar novidades. É preciso saber que o novo vem para somar ao já existente, com o objetivo de atender melhor e/ou de atender diferentes finalidades. Se diferentes mídias possuem diferentes linguagens, agregase ao invés de substituir, e assim atende-se a diferentes estilos de aprendizagem e de expressão. É preciso que essa resistência seja diminuída, e que novas propostas sejam compreendidas, quanto ao que têm para oferecer e como podem ser aplicadas (CORTELAZO, 1996; SILVA, 2009).

É necessário considerar os saberes de todos os indivíduos, o diálogo como uma forma de aprendizagem, assim como toda a relação com os meios externos à escola. A bagagem cognitiva, afetiva, a história de vida e experiências singulares de cada aluno, pode ser usada em benefício do processo de ensino e aprendizagem (SILVA, 2009).

Ensinar é uma atividade colaborativa entre professores e alunos, o ensino deve também promover essa colaboração entre os alunos, estimular o trabalho em equipe e proporcionar um espaço para que os estudantes ensinem uns aos outros aquilo que dominam melhor. O processo de ensino é uma ação coletiva e compartilhada. Por meio da investigação colaborativa é possibilitado que os alunos se ajudem mutuamente na aquisição e análise de informações, permitindo também que na interpretação, as bagagens 
cognitivas, vivências e perspectivas individuais, produzam conclusões de maior riqueza (CORTELAZZO, 2000).

Ensinar também é incentivar a fazer questionamentos, a investigar e argumentar, como descreve a autora:

Ensinar é criar condições para que os alunos desenvolvam as condições básicas de domínio das diversas linguagens, fundamentalmente a da escrita, de modo a poder sistematizar o conhecimento e expressar tanto as suas dúvidas e incertezas quanto suas descobertas e criações. É, também, ajuda-los a desenvolver a reflexão, a saber fazer as perguntas certas e ir atrás das respostas adequadas. (CORTELAZZO, 2000, p. 8).

Vygotsky já dizia, contrariando as ideias vigentes na época, que a aprendizagem não era uma mera aquisição de informações, tampouco acontecia a partir da simples associação de ideias armazenadas na memória. Para Vygotsky a aprendizagem era um processo ativo, interpessoal e interno (NEVES; DAMIANI, 2006). De acordo com Freitas ${ }^{3}$ (2000 apud NEVES; DAMIANI, 2006) Vygotsky concebe o ser humano como produto de um conjunto de relações sociais. Neves e Damiani afirmam:

Quanto ao "professor vygotskyano", Freitas (2000) explica que é aquele que, detendo mais experiência, funciona intervindo e mediando a relação do aluno com o conhecimento. Ele está sempre, em seu esforço pedagógico, procurando criar Zonas de Desenvolvimento Proximal (ZDP's), isto é, atuando como elemento de intervenção, de ajuda. Na ZDP, o professor atua de forma explícita, interferindo no desenvolvimento dos alunos, provocando avanços que não ocorreriam espontaneamente. Vygotsky, dessa forma, resgata a importância da escola e do papel do professor como agentes indispensáveis do processo de ensino-aprendizagem. $\mathrm{O}$ professor pode interferir no processo de aprendizagem do aluno e contribuir para a transmissão do conhecimento acumulado historicamente pela Humanidade. É nesse sentido que as idéias de Vygotsky sobre a Educação constituem-se em uma abordagem

\footnotetext{
${ }^{3}$ FREITAS, M. T. A. As apropriações do pensamento de Vygotsky no Brasil: um tema em debate. In: Psicologia da Educação. Revista do Programa de Estudos Pós-Graduados em Psicologia da Educação. São Paulo, n.10/11: 9-28, 2000.
} 
da transmissão cultural, tanto quanto do desenvolvimento. (NEVES; DAMIANI, 2006, p. 9).

Silva (2009) demonstra como o domínio de diferentes linguagens, a cooperação no trabalho em equipe, o diálogo, o uso da criatividade, o incentivo a autonomia e a construção de conhecimento de maneira ativa, permitem aos estudantes aproveitarem novas e diferentes oportunidades, bem como construírem um conhecimento mais rico, mais profundo e mais elaborado. $\mathrm{O}$ autor demonstra o aprendizado por respeito, diálogo e ajuda mútua, o processo de ensino e aprendizagem ocorrendo por meio da troca de experiências e conversação.

A autora Moraes $^{4}$ (2004 apud SILVA, 2009) destaca a importância do ensino por meio do diálogo, considerando as bagagens cognitivas e as experiências de cada um, enfatizando a riqueza da interação para o processo de ensino e aprendizagem "É através das trocas, dos diálogos, das interações entre indivíduos que as transformações acontecem" (MORAES ${ }^{5}$, 2004, p. 255 apud SILVA, 2009, p. 65).

O autor Ferracioli (1999) em um estudo sobre Piaget, também demonstra a importância dos processos de interação para o aprendizado:

\begin{abstract}
Segundo Piaget, o conhecimento não está no sujeito - organismo, tampouco no objeto - meio, mas é decorrente das contínuas interações entre os dois. Para ele, a inteligência é relacionada com a aquisição de conhecimento à medida que sua função é estruturar as interações sujeito objeto. Assim, para Piaget, todo pensamento se origina na ação, e para se conhecer a gênese das operações intelectuais é imprescindível a observação da experiência do sujeito com o objeto. (FERRACIOLI, 1999, p. 6).
\end{abstract}

A pesquisa é de grande importância no processo de ensino e aprendizagem e na profissão do professor, o professor pesquisador continua constantemente repensando suas metodologias e buscando conhecer e entender novas formas de ensinar e novos conhecimentos, o que proporciona a melhoria da educação como enfatiza Paulo Freire:

\footnotetext{
4

${ }^{5}$ MORAES, M. C. Pensamento eco-sistêmico: educação, aprendizagem e cidadania no século XXI. 2. ed. Campinas: Vozes, 2004. $342 \mathrm{p}$
} 
Não há ensino sem pesquisa e pesquisa sem ensino. Esses que-fazeres se encontram um no corpo do outro. Enquanto ensino, continuo buscando, reprocurando. Ensino porque busco, porque indaguei, porque indago e me indago. Pesquiso para constatar, constatando, intervenho, intervindo educo e me educo. Pesquiso para conhecer o que ainda não conheço e comunicar ou anunciar a novidade. (FREIRE ${ }^{6}, 1997$, p. 32 apud GADOTTI, 2007, p. 13).

$\mathrm{Na}$ atual sociedade, onde a informação é abundante, uma sociedade de redes e movimentos, na qual existem múltiplas oportunidades de aprendizado, é essencial saber comunicar-se, pesquisar, pensar autonomamente, fazer, ter raciocínio lógico, fazer sínteses e elaborações teóricas, organizar o próprio trabalho e conhecimento, ter disciplina, ser sujeito da construção do conhecimento, estar aberto a novas aprendizagens, conhecer as fontes de informação, trabalhar colaborativamente, articular o conhecimento com a prática e com outros saberes (GADOTTI, 2007).

$\mathrm{Na}$ sociedade da informação, presente nos dias de hoje, o professor se torna um mediador do conhecimento, motivando os alunos a questionar e pesquisar, promovendo questionamentos e problematizações. $\mathrm{O}$ aluno deve ser o construtor ativo de seu conhecimento. Para que tal maneira de ensino e aprendizagem possa ocorrer, faz-se necessário que o docente também seja um professor pesquisador, com a atitude curiosa, científica e de procura por novos conhecimentos, o professor precisa carregar consigo a vontade de saber mais, de conhecer novas metodologias de ensino e construir para si novos aprendizados. O docente precisa buscar sentidos para os estudos de seus alunos, bem como encontrar sentido para suas próprias atividades, buscando ser um constante aprendiz. Gadotti descreve as características do professor para a nova educação no mundo atual:

Nesse contexto de impregnação da informação, o professor é muito mais
um mediador do conhecimento, um problematizador. O aluno precisa
construir e reconstruir o conhecimento a partir do que faz. Para isso, o
professor também precisa ser curioso, buscar sentido para o que faz e
apontar novos sentidos para o que-fazer dos seus alunos. Ele deixará de

${ }^{6}$ FREIRE, Paulo. Pedagogia da autonomia: saberes necessários à prática educativa. São Paulo: Paz e Terra, 1997. 
ser um lecionador para ser um organizador do conhecimento e da aprendizagem. Poderíamos dizer que o professor se tornou um aprendiz permanente, um construtor de sentidos, um cooperador, e, sobretudo, um organizador da aprendizagem. (GADOTTI, 2007, p. 13).

A tempestade de informações, característica da sociedade atual, leva a uma saturação informativa, é preciso recursos na educação que ensinem a organizar toda a informação recebida e transforma-la em conhecimento (CRUZ, 2008; LIMA, 2015; MORAES, 2016; POZO; CRESPO, 2009; SILVA, 2009).

$\mathrm{O}$ uso excessivo e indiscriminado das novas tecnologias tem tornado as pessoas solitárias, cada vez observa-se menos relações profundas e duradouras, menos diálogos longos e elaborados, as interações interpessoais são cada vez mais rápidas e superficiais. As redes sociais pela internet uniram pessoas ao redor de todo o mundo. Possibilitaram a comunicação instantânea entre números enormes de pessoas por todo o planeta, rompendo barreiras de tempo e espaço. Mas ao mesmo tempo, o uso em excesso desta mesma tecnologia pode causar a perda da capacidade de estabelecer relações afetivas duradouras, a perda das interações interpessoais presencialmente (SILVA, 2009).

No entanto o erro não está na existência das novas tecnologias, mas sim no mau uso das mesmas (DOWBOR, 2001; HARGREAVES, 2004; SILVA, 2009). "Nunca se esteve tão sozinho mesmo em contato com tanta gente [...]" (SILVA, 2009, p. 67).

As novas metodologias de ensino podem fazer uso destas mesmas tecnologias em benefício da educação, e podem também proporcionar espaços para a interação entre os alunos, a cooperação na aprendizagem ativa. Educando para que as novas tecnologias venham para somar no processo de ensino e aprendizagem e, não para substituir a capacidade de se relacionar com as pessoas, compartilhar vivências presencialmente e de trabalhar com colaboração (SILVA, 2009).

Hargreaves (2004) afirma que educar apenas para a sociedade da informação, também chamada de sociedade da informação e do conhecimento, pode formar uma geração sem senso de empatia, sem conscientização de sua responsabilidade para com a sociedade e o futuro desta. Indivíduos que não sabem se relacionar com as pessoas e com os sentimentos delas, que não sabem se relacionar nem sequer com seus próprios sentimentos, uma geração egocêntrica e presa ao mundo virtual e que não consegue compartilhar experiências e cooperar fora dele. 
É necessário que a educação vá além da sociedade da informação e do conhecimento, educar de maneira mais profunda, na qual o ensino desenvolve não somente a cognição, mas também a capacidade de se relacionar com as pessoas, pensar em comunidade, com empatia, interagir de maneira colaborativa. Uma educação que se da em processo de transformação na convivência, pelo diálogo e compartilhamento de ideias, linguagens e vivências, um ensino que tem seu foco no processo de aprendizagem, na comunicação e na colaboração entre alunos, bem como entre professores e alunos. Uma educação que promova a transferência para a vida social de novas atitudes e valores nas relações humanas (HARGREAVES, 2004; MORAES, 2016; SILVA, 2009).

Portanto, não é a mera utilização de tecnologias digitais que vai mudar o cenário educacional, e nem promover a melhoria do processo de ensino e aprendizagem (DOWBOR, 2001; SILVA, 2009). Como enfatiza o autor Silva:

\footnotetext{
"Maquiar" o tradicional pode fazer apenas que os mesmos erros sejam cometidos, de maneiras um pouco diferentes. Ensinar um professor como ligar e desligar um projetor, ou como programar a TV para fazer algo não o capacita para ministrar aulas com tais recursos. Apenas conhecimentos técnicos estão aquém do que é necessário. (SILVA, 2009, p. 71-72).
}

Somente introduzir novas tecnologias, em nada transforma a educação, se não for pelo estudo e preparo pedagógico para utiliza-las com uma visão didático-pedagógica inovadora, capaz de dar novos significados ao papel dos alunos e professores, promovendo uma construção ativa e colaborativa do conhecimento. A tecnologia por si só não basta, independente das virtudes que o recurso tecnológico possa oferecer, o trabalho do professor é indispensável e de extrema importância na promoção de interações sociais, na compreensão e na motivação dos alunos. A tecnologia sem a atuação adequada do professor que a utilizar, se torna apenas uma repetição de erros antigos em um novo formato, não conseguindo ultrapassar os procedimentos tradicionais de transmissão de informação. É, no entanto, uma ferramenta poderosa, quando aplicada pelo professor, que disponha de uma competência pedagógica, capaz de explorar todas as possibilidades que o recurso tecnológico tenha a oferecer (MONTEIRO, M.; GERMANO; MONTEIRO, I., 2008).

Quanto ao uso de novas tecnologias no ensino, o autor Silva (2009) afirma que o foco deve estar na aprendizagem, na construção de significado, nos objetivos da aula, as 
tecnologias devem ser escolhidas para servir as estratégias pedagógicas da aula, para servir aos propósitos da ação pedagógica e não ser o objetivo dessa ação. As tecnologias são ferramentas no processo de ensino e aprendizagem e não o centro do processo. $\mathrm{O}$ ensino deve ser centrado na aprendizagem, no aluno e nas construções de conhecimento, não na ferramenta:

Com o intuito de acompanhar a evolução tecnológica, escolas adquirem computadores, projetores, televisões de última geração, despejando-os nas salas de aula para que os professores usem-nos de alguma maneira. Sem saber muito bem o que fazer ou como fazer, os professores planejam a aula com o foco no recurso - como irei utilizar isso na minha aula? $\mathrm{O}$ mais indicado seria planejar a aula e verificar qual recurso, ou material se adéque melhor aos objetivos da aula. Talvez a pergunta mais indicada seria: Que recurso devo usar para atingir meus objetivos nessa aula? [...] O recomendável é planejar a aula e procurar saber que abordagem, tecnologia, metodologia, e materiais didáticos correspondem a seus objetivos [...] (SILVA, 2009, p. 71).

Dentre as potencialidades das novas tecnologias, quando utilizadas por uma estratégia e metodologia pedagógica adequada, objetivando o processo de ensino e aprendizagem, o autor Dowbor ressalta:

[...] a facilidade de comunicar entre escolas de uma região ou com instituições de outros países, de facilitar a comunicação entre alunos e professores por e-mail, de fazer entrevistas on-line com cientistas, tudo isto abre um gigantesco espaço de democratização e de reequilibramento social através das novas tecnologias. (DOWBOR, 2001, p. 25).

É preciso entender que no ensino é essencial a presença de uma prática social e emocional. A educação deve ser reformulada de forma que exista espaço para a criatividade, relacionamentos, interações, e imaginação, o que motiva a participação ativa dos alunos na construção de seus conhecimentos e estimula a paixão de ensinar (HARGREAVES, 2004; MORAES, 2016; SILVA, 2009).

Cortelazzo (1996) afirma que as escolas devem atuar e participar das mudanças na sociedade, promover modificações e transformações, e não serem arrastadas por essas 
mudanças, preparando os jovens para o mundo de amanhã, não para o mundo de ontem. Que o futuro da sociedade é construído hoje. E que a escola deve formar seus alunos com responsabilidade sustentável e inclusiva para o exercício da cidadania.

Quanto aos novos papeis da escola na sociedade, Dowbor afirma que:

[...] A escola pertence a um espaço, a uma comunidade. O conhecimento nas suas novas dimensões exige uma interação muito maior entre a escola e o espaço social. As novas tecnologias, ao facilitar a conectividade, podem constituir uma ponte e melhorar a integração. Numa sociedade cada vez mais individualizada, e sedenta de sociabilidade, a escola pode neste sentido desenvolver novos papeis. (DOWBOR, 2001, p. 24).

Moraes (2016) sintetiza algumas considerações importantes referentes às questões pedagógicas e metodológicas a serem aplicadas na prática docente. A autora elenca aspectos de importância a serem priorizados nos processos educativos:

- A presença de um sujeito ativo, criativo e autônomo; um sujeito auto-organizador, autoprodutor de si, ao mesmo tempo, autodeterminado em sua estrutura organizacional. É um ser humano indiviso, como expressão de uma totalidade.

- $\quad \mathrm{O}$ aprendiz como pesquisador, um sujeito capaz de compreender as diferentes dimensões de um problema sem se ater a uma única causa, um aprendiz capaz de usar diferentes fontes de informações para solucionar um problema.

- O educando é o principal artífice do seu próprio processo de formação e, em função dele, as ações devem ser planejadas.

- A existência de intercâmbios intersubjetivos, de processos reflexivos e tomadas de consciência mediante processos de autoorganização.

- $\quad$ O reconhecimento da importância do contexto, da formação contextualizada associada à tematização do cotidiano.

- A compreensão da mudança como condição intrínseca de qualquer processo de formação e de aprendizagem.

- $\quad \mathrm{O}$ reconhecimento da inscrição corporal do conhecimento, da importância do corpo como fonte de informações e de conhecimento, 
bem como o papel relevante das emoções e dos sentimentos no desenvolvimento de ações e reflexões.

- A valorização da linguagem emocional nos ambientes de aprendizagem, pois mente e corpo, pensamento e ação não estão separados das emoções, sentimentos e afetos, mas nutridos por impulsos emotivos. Assim, concordando com Maturana, subjacente a toda ação, existe sempre uma emoção.

- A educação como processo de transformação na convivência, o que requer o resgate da ética, a vivência de valores humanos, bem como do prazer em aprender.

- A possibilidade de incorporar a incerteza, o inesperado e o imprevisto nas propostas curriculares. O currículo deve estar aberto à vida, ao que acontece no mundo, no entorno e dirigido à solução criativa dos problemas.

- $\quad$ O fomento da interdisciplinaridade e da transdisciplinaridade para se poder compreender e atuar neste mundo complexo e mutante.

- A integração teoria e prática e o desenvolvimento de processos reflexivos que potencializem esta dinâmica.

- A valorização do processo, da descoberta do caminho, da experiência, da vivência do trajeto e da importância de cada momento e das circunstâncias de aprendizagem criadas, como produtos de um campo energético e vibracional que jamais se repete.

- O reconhecimento da importância das circunstâncias, dos ambientes e dos climas nos processos de aprendizagem, compreendendo que todo indivíduo é produto e produtor de suas próprias experiências, é causa e causante ao mesmo tempo, em função de sua atuação sobre as circunstâncias e retroação destas sobre ele, mediante o acoplamento estrutural que ocorre entre o sistema vivo e o meio onde está inserido.

(MORAES, 2016, p. 14-15).

Perrenoud (2001) ressalta que é necessário reconhecer que os professores não possuem apenas saberes, mas também competências profissionais que não se reduzem ao domínio dos conteúdos a serem ensinados. O autor também da ênfase da importância de que seja aceita a ideia de que a profissão muda ao longo do tempo e que sua melhora demanda atualmente que todos os docentes possuam novas competências, antes reservadas 
aos inovadores ou aos professores que precisavam lidar com públicos mais difíceis. O autor divide estas competências em dez grandes categorias:

1. Organizar e estimular situações de aprendizagem.

2. Gerar a progressão das aprendizagens.

3. Conceber e fazer com que os dispositivos de diferenciação evoluam.

4. Envolver os alunos em suas aprendizagens e no trabalho.

5. Trabalhar em equipe.

6. Participar da gestão da escola.

7. Informar e envolver os pais.

8. Utilizar as novas tecnologias.

9. Enfrentar os deveres e os dilemas éticos da profissão.

10. Gerar sua própria formação contínua.

(PERRENOUD, 2001, p. 1-2).

Monteiro M, Monteiro I e Azevedo (2010) apontam para a importância de ocorrer no curso de formação de professores a intensificação de atividades reflexivas relativas às dimensões da profissionalidade docente, as quais vão além do domínio conceitual das disciplinas que vão ensinar e das diferentes metodologias e estratégias de ensino e aprendizagem a serem aplicadas com os alunos na escola.

A escola deve buscar ser uma força de humanização, de conscientização, deve promover interações sociais. Construindo uma união entre o potencial da tecnologia e os interesses da humanidade. Em um mundo onde o conhecimento é um dos principais recursos, a educação representa uma força de mobilização e um papel de extrema importância na melhoria da sociedade (DOWBOR, 2001).

Monteiro et al. (2003) alerta que as mudanças educacionais por mero modismo pedagógico, sem uma reflexão profunda dos propósitos da mudança, sem reformulação dos valores que comunica em seus discursos, não contribui para a melhoria do cenário educacional. Por ser uma mudança sem reflexão e estudo aprofundado, não proporciona uma educação adequada para a atual sociedade. Os autores afirmam que somente por meio de um processo reflexivo, com persistência, atenção e análise crítica, a respeito do trabalho 
do professor, com o devido apoio institucional e pessoal, pode-se trazer uma contribuição eficaz para uma mudança mais significativa no ensino de ciências.

Ao rever esta literatura, conclui-se que, são necessárias novas formas de educação, mas estas devem ser construídas, escolhidas e aplicadas embasadas em pesquisas e reflexões, não por meros modismos pedagógicos ou tecnológicos. As mudanças devem ser consideradas com o objetivo da melhoria da educação, e devem vir acompanhadas do devido preparo pedagógico e técnico dos docentes. Tecnologias precisam ser escolhidas de acordo com o que elas têm a somar ao processo de ensino e aprendizagem, e utilizadas com aproveitamento de seu potencial, explorando o que uma mídia pode oferecer de diferente de outra, tendo como foco e centro a aprendizagem ativa e significativa dos alunos.

A sociedade atual, bem como o futuro da mesma, requer cidadãos conscientes, reflexivos, críticos, envolvidos, com responsabilidade sustentável e comprometidos nas situações ao seu redor e para com a melhoria da sociedade.

Para tanto a educação precisa assumir novas formas, novos conteúdos e novos papeis, em todos os seus níveis, tanto no ensino básico quanto superior, repensando inclusive as maneiras de ensino e conteúdos aplicados na formação de docentes.

O trabalho educativo deve ser repensado, transformado com o objetivo de promover as interações sociais, a colaboração, a empatia, o questionamento, a reflexão, a criatividade, a valorização dos processos criativos, a consciência em comunidade, a construção de significados, a aprendizagem com construção ativa de conhecimentos, a participação, as discussões e compartilhamento de ideias e expressões por diferentes meios de comunicação. Com a valorização das características emocionais e afetivas, proporcionando a alegria e o interesse pelo processo de ensino e aprendizagem.

É de extrema importância que este novo trabalho educacional seja desenvolvido em um panorama cooperativo, para que possa movimentar e motivar a colaboração, e ser uma força efetivamente ativa e transformadora na sociedade.

\subsection{O USO DOS JOGOS NA EDUCAÇÃO}

Saldanha e Batista (2009) ressaltam que ao longo da história da humanidade, a ludicidade está sempre presente. E que até mesmo os animais exibem o comportamento de 
brincar, em que realizam simulações de luta, sem ferir o parceiro, em um ritual no qual respeitam a norma de não morder com força e, inclusive, reconhecem a vitória de um dos participantes.

Vygotsky (2010) afirma que a ludicidade é presente, na forma de jogos e brincadeiras, em todas as culturas do mundo. É praticada por adultos e crianças, ao longo do tempo, portanto, sendo uma característica natural da humanidade, que acompanha o desenvolvimento do indivíduo e permanece nas suas diversificadas formas de atividades.

Huizinga (2008) aponta algumas características fundamentais do jogo. Segundo o autor o jogo é uma atividade voluntária, jogado dentro de determinados limites de tempo e espaço. Acompanhado de um sentimento de tensão e alegria, e da consciência de não ser visto como parte da vida real, mas justamente como uma evasão desta para um espaço fictício e conceitual, uma esfera imaginária. Segundo regras livremente consentidas, mas obrigatórias, pois quando não respeitadas, desmantelam o jogo.

No contexto das novas metodologias de ensino e das novas propostas para o cenário educacional, muitos estudos vêm demonstrando o potencial dos jogos para a educação, como Brougère (2002), que estuda as potencialidades do jogo para a educação. O autor afirma que é preciso se considerar a educação informal presente no jogo, pois o aprendizado pode ocorrer no lúdico mesmo que este não seja o seu propósito:

A ideia subjacente é que a criança aprende através de situações da vida cotidiana que nada têm a priori de educativas: conversações, passeios, televisão e espetáculos, refeições e atividades da vida cotidiana. O jogo é para ser pensado, então, não como algo isolado, mas como uma das atividades que a criança realiza no âmbito familiar, constituindo a educação familiar espontânea, trazendo socialização e também aprendizagens linguísticas, cognitivas, afetivas, etc. São as bases sobre as quais a educação mais formal será construída, assim como relações com pessoas e objetos que têm um aspecto arquétipo e que vão ser modificadas, transformadas nas atividades de educação formal, que são apenas reprises da trama da vida cotidiana em um outro contexto e com outras finalidades. A noção de educação informal gera duas ideias. Por um lado, uma continuidade entre as atividades da vida ordinária e aquelas que têm um objetivo educativo. Por outro lado, a percepção de um processo de desenvolvimento de uma educação em um contexto 
sociocultural, e jamais o simples efeito de uma maturação biológica. (BROUGÈRE, 2002, p. 12).

Os jogos podem proporcionar a exploração e a resolução de problemas, ações pertinentes a aprendizagem ativa. Brougére (2002) enfatiza que se é possível perceber que o jogo pode ser uma incitação a exploração, favorecendo, o surgimento de comportamentos com forte probabilidade educativa. E que elementos que não tem a educação como objetivo, mas sim o divertimento, como filmes, livros, jogos, teatros, dentre outros formatos de entretenimento, mantém um diálogo complexo com os elemento do mundo cotidiano, constituindo transformações e comentários desta realidade, podendo assim serem acompanhados de efeitos educativos. E esses efeitos são algumas vezes usados no contexto da educação formal, a qual recicla diversos objetos culturais, como literatura, animações, músicas e cinema, inicialmente elaborados com o propósito de entreter.

O autor complementa que o jogo, assim como os filmes e livros, se torna um espaço de aprendizagem, mesmo quando o jogador não busca no jogo o objetivo de aprender. Pois muitos jogos requerem um aprendizado anterior, que permita compreender o jogo e participar dele, e também trazem em si a manipulação de significados, a exploração, a resolução de problemas, a compreensão de diferentes linguagens. E que algumas vezes esse aprendizado pode até ser intencional pelo jogador, visando melhorar o seu desempenho no jogo:

[...] o jogo pode ser um espaço de aprendizagem em relação e esses mesmos conteúdos, mesmo se isso não é visado pelo jogador. O que caracteriza o jogo não é uma vocação particular para a educação, mas uma riqueza potencial de conteúdos culturais e de processos de construção, de transformação desses mesmos conteúdos. Como todo lazer, ele pode aparecer como uma situação complexa do ponto de vista cultural, porque instaura um espaço fictício ou mimético rico de significações culturais. Aceder ao prazer prometido pelos lazeres supõe a manipulação simbólica desses conteúdos, que pode ser acompanhada de aprendizagens informais ou implicar aprendizagens anteriores para dominar esses conteúdos. Algumas dessas aprendizagens são intencionais, ou até mesmo formalizadas. É o caso de alguns jogadores no esporte, nos jogos de reflexão ou nos jogos eletrônicos que desenvolvem 
aprendizagens paralelamente para melhorar seus desempenhos ao jogar. (BROUGÈRE, 2002, p. 16).

Os jogos eletrônicos, videogames, apresentam elevado potencial para a educação, como foi demonstrado no trabalho de Dias, Novaes e Rosalen (2015), no qual foi verificado que a aplicação de um jogo de videogame na disciplina de ciências proporcionou melhora do aprendizado, melhor memorização, ganhos cognitivos, de relação interpessoal, desenvolvimento de comunicação, resultando na melhoria da aprendizagem em ciências. Neste estudo foi constatado que os alunos participavam com grande entusiasmo da atividade, devido a ligações emocionais positivas que eles tinham com o jogo, e que o uso do jogo eletrônico como estratégia de ensino e aprendizagem pode proporcionar aprendizagem significativa aos estudantes. Também foi percebido maior interação entre os estudantes e melhoria da autoestima, mostrando potencial dos jogos no desenvolvimento emocional e social:

O jogo Minecraft ${ }^{7}$ foi utilizado como estratégia de ensino e aprendizagem, propiciando a consolidação das memórias, despertando a atenção dos estudantes, estimulando seu interesse, conectando os conteúdos às associações pessoais de cada estudante e levando a uma aprendizagem significativa. $\mathrm{O}$ estudantes puderam realizar diversas associações que são a base da memória, e quanto mais associações relacionadas a uma informação, mais fácil resgatá-las no futuro [...] constatou-se que houve uma melhora na evocação das memórias de conteúdos. [...] os estudantes sentiam-se mais seguros para se expressar em sala de aula, tanto com o professor quanto com os colegas. Foi observado ainda, que os estudantes que tinham mais habilidades com o jogo, estreitavam relações com outros colegas de maneira a ajuda-los, se comunicando com alunos que nem ao menos tinham conversado em sala de aula durante o período letivo. Essa mudança e a estabilidade na personalidade e nos relacionamentos sociais constituem junto com o desenvolvimento psicossocial, o qual pode influenciar o funcionamento cognitivo, e influenciavam também a memória que a todo momento

\footnotetext{
${ }^{7}$ Minecraft é um jogo eletrônico de mundo aberto que permite a construção usando blocos (cubos) dos quais o mundo é feito. Foi criado por Markus Persson.
} 
estava sendo modulada por emoções e pelo estado de ânimo dos estudantes. (DIAS; NOVAES; ROSALEN, 2015, p. 12-13).

Os jogos eletrônicos, como os jogos de computador e videogame, são de grande atratividade, devido à satisfação de desejos, competição, superação de desafios e descontração. No contexto educativo os jogos promovem o exercício de habilidades cognitivas importantes para a aprendizagem, além de promover o aprimoramento de atitudes que contribuem com a formação dos alunos. Determinadas características dos jogos permitem a elaboração de atividades pedagógicas. Características como a contextualização de conteúdos, privilegiando a relação entre os mesmos e considerando os conhecimentos prévios dos alunos. A proposição de problemas, os quais motivam os alunos a buscarem novos conhecimentos para levantarem hipóteses de solução. A valorização da autonomia, criando a possibilidade de definir trajetórias próprias para a realização das atividades, a interação social e o exercício da pesquisa. Portanto, os campos, da educação, que privilegia a aprendizagem, e dos jogos, que privilegia o entretenimento, podem ser aproximados e combinados, proporcionando alternativas pedagógicas mais motivadoras aos alunos (RAMOS, 2015).

A valorização da autonomia, a qual pode ser proporcionada por meio dos jogos, traz diversos benefícios para a aprendizagem. No estudo de Reeve (2009) é demonstrado que quando os professores adotam um estilo de ensino que incentiva e proporciona autonomia, os resultados são muito benéficos para a aprendizagem dos alunos, e também para o bem estar tanto dos alunos, quanto dos professores. Quando a autonomia é incentivada e proporcionada nas estratégias pedagógicas, todo o processo de ensino e aprendizagem é beneficiado, proporcionando um ensino de melhor qualidade.

Gamberini et al. (2008) realizou em seu estudo uma revisão das pesquisas existentes sobre o uso de jogos de computador e videogame, no contexto da saúde, demonstrando que estes jogos, devido a suas potencialidades, têm sido explorados com êxito nesta área. $\mathrm{O}$ estudo revisou pesquisas em que os jogos foram explorados para a prevenção, apoio, treinamento e reabilitação, particularmente, enfatizando a relação entre os processos cognitivos e o jogo, demonstrando que os jogos eletrônicos fomentam a motivação e melhoram os processos cognitivos.

O divertimento constitui um forte potencial educativo informal, outros fatores do cotidiano também podem produzir efeitos educativos informais, tal como a utilização de 
um objeto técnico (RABARDEL ${ }^{8}, 1995$ apud BROUGÈRE, 2002, p. 16). Brougère (2002) enfatiza que os lazeres ou jogos tecnológicos, em particular os jogos eletrônicos, podem acumular os efeitos de aprendizagem próprios de sua dupla característica, jogo e objeto tecnológico. $\mathrm{O}$ autor destaca que alguns jovens adultos aprenderam uma atividade profissional ligada a informática em um contexto de lazer lúdico.

A ludicidade, além de melhorar a aprendizagem, contribuir com as interações entre alunos e entre professores e alunos, pode atender as diferenças, proporcionando uma educação inclusiva (JULIANI; PAINI, 2008).

Os jogos podem possibilitar a aprendizagem ativa, investigativa, por meio da resolução de problemas, do trabalho colaborativo e da simulação de situações, proporcionando a autorreflexão, a participação, a interação social e o ensino significativo, além de incentivar a criatividade (OLIVEIRA; RIBEIRO, 2012; RANDI; CARVALHO, 2013; REZENDE; COELHO, 2009; SOARES et al., 2016; SUNG; HWANG, 2013).

Marin et al. (2010) afirmam que as metodologias ativas estimulam o estudo constante, a independência e a responsabilidade, possibilitam a integração das dimensões biopsicossociais, preparam para o trabalho em equipe. Os autores também ressaltam que a construção de novos modelos de aprendizagem requer constante empenho, objetivando o seu aperfeiçoamento.

O uso de jogos na escola pode inclusive melhorar o comportamento dos alunos, motivando-os a fazer as atividades com mais interesse, também gerando maior sentimento de segurança nos estudantes no momento de realizar atividades em sala de aula (BARBOSA; CARVALHO, 2008).

Os jogos apresentam grande potencial educativo, independente se é um jogo de tabuleiro ou cartas, ou algum tipo de brincadeira, ou até mesmo jogos eletrônicos, toda forma de ludicidade pode ser explorada no ambiente escolar, de diferentes formas, buscando a melhoria da educação. Pesquisas e estudos com essa temática são muito importantes no campo das novas metodologias de ensino.

Dentro deste contexto, um determinado tipo de jogo têm se destacado nas pesquisas, devido às suas características tem apresentado diversas possibilidades para o cenário educacional, este jogo é o Role-Play Game.

\footnotetext{
${ }^{8}$ Rabardel, P. Les hommes et lês Technologies - Approche cognitive dês instruments contemporains. Paris: Armand Colin, 1995.
} 


\subsection{UMA BREVE EXPLICAÇÃO SOBRE ROLE-PLAYING GAME}

Role-Playing Game, geralmente traduzido como Jogo de Interpretação de Papéis, ou Jogo de Interpretação de Personagens, mais conhecido pela sigla RPG, consiste em um jogo de contar histórias. O RPG é um jogo no qual os jogadores interpretam personagens, criados pelos próprios jogadores, imersos em um universo de ficção. Esse universo, geralmente chamado de cenário, é descrito e pode inclusive ser criado, por um dos jogadores, denominado como mestre. O jogador que assume a função do mestre em uma partida de RPG tem o papel de propor e narrar a aventura, construindo a atmosfera do jogo, além de conduzir a história na qual os personagens dos outros jogadores irão agir. Juntos o mestre e demais jogadores contam uma história, pois a história descrita pelo mestre vai tomando diferentes rumos dependendo das escolhas jogadores, que decidem e descrevem as ações que seus personagens fazem na aventura em que estão imersos. Aventura é o nome que geralmente é dado para toda essa atividade por meio da qual a trama é contada (BETTOCCHI; KLIMICK, 2003; BOLZAN, 2003; FAIRCHILD, 2004; RODRIGUES, 2004; ROSA, 2004; SILVA, 2009).

Os encontros entre os jogadores nos quais se joga RPG são chamados de partidas, ou sessões. A sucessão de partidas nas quais a trama continua com os mesmos personagens, como episódios de uma série, recebe o nome de campanha (FAIRCHILD, 2004; RODRIGUES, 2004; SILVA, 2009).

O jogo de interpretação de papéis apresenta regras, para que as ações dos personagens sejam coerentes com o universo no qual a história se passa. Uma aventura de RPG lembra uma brincadeira de faz de conta, porém com um sistema de regras para normatizar a brincadeira, garantindo que a imaginação de um jogador não ocupe o espaço da imaginação do outro, possibilitando que todos os jogadores possam ter uma participação ativa na aventura. Estas normas podem ser simples, ou complexas, dependendo do sistema de regras escolhido pelos jogadores. As regras em uma aventura de role-playing game além de manterem a coerência na aventura, também auxiliam em manter o fator dificuldade no jogo, o desafio, o que estimula a elaboração de estratégias e ações cooperativas entre os jogadores (SILVA, 2009).

Uma ação em uma partida de RPG, nas quais as regras se aplicam, seria, por exemplo, um jogador que interpreta uma personagem arqueiro, esta personagem quer 
disparar uma flecha em um alvo em movimento que está a uma grande distância. O jogador poderá realizar um teste, que em muitos sistemas de regras de RPG funciona por meio do lançamento de dados de várias faces, diferentes dos dados comuns de seis faces, embora também existam sistemas de regras que utilizam apenas dados de seis faces. Este teste apresentará uma determinada dificuldade específica para aquela situação, estipulada pelo mestre. Esta dificuldade também é fundamentada no próprio sistema de regras do jogo, levando em conta a habilidade desta personagem com o arco e flecha, como está o emocional da personagem naquele momento, as características desta personagem, criadas pelo próprio jogador que a interpreta, bem como diversas outras variáveis da situação em questão, como velocidade do alvo, distância do alvo até o arqueiro, presença ou ausência de vento, força de tensão aplicada no arco, obstáculos presentes na direção na qual a flecha será disparada e etc.

Se o jogador for bem sucedido no teste, por exemplo, obter um valor alto no lance de dados, sua personagem irá acertar a flecha no alvo. Se o jogador falhar no teste, obter um valor baixo no lance de dados, essa flecha irá errar o alvo. Portanto, na situação descrita acima, as regras do role-playing game permitem aos jogadores saberem se essa flecha imaginária acertou ou não o alvo, igualmente imaginário.

Sem as regras seria difícil saber a trajetória desta flecha, pois trata-se de uma flecha e um alvo, ambos imaginários, assim como toda a ação descrita pelo mestre e pelos demais jogadores durante a aventura (SILVA, 2009).

O conceito de um jogo de RPG pode ser entendido da seguinte forma, como explica a autora Rodrigues:

O Roleplaying Game é um jogo de produzir ficção. Uma aventura é proposta por um narrador principal - o mestre - e interpretada por um grupo de jogadores. A ação pode se passar em vários "mundos": de fantasia medieval, terror ou futurista. Pode também interagir com um universo ficcional preexistente. As regras do RPG são as da narrativa. A construção de personagens, o detalhamento do cenário, os "ganchos" do enredo são encontrados nas narrativas orais dos jogadores de RPG, mas foram, antes, colocados em cena por autores dos mais diferentes gêneros de narrativa. Mistura o "faz-de-conta" com o velho hábito de contar histórias, entrelaçando a literatura com o roteiro de televisão e cinema, o 
jogo mobiliza milhares de jovens, produzindo aventuras verbalmente, que, para serem contadas, podem levar dias, semanas e meses.

Crianças, adolescentes e adultos reúnem-se em torno de um "mestre" que preparar uma aventura com o auxílio de livro de regras. Os jogadores são atores e, ao mesmo tempo, roteiristas da ficção produzida em grupo. É um jogo onde não existem vencedores entre os que jogam. Os derrotados, quando existem, são uma necessidade do enredo. (RODRIGUES, 2004, p. 18).

Embora o role-playing game possa se assemelhar com jogos de tabuleiros, por fazer uso de dados, lápis, papel e borracha e pode também usar tabuleiros, livros e miniaturas. Ele se difere de outros jogos devido à interpretação de personagens e por não apresentar vencedores e perdedores. Todos os jogadores colaboram entre si para realizarem os feitos na história que está sendo contada. E mesmo se os objetivos da aventura não forem atingidos, ainda assim a história continua, com os eventos que se desencadeiam a partir dos resultados da aventura, sejam esses quais forem. Desta forma, as atitudes das personagens no jogo determinam o rumo da história que está sendo contada, pois as consequências destas ações realizadas pelas personagens ocorrem no universo no qual a campanha se passa, e as aventuras continuam com as tramas decorrentes destas ações (BOLZAN, 2003; RODRIGUES, 2004; SILVA, 2009).

Quanto a criação de personagens pelos jogadores a autora Rodrigues afirma:

O jogador assume a identidade de uma personagem e finge sê-la durante o desenrolar da aventura. Esta personagem é construída, elaborada numa ficha, de forma detalhada, trabalhosa, como detalhado e trabalhoso é o caminho da criação. (RODRIGUES, 2004, p. 19).

A autora complementa sobre a riqueza de detalhes que pode ser explorada na criação e interpretação das personagens, sobre o fato de no processo de criação das personagens o jogador conceber pontos fortes e pontos fracos a sua personagem, de forma que as personagens sejam mais humanas, ainda que possam ser criaturas fantásticas não humanas, dependendo do cenário do jogo, as características complexas das emoções estão presentes nestas personagens. Não sendo, portanto, personagens unidimensionais e simplistas: 
As fichas de personagens elaboradas pelos jogadores são decisivas para o desenvolvimento da narrativa. As personagens não são construídas de forma maniqueísta. Elas apresentam qualidades e defeitos, vantagens e desvantagens. O item Desvantagens "afina" especialmente o jogo, torna-o mais complexo, permitindo que se explore minuciosamente o conjunto de características de uma personagem inteira. (RODRIGUES, 2004, p. 19).

No RPG a pesquisa é um elemento constantemente presente, seja quando os jogadores fazem pesquisas sobre os tipos de personagens que podem criar, o cenário da história, para que criem um personagem coerente a este cenário, ou quando pesquisam as regras em um livro de regras no momento da construção de sua personagem, ou mesmo durante as partidas na hora de decidir uma ação a ser tomada. Ou quando o jogador mestre está preparando as aventuras, em que se faz necessário muita pesquisa a respeito do cenário a ser jogado, regras, personagens, vilões e aliados que podem aparecer na trama e dos caminhos da narrativa. O mestre deve estar bem preparado, e ter criatividade para, além de seus roteiros e planejamentos, também saber improvisar, pois os jogadores podem realizar escolhas e ações que ele não havia previsto no roteiro, mas terá de ser capaz de manter a narrativa coerente e a trama interessante mesmo assim (BOLZAN, 2003; RODRIGUES, 2004; SILVA, 2009).

Quanto ao papel desempenhado pelo jogador mestre, Rodrigues afirma:

O mestre do jogo - sempre autodidata, porque não existem cursos para formar ficcionistas de RPG - é alguém que lê livros de regras, pesquisa o cenário em que a aventura vai se desenvolver, as personagens, os possíveis antagonistas ou aliados, os caminhos que a narrativa pode seguir no cenário e nas condições propostas. A pesquisa feita pelo mestre tem de ser bem cuidada. Ele precisa ser ágil para calcular, durante o jogo, as possibilidades de desenvolvimento da narrativa, torná-la atraente para outros jogadores, interagir com eles, responder a suas ações, garantir que a coerência da história seja mantida. Na verdade, o mestre de RPG é o narrador principal e o diretor de cena. A ficção produzida em grupo, de forma interativa, é verbalizada, uma mistura de narrativa oral e teatro do improviso. [...] (RODRIGUES, 2004, p. 19). 
Ao se iniciar uma campanha de role-playing game os jogadores precisam entender como é o cenário no qual a história do jogo se desenvolve. Precisam buscar conhecer a temática da trama, a qual é apresentada pelo jogador mestre. Então, cada jogador cria sua personagem coerente com o cenário no qual a trama do jogo irá ocorrer, descrevendo as características e a história desta personagem (RODRIGUES, 2004; SILVA, 2009).

O mestre deve preparar as aventuras, escrevê-las buscando criar uma narrativa envolvente, propor desafios e escolhas interessantes pelas quais irão passar os outros jogadores. O mestre também cria todas as personagens com que os personagens jogadores irão interagir durante a aventura. Estas personagens, que podem ser, ou não, antagônicos aos dos jogadores, serão interpretados pelo mestre ao longo das partidas e, por isso, são chamadas no role-playing game de NPC, sigla que significa Non-Player Character, comumente traduzido como personagem não jogador, ou personagem não jogável (BOLZAN, 2003; RODRIGUES, 2004; SILVA, 2009).

O role-playing game apresenta todas as características fundamentais do jogo apontadas por Huizinga (2008), as quais foram citadas no tópico anterior (é uma atividade voluntária, dentro de determinados limites de tempo e espaço, acompanhado de um sentimento de tensão e alegria, e da consciência de não ser visto como parte da vida real, mas exatamente como uma evasão desta para um espaço fictício e conceitual, um campo imaginário, seguindo regras, livremente consentidas, mas obrigatórias, pois quando não respeitadas, estragam o jogo). Portanto, o role-playing game é um jogo em seu pleno significado.

O RPG é um jogo que demanda muita comunicação verbal, imaginação e cooperação. Todas as ações dos personagens no jogo ocorrem na imaginação dos jogadores. Os jogadores de role-playing game geralmente se reúnem ao redor de uma mesa para jogar, ou até mesmo no chão. Como citado anteriormente neste tópico, este jogo pode usar tabuleiros e miniaturas. E também pode ocorrer a utilização de mapas e desenhos. No entanto os únicos elementos realmente necessários são, papel, lápis e borracha, para se escrever as fichas dos personagens e realizar anotações, um sistema de regras, geralmente presente na forma de um livro de regras (existem diversos livros com sistemas de regras de RPG disponíveis no mercado), e os dados para criar os eventos aleatórios na trama do jogo (KLIMICK ${ }^{9}, 1992$ apud BOLZAN, 2003; SILVA, 2009).

\footnotetext{
${ }^{9}$ KLIMICK, C. Revista Dragão Brasil, Rio de Janeiro, n.64, 1992.
} 
Sobre as ações dos jogadores, durante uma partida de role-playing game, e o verdadeiro objetivo deste jogo, pode-se concordar com Bolzan (2003), que descreve:

É um jogo de interpretação, mas os jogadores não representam, pelo
menos não no sentido teatral. É raro acontecer de alguém se levantar e
começar a agir e se movimentar como se fosse o personagem; isto ocorre
apenas em alguns momentos para melhor ilustrar a cena. Esta
representação é verbal, se aproximando de uma leitura de texto (como a
que antecede os ensaios no palco), mas sem texto. O objetivo do jogo não
é ganhar (uma vital diferença dos outros jogos), mas completar uma
história. Nem sempre o obstáculo apresentado pelo mestre é superado, ou
o objetivo apresentado por ele é alcançado, mas o personagem continua
lá, ele está vivo. É como na vida, ela continua, ele poderá tentar de novo
ou partir para outra aventura. [...] a interpretação é a base do RPG, e
quanto mais os jogadores se valerem dela, mais rica será sua experiência (BOLZAN, 2003, p.141-142).

Concluindo, os jogadores de RPG se reúnem, interagem, dialogam, criam personagens e histórias, interpretam personagens, elaboram estratégias e cooperam entre si para alcançarem o objetivo principal deste jogo: se divertirem ao contarem uma boa história, uma história interessante, com personagens cativantes e bem elaboradas e com um roteiro emocionante.

\subsection{O USO DO ROLE-PLAYING GAME NA EDUCAÇÃO}

Ao se analisar o role-playing game, pode-se dizer que o processo pelo qual um jogador mestre passa ao preparar as aventuras, se assemelha ao processo pelo qual um professor prepara as suas aulas. Os jogadores, assim como os alunos em uma sala de aula, devem participar ativamente da solução de problemas, interagindo entre si em equipes cooperativas para alcançarem um objetivo comum a todos, sendo mediados pelo mestre, que, assim como o professor em sala de aula, propõe o problema a ser solucionado. 
O potencial do RPG como ferramenta pedagógica fica claro na observação feita por Rodrigues:

No Roleplaying Game, milhares de jovens repetem a experiência de Lobato, muitos sem jamais o terem lido. Apropriam-se de histórias narradas por livros, filmes, quadrinhos e as reinventam em grupo. (RODRIGUES, 2004, p.19).

O jogo de interpretação de personagens pode ser mais uma forma de promover interatividade na escola, aumentando a participação dos alunos no ensino. $\mathrm{O}$ aluno pode aprender ao mesmo tempo em que vai utilizando o que está sendo aprendido na forma das ações de seu personagem no jogo. O RPG pode ser uma ferramenta que permite evidenciar a aplicabilidade dos conteúdos. É possível adaptar determinados sistemas de regras para o uso em sala de aula (KLIMICK ${ }^{10}, 1992$ apud BOLZAN, 2003).

Dependendo do cenário no qual a história do jogo acontece, pode haver neste enredo determinada violência, heróis e vilões em combate, ou dependendo da temática escolhida, até mesmo algum período ou acontecimento violento da história da humanidade. Portanto, quando se busca a utilização do RPG na escola, é imprescindível que o professor planeje muito bem a ambientação do jogo, o roteiro da história e os elementos da aventura, de acordo com as características de seus alunos, como faixa etária, linguagem e cultura (MARCATTO $^{11}, 1996$ apud BOLZAN, 2003).

Quanto a esta questão da violência na fantasia, que pode estar presente no RPG assim como em jogos eletrônicos, filmes, animações, jogos de tabuleiros e brinquedos. É muito pertinente citar Jones (2004), autor do livro Brincando de Matar Monstros, que enfatiza a necessidade e importância da fantasia do jovem, e da criança, para o seu desenvolvimento. $\mathrm{O}$ autor explica que quando um adulto permite que a fantasia da criança, provoque nele, reações que estariam apropriadas à realidade, este adulto interfere negativamente no aprendizado da criança a respeito de entender a diferença entre a fantasia e a realidade.

O uso de um exemplo pode facilitar a compreensão deste apontamento feito por Jones (2004):

\footnotetext{
${ }^{10}$ KLIMICK, C. Revista Dragão Brasil, Rio de Janeiro, n.64, 1992

${ }^{11}$ MARCATTO, A. Saindo do quadro. São Paulo: Marcatto, 1996
} 
Duas crianças estão brincando de Star Wars, uma delas está se imaginando como Darth Vader, fazendo o papel do vilão da história, combatendo o herói Luke Skywalker, que está sendo representado pela outra criança, fazendo o papel do bem, do herói da história que irá salvar a galáxia. Eles estão reproduzindo a cena que eles assistiram em Star Wars Episódio V O Império Contra Ataca, ${ }^{12}$ na qual Vader e Luke se confrontam com seus sabres de luz em uma ponte estreita, até que chega o clímax da cena onde o vilão derrota o herói, que tem sua mão cortada rapidamente pelo sabre de luz de Darth Vader. Após um intenso diálogo, onde uma grande revelação acontece na história, Luke consegue escapar com vida, mas derrotado.

As crianças vêm essa brincadeira como uma fantasia inofensiva, estão brincando, imersas em seu espaço seguro, estão encenando personagens que se tornaram especiais para elas, devido as emoções que desenvolveram ao assistir aos filmes. A criança que hoje está fazendo o papel de Darth Vader, outro dia, estará fazendo o papel de Luke Skywalker, e vice e versa. Ela está brincando de assumir diversos papeis em suas aventuras de faz de conta, e com isso se desenvolvendo. Pode-se concordar com Jones que afirma:

Para que possam desenvolver uma personalidade que lhes será útil durante toda a vida, os jovens precisam de modelo, orientação, direcionamento, comunicação e limites. Mas também precisam de fantasia, de brincadeira e se deixar levar pelas histórias. É assim que reorganizam seu mundo em formas que possam manipular. É assim que exploram seus próprios sentimentos e emoções, e assumem o controle sobre si. É assim que matam seus monstros (JONES, 2004, p. 66).

Sobre esta afirmação de Jones (2004), Vieira (2012), faz o seguinte apontamento:

Quer dizer, proibir um jovem de fantasiar suas agressividades, censurar práticas que envolvam violência imaginária e irreal e que sejam do consentimento dos jovens pode gerar mais que um conflito interno nos pais, pode gerar uma etapa do desenvolvimento do jovem não resolvida: ele não matou seus “monstros”! (VIEIRA, 2012, p. 39).

\footnotetext{
${ }^{12}$ Star Wars é uma franquia de aventura/ficção científica, criada pelo cineasta George Lucas. Luke Skywalker e Darth Vader são personagens pertencentes à franquia Star Wars.
} 
Retomando o exemplo das crianças brincando de Star Wars, mencionado anteriormente, se naquele momento da brincadeira um adulto chegar, falando com seus filhos com tom de repreensão, devido a sua ansiedade, receio de ver seus filhos brincando de faz de conta em um contexto imaginário violento, como o confronto de sabres de luz entre Darth Vader e Luke Skywalker. E este adulto advertir seus filhos dizendo por exemplo: "Não façam isso! É errado cortar a mão das pessoas!". Sendo que toda a ação do duelo fazia parte da brincadeira de faz de conta das crianças, a criança que estava no papel do herói, simulava, imaginava, ter tido a mão cortada.

Segundo Jones (2004), observa-se que este adulto estará atrapalhando o processo mental destas crianças de separar a fantasia da realidade. Pois a imaginação, antes inocente e prazerosa para as crianças, de repente tornou-se perigosa, ao ponto de causar uma reação de espanto no adulto. $\mathrm{O}$ espaço seguro no qual a criança fantasiava em sua brincadeira de faz de conta, agora não parece mais tão seguro, pois esta atitude do adulto, fez com que a criança agora pense que sua imaginação é perigosa e errada.

$\mathrm{O}$ autor Jones enfatiza o efeito negativo, causado na criança, por reações deste tipo manifestadas pelos adultos, com relação as brincadeiras de fantasia da criança:

[...] deixamos vagos os limites que ela [a criança] está tentando estabelecer. Ensinamos-lhe que tiroteios de mentirinha fazem com que os adultos se sintam ameaçados na realidade e, portanto, suas próprias fantasias devem ser mais perigosas e mais poderosas do que pensavam. $\mathrm{O}$ resultado para a criança é mais ansiedade e dúvida em relação a si mesma, mais preocupação a respeito do poder dos pensamentos violentos, menos sensação de controle sobre seus próprios sentimentos e menos prática em expressar suas fantasias - uma combinação bem mais capaz de levar tanto a problemas de comportamento quanto a timidez excessiva, se comparada ao seu divertimento seguro. (JONES, 2004, p. 61).

O autor aponta a importância das histórias para as crianças, a importância da ficção, dos mitos, das narrativas sobre a luta do bem contra o mal, dos feitos dos heróis e vilões. Afirmando que:

[...] quanto mais tempo eu passo envolvido com o ato de contar histórias, mais certeza tenho de que a função principal de uma história é seu significado emocional. O que mais interessa para o desenvolvimento 
infantil é a conexão emocional que a criança faz entre a fantasia e a maneira pela qual a trabalha, por meio da brincadeira e da imaginação, dentro de sua vida emocional. Esse é o poder do símbolo, do mito e da metáfora. (JONES, 2004, p. 61).

$\mathrm{O}$ role-playing game possibilita ao jovem a oportunidade de interpretar diversas personagens, de ter outros papéis sociais, outras responsabilidades, mesmo no âmbito do imaginário, essa oportunidade consiste em um interessante potencial educacional (SILVA, 2009). Pois além de contribuir com o desenvolvimento dos jovens, o RPG pode ser usado como uma ferramenta educacional de simulação. Permitindo simulações de situações com grupos pequenos de alunos, ou até mesmo com uma sala de aula inteira (CAMARGO, 2006).

Ao se fazer um levantamento bibliográfico a respeito das pesquisas sore o uso do RPG na educação, percebe-se que o role-playing game pode ser utilizado como estratégia educacional, de diversas maneiras diferentes, tanto no Ensino Fundamental e Médio, quanto no Ensino Superior, portanto, abrangendo também a formação de professores (AMARAL; BASTOS, 2011; ANDRADE; CARNEIRO, 2007; BOLZAN, 2003; CAVALCANTI; SOARES, 2009; COSTA; LIMA; ALMEIDA, 2011; FERREIRA, J. et al., 2007; FERREIRA, C. et al., 2007; LOPES; KLIMICK; CASANOVA, 2003; OLIVEIRA, A.; RIBEIRO, 2012; OLIVEIRA, R.; PIERSON; ZUIN, 2009; RANDI; CARVALHO, 2013; REZENDE; COELHO, 2009; RODRIGUES, 2004; ROSA, 2004, 2012; SILVA, 2009; SOARES, A. et al., 2015, 2016).

No entanto, Fairchild (2004) faz um alerta sobre o discurso da escolarização do role-playing game, apontando que é necessário muita pesquisa sobre quais maneiras o RPG pode ser utilizado na prática escolar. $\mathrm{O}$ autor alerta para o cuidado que se deve ter no discurso da escolarização do RPG, quanto à premissa de que as maneiras de dar aula que ignorem um determinado repertório artístico, temático ou lúdico, não podem ser divertidas e nem despertar o desejo no aluno pelo conhecimento e, o prazer pelo aprendizado. Podese concordar com o autor que:

[...] Segue-se que a resolução de um problema matemático ou o estudo de uma obra literária não poderia se dar a não ser por obrigação, pois desrespeitaria desde inicio a suposta subjetividade do aluno. Com tudo, no entanto, esquece-se que, se o jogo permite à criança exercitar 
simbolicamente sua inserção no mundo, resolver um problema de física também insere o aluno, de uma maneira diferente, na sociedade, e não deixa de ser, portanto, uma prática que pode contar com seu desejo (FAIRCHILD, 2004, p. 154).

O autor afirma que o professor não precisa ser RPGista (denominação atribuída aos jogadores de RPG) para ser capaz de ensinar e promover uma construção ativa do conhecimento para seus alunos. Afirmando que é preciso combater premissas como a de que somente por meio do jogo, do RPG ou de qualquer recurso artístico e lúdico, que um professor consegue proporcionar um ensino de qualidade, com significado, participação ativa de seus alunos, construção de conhecimento e valores. Fairchild (2004), alerta sobre a questão da autoria do professor sobre a sua aula, afirmando que o professor se apropriar da proposta metodológica de terceiros, pode não ter bons resultados. Que melhor seria o professor ser o autor de sua própria proposta metodológica:

[...] parece-nos malfadada a maneira como o discurso prevê a participação do professor na implementação do RPG. É preciso deixar de vê-lo como um sujeito em falta, deficitário de um saber restrito ao domínio de outros, e admiti-lo como possível autor nesse processo - caso contrário, corre-se o risco de implodir o edifício pela própria base. (FAIRCHILD, 2004, p. 156).

O autor também afirma, que a maioria dos materiais produzidos com metodologias e atividades para professores aplicarem o RPG em sua aula, são versões simplificadas e facilitadas do RPG, e que muitas vezes podem não estar de acordo com a proposta pedagógica que o professor pretende cumprir. Fairchild questiona porque o professor não pode se apropriar do conhecimento do RPG em sua forma padrão, sem adaptações e facilitações, se tornando um professor RPGista, se tornando autor de suas metodologias e atividades dentro do contexto da utilização do RPG no ensino:

[...] Não parece haver motivo para que se adapte o RPG ao professor. Não há razão para que ele não aprenda a jogar o RPG “comum”, como todos os demais RPGistas. De fato o único professor autorizado a produzir discurso sobre o RPG é aquele que se pode considerar também RPGista. (FAIRCHILD, 2004, p. 156). 
De acordo com Fairchild (2004) a oportunidade aberta ao uso do RPG na educação, está na possibilidade de que por meio dele se possam criar atividades que levem os alunos a realizar operações, e apropriações de conhecimentos e capacidades, que outros recursos não propiciariam com a mesma eficácia, desta maneira sim levando à inovação.

A autora Rodrigues (2004), autora que também escreveu a primeira Tese de Doutorado no Brasil sobre role-playing game, fez uma análise em seu livro a respeito do aspecto literário dos jogos de RPG mais conhecidos no Brasil, bem como também das potencialidades pedagógicas do uso do RPG na formação de alunos e professores, e no auxílio à formação de leitores e escritores.

Na pesquisa de Saldanha e Batista (2009) foi identificado que o RPG é percebido pelos jogadores como um teatro improvisado, uma forma de lazer, uma terapia, uma projeção de personalidade, um facilitador das relações pessoais e como uma confraternização entre amigos. Foi determinado também que o principal fator motivacional dos jogadores era a amizade, a vontade de estar com os companheiros de jogo.

Pesquisas demonstram que o ato de jogar RPG desenvolve e motiva a criatividade (CHUNG, 2013; DYSON et al., 2015; KARWOSKI; SOSZYNSKI, 2008). Bolzan (2003) também constatou que o RPG aplicado a educação pode desenvolver a criatividade, envolver os alunos na atividade, sendo portanto motivador, além de ser interdisciplinar, fomentar nos jogadores o comportamento de pesquisar, na hora da construção de personagens, bem como a cooperação em conjunto com a pesquisa na hora de resolverem os problemas da aventura. A autora afirma que o RPG apresenta uma metodologia construtivista de resolução de problemas, e que uma nova metodologia para a sala de aula pode ser construída utilizando o RPG, seja em atividades presenciais, a distância ou virtuais.

A pesquisa de Araujo, Oliveira e Cemi (2011) demonstrou a utilidade do RPG no tratamento e prevenção da dependência de drogas na adolescência.

$\mathrm{O}$ role-playing game promove entusiasmo nos alunos em participar, fazendo com que a escola se torne um ambiente prazeroso para os estudantes, além de auxiliar na compreensão de conteúdos disciplinares, proporcionar aplicabilidade dos conhecimentos construídos e estimular a criar, pensar, socializar e interagir (KLIMICK; BETTOCCHI; REZENDE, 2012). 
Por meio das partidas de RPG o aprendizado pode ocorrer pela Zona de Desenvolvimento Proximal, definida por Vygotsky (SHMIT; MARTINS, 2011). O RPG também pode colaborar com o processo de ensino e aprendizagem a partir da teoria de Piaget, pois por meio deste jogo é possível causar a desestruturação do esquema cognitivo dos alunos, eles buscarão recuperar o equilíbrio cognitivo, assimilando e acomodando o novo aprendizado (ZACCAGNINO ${ }^{13}, 2006$ apud SILVA, 2009, p. 52).

O RPG promove a autonomia dos alunos na pesquisa e na construção de seu conhecimento, além de motivar cooperatividade, proporcionar a ludicidade durante a aprendizagem e é eficiente como recurso didático que atenda às especificidades e heterogeneidade dos alunos em uma mesma sala de aula e é uma ferramenta motivadora e fomentadora de interação entre os alunos (AMARAL; BASTOS, 2011).

Quanto ao uso do role-playing game no ensino de ciências, o jogo foi verificado como uma excelente estratégia de avaliação na pesquisa de Cavalcanti e Soares M. (2009) que pesquisou o uso do RPG no ensino de química. Os autores afirmam que as vantagens do uso do RPG no ensino de ciências está relacionado a liberdade de ação, trabalho em grupo, cooperação e construção conjunta do conhecimento.

No trabalho de Oliveira A. e Ribeiro (2012) foi elaborado um RPG educativo com alunos do curso de biologia. Posteriormente esse RPG educativo foi aplicado com alunos do ensino fundamental e médio, no contexto do ensino dos processos digestivos. Os resultados foram positivos, e o jogo se mostrou uma eficiente ferramenta para o ensino. Os autores ressaltam que o RPG educativo que foi elaborado em sua pesquisa, pode ser adaptado para interesses específicos dos docentes em relação à série que será aplicado e à realidade dos estudantes.

Demais trabalhos também exploraram o uso do RPG no ensino de ciências e verificaram a eficiência deste jogo como ferramenta no processo de ensino e aprendizagem de ciências, além das outras qualidades presentes neste jogo para a educação em geral (FERREIRA et al., 2007; OLIVEIRA, R.; PIERSON; ZUIN, 2009; RANDI; CARVALHO, 2013; REZENDE; COELHO, 2009).

Quanto às contribuições do RPG para a educação, Silva (2009) ressalta o que pode ser, segundo o autor, a maior contribuição que este jogo oferece no cenário educacional:

\footnotetext{
${ }^{13}$ ZACCAGNINO, V. Il gioco di ruolo come setting esperenziale. Vita, gioco, educazione: una transitività metaforica. Basilicata Italia, Tese. Università degli Studidella Basilicata Emilio Lastrucci, 2006.
} 
Talvez a maior contribuição que o jogo de papéis traz para a educação, além da possibilidade de se discutir assuntos do cotidiano de forma que a discussão faça algum sentido, é a possibilidade do crescimento individual - experimentação de novos papéis, novas vivências, e do crescimento social - relacionamento cooperativo com diferentes pessoas. A possibilidade de participar de forma ativa de experiências, compartilhar idéias e chegar a conclusões individuais e em grupo, gerando a aprendizagem é possivelmente a maior contribuição do jogo de papéis para a educação (SILVA, 2009, p. 80).

O autor Silva (2009) também destaca que como qualquer tecnologia educacional, o sucesso do uso do RPG para melhorar o processo de ensino e aprendizagem, depende de como será utilizado. Pois como enfatiza o autor, nenhuma tecnologia educacional por si só garante um melhor aprendizado.

Silva (2009) ainda complementa que o jogo de papeis pode ter como diferencial das outras tecnologias educacionais o fato de motivar para a busca de novos conhecimentos, desenvolver valores sociais e ser uma tecnologia independente de eletricidade. Sendo o RPG, segundo o autor, uma tecnologia dependente de energia e vontade humana, dependente de colaboração. Ressaltando que ao se introduzir novas abordagens e novas tecnologias no ensino, é essencial manter o que é básico e indispensável no processo anterior, escrevendo sobre a base e não eliminando a base, novas tecnologias devem ser aderidas às já existentes, serem somadas no processo todo da educação, para serem utilizadas no que apresentam de diferentes das preexistentes.

Com base em todo o levantamento bibliográfico realizado, a presente pesquisa busca promover uma reflexão a respeito das possibilidades educacionais contidas no uso do RPG no ambiente escolar, com a participação voluntária dos alunos intermediada pelo professor o qual é o mestre da aventura, em uma atividade que aborda conteúdos disciplinares do currículo, mas acontece fora do horário das aulas. 


\section{METODOLOGIA}

Neste capítulo é descrito o processo metodológico adotado neste estudo. Inicia-se pela descrição dos passos que antecederam a pesquisa, segue-se pela execução desta e finaliza-se com procedimentos de análise dos dados coletados neste estudo.

\subsection{PROCEDIMENTOS PRELIMINARES À PESQUISA}

A pesquisa foi realizada em uma escola particular, com alunos do oitavo ano do Ensino Fundamental. Neste colégio as aulas do Ensino Fundamental II ocorrem no período da manhã. Como a proposta da pesquisa é o uso do role-playing game na escola como uma atividade voluntária e complementar, os alunos foram convidados a participarem desta pesquisa, ou seja, das sessões de RPG, no período da tarde.

A sala do oitavo ano apresentava 21 alunos. À princípio, 18 alunos quiseram participar das seções de RPG. Foi entregue para esses 18 alunos, e também para os outros 3 que não quiseram participar, um convite com uma breve explicação sobre o que é um roleplaying game e uma folha para que os pais dos alunos que fossem participar assinassem autorizando a participação dos seus filhos na atividade.

O objetivo da entrega deste texto com uma breve explicação sobre RPG, foi o de contextualizar os pais dos alunos, e também os próprios estudantes, sobre o jogo que iriam jogar se participassem da pesquisa.

Também foi feita uma explicação oral em sala de aula para os discentes, com o mesmo objetivo de contextualização. Foi enfatizado para eles, tanto na apresentação oral, quanto no texto, que o RPG iria abordar conteúdos de ciências em meio ao jogo, e que o mestre do jogo (foi explicado para eles, no texto e na apresentação, o conceito de mestre no role-playing game) seria o professor de ciências (autor desta pesquisa).

Também foi avisado, tanto na apresentação quanto no texto, que os alunos seriam divididos em turmas de 5 a 8 alunos por turma. Cada turma iria jogar o RPG dois dias por semana, durante 1 hora e 30 minutos por dia. Ao todo seria um período de aproximadamente dois meses nos quais seriam realizadas as seções de RPG todas as semanas. 
$\mathrm{Na}$ data marcada para recolher, na sala de aula, as autorizações assinadas pelos pais, confirmando a participação do aluno na pesquisa que iria ocorrer, confirmou-se que 15 alunos iriam participar da pesquisa. Havia mais 3 alunos que queriam participar mas justificaram que devido a compromissos, dos alunos e/ou familiares, não poderiam estar presentes nos dias e horários estabelecidos para a realização das sessões de RPG.

E então assim deu-se inicio a aplicação da pesquisa, sendo os sujeitos da pesquisa estes 15 alunos do oitavo ano do ensino fundamental, e por dois meses o autor desta pesquisa e alunos, juntos, jogaram o RPG, envolvendo conteúdos de ciências.

Assim como as personagens das histórias de aventura, quando embarcam em uma jornada, estes 15 alunos e o professor embarcaram na expedição de realizar e fazer parte desta pesquisa.

\subsection{A PESQUISA}

O presente estudo é uma pesquisa qualitativa exploratória, com base nas metodologias de pesquisa descritas no livro de Moreira e Caleffe (2008). Para investigar as possibilidades proporcionadas pelo uso do RPG na escola, com ênfase na observação do potencial do jogo de RPG como uma estratégia para um ensino complementar em ciências, com a participação voluntária dos alunos, fora do horário das aulas curriculares.

\subsubsection{Os sujeitos da pesquisa}

A pesquisa foi realizada com 15 alunos do oitavo ano do Ensino Fundamental. Eles foram divididos em dois grupos:

Um grupo contendo 8 alunos, sendo 4 meninas e 4 meninos. Para jogar o RPG, com o professor de ciências, nas segundas e quintas feiras, das $13 \mathrm{~h}$ às $14 \mathrm{~h} 30 \mathrm{~min}$.

Outro grupo contendo 7 alunos, sendo 2 meninas e 5 meninos. Para jogar RPG, com o professor de ciências, nas quartas feiras, das $13 \mathrm{~h}$ às $14 \mathrm{~h} 30 \mathrm{~min}$ e nas sextas feiras, das $16 \mathrm{~h} 30 \mathrm{~min}$ às $18 \mathrm{~h}$. 
Os dias e horários foram estabelecidos de acordo com a disponibilidade de salas no colégio, para a realização da atividade, bem como pela disponibilidade do professor de ciências.

Os 15 alunos foram divididos em duas turmas devido a proposta da pesquisa, que é jogar RPG com os alunos, o mais próximo possível da maneira que o RPG é jogado como forma de lazer, e geralmente esse jogo é realizado com grupos de no máximo 10 pessoas, sendo mais comum grupo de 5 pessoas. Embora, como se pode observar no levantamento bibliográfico, seja possível se adaptar o RPG para aplicação na sala de aula, com números em torno de 20 a 30 alunos ou mais. Esta não foi a proposta nesta pesquisa.

A distribuição dos alunos dentro de cada turma foi estabelecida meramente pela disponibilidade dos alunos para os horários oferecidos para jogar o jogo.

Sendo assim as duas turmas foram submetidas sob as mesmas condições, os mesmos espaços para a realização do jogo, o mesmo jogo, o mesmo cenário de campanha, as mesmas regras, os mesmos conteúdos de ciências abordados, o mesmo tempo de jogo, a mesma condição de participação voluntária, o mesmo professor como sendo o mestre no RPG, portanto, não há nenhuma diferença entre as duas turmas quanto aos processos metodológicos aplicados.

Foi escolhido desenvolver esta pesquisa com alunos do oitavo ano devido dois motivos:

- A faixa etária na qual estes alunos se encontram, geralmente de 12, 13 ou 14 anos, sendo permitida a temática do jogo, cenário, que foi escolhida, na história fictícia criada pelo professor para a campanha no jogo. Inspirada em filmes que são indicados para esta faixa etária, tendo como principais inspirações $\operatorname{Star}$ Wars ${ }^{14} \mathrm{e}$ Star $\operatorname{Trek}^{15}$. Aproveitando o atual retorno destas franquias ao cinema, e a popularidade que elas têm em meio aos jovens.

- O ano escolar no qual se encontram, pois foi escolhido avaliar a eficiência do RPG no ensino de ciências, por meio de abordar no jogo, um assunto que estes alunos não viram em sala de aula, portanto foi escolhido um tema do nono ano: os conceitos fundamentais de ácido, base e escala de pH. Caso contrário, não seria

\footnotetext{
${ }^{14}$ Star Wars é uma franquia de aventura/ficção científica, criada pelo cineasta George Lucas.

${ }^{15}$ Star Trek é uma franquia de ficção científica baseada na série de televisão criada por Gene Roddenberry.
} 
possível mensurar se o aprendizado ocorrido foi por meio do jogo de RPG como estratégia educacional, ou foi por meio das aulas normais do oitavo ano.

4.2.2 Os temas de ciências abordados durante as partidas

Como mencionado no tópico anterior, o principal tema de ciências abordado durante as partidas de RPG foram os conceitos fundamentais a respeito de ácido, base e escala de $\mathrm{pH}$. Este tema foi escolhido para ser avaliado, quanto a sua aprendizagem, ao final da pesquisa, na forma de um teste múltipla escolha, e também pela análise de questionários. (este teste e os questionários serão tratados em outro tópico).

No entanto foram abordados outros temas de ciências durante o jogo, os quais não tiveram a sua aprendizagem avaliada, no entanto foi possível analisar a impressão dos alunos a respeito do contato com esses temas, por meio dos questionários.

Os temas de ciências abordados durante o jogo foram principalmente os conceitos fundamentais de:

- Ácido, Base e Escala de pH.

- Densidade.

- As três Leis de Newton.

- Zoologia: Artrópodes: Insetos.

Optou-se por avaliar somente a aprendizagem a respeito de ácido, base e escala de $\mathrm{pH}$, pois foi esse tema que teve a aplicabilidade do seu conhecimento proporcionada diretamente pela a aventura de RPG, elaborada para esta pesquisa. 
4.2.3 As regras do RPG jogado durante a pesquisa

Com o objetivo de ter o foco na aprendizagem dos conceitos fundamentais de ácido, base e pH, e também em proporcionar possibilidades de cooperação na resolução de problemas e envolvimento dos alunos com a atividade, optou-se por não adotar regras de sistemas de RPG preexistentes no mercado, ao invés disso o autor da pesquisa elaborou um sistema de regras muito simples, com o objetivo de proporcionar o fator desafio para o jogo, bem como a aleatoriedade, por meio do lance de dados e a estratégia em equipe, por meio de diferentes classes, habilidades e equipamentos que os alunos puderam escolher para as suas personagens, as quais foram criadas pelos alunos, que também exercitaram a escrita ao escreverem as histórias de seus personagens e apresenta-las para o professor e para o grupo de jogadores.

As regras criadas para esse RPG, embora muito simples, puderam proporcionar aos alunos a experiência de jogar RPG, e de se manterem entretidos com o jogo. A simplicidade das regras não interferiu na dinâmica e no propósito do jogo de RPG, pois o verdadeiro fundamento do role-playing game está na interpretação dos personagens e na narrativa. A criação destas regras teve sua inspiração em um dos sistemas de RPG mais divulgados no mundo, o Dangeons and Dragons ${ }^{16}$, também conhecido como $D \& D$. Sistema de RPG disponível no mercado brasileiro, na forma de livros de regras e de cenários.

Portanto foram utilizados no jogo os mesmos dados utilizados no $D \& D$. Os quais são dados de diversas faces e também o tradicional dado de 6 faces. Poderia ter sido usado apenas os dados de 6 faces, mas foi percebido nas preliminares da pesquisa que os dados diferentes e coloridos despertam a atenção dos alunos, aumentando o envolvimento dos alunos com a atividade. Na figura 1 observam-se os dados utilizados no jogo:

\footnotetext{
${ }^{16}$ COOK, M.; Tweet, J.; Willians, S. Dungeons \& Dragons: Livro do Jogador. São Paulo: Devir Livraria, 2001. Tradução: Castro, F. C.
} 
Figura 1 - Dados de RPG utilizados: da esquerda para a direita apresenta-se respectivamente o dado de 20 faces, o de 12 faces, o de 10 faces, o de 8 faces, o de 6 faces e o de 4 faces.

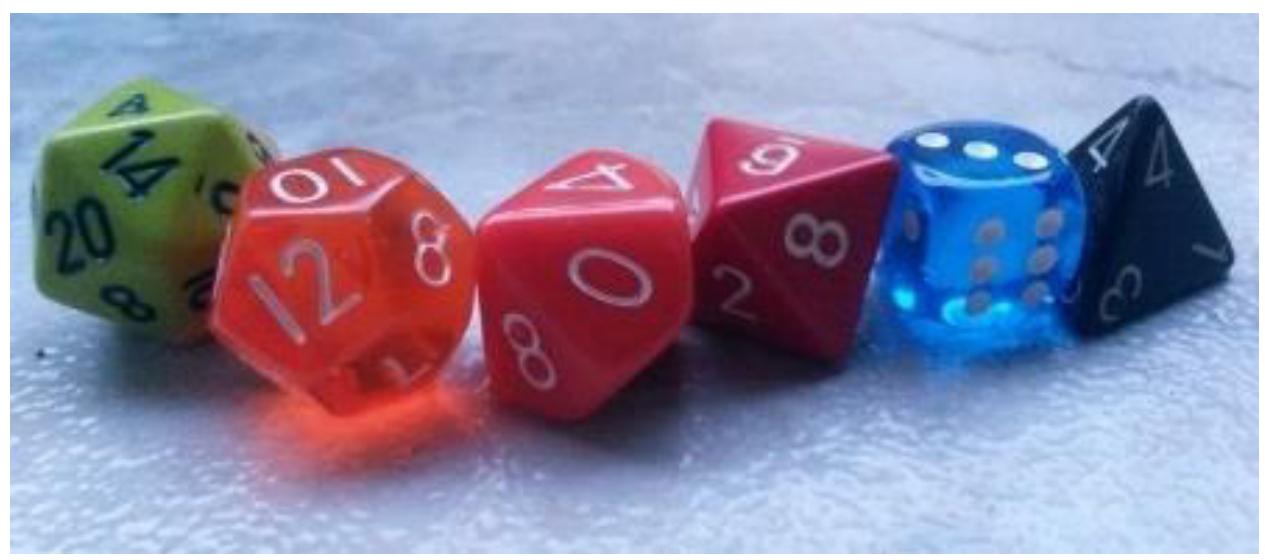

Fonte: Arquivo pessoal.

No jogo também foram utilizadas miniaturas, pertencentes ao autor, as quais não são necessárias para se jogar RPG, mas o uso delas proporcionou maior ludicidade para os alunos.

Na figura 2 é possível visualizar os alunos jogando e utilizando as miniaturas e os dados no jogo.

Figura 2 - Alunos em uma das sessões de RPG ocorridas durante a pesquisa.

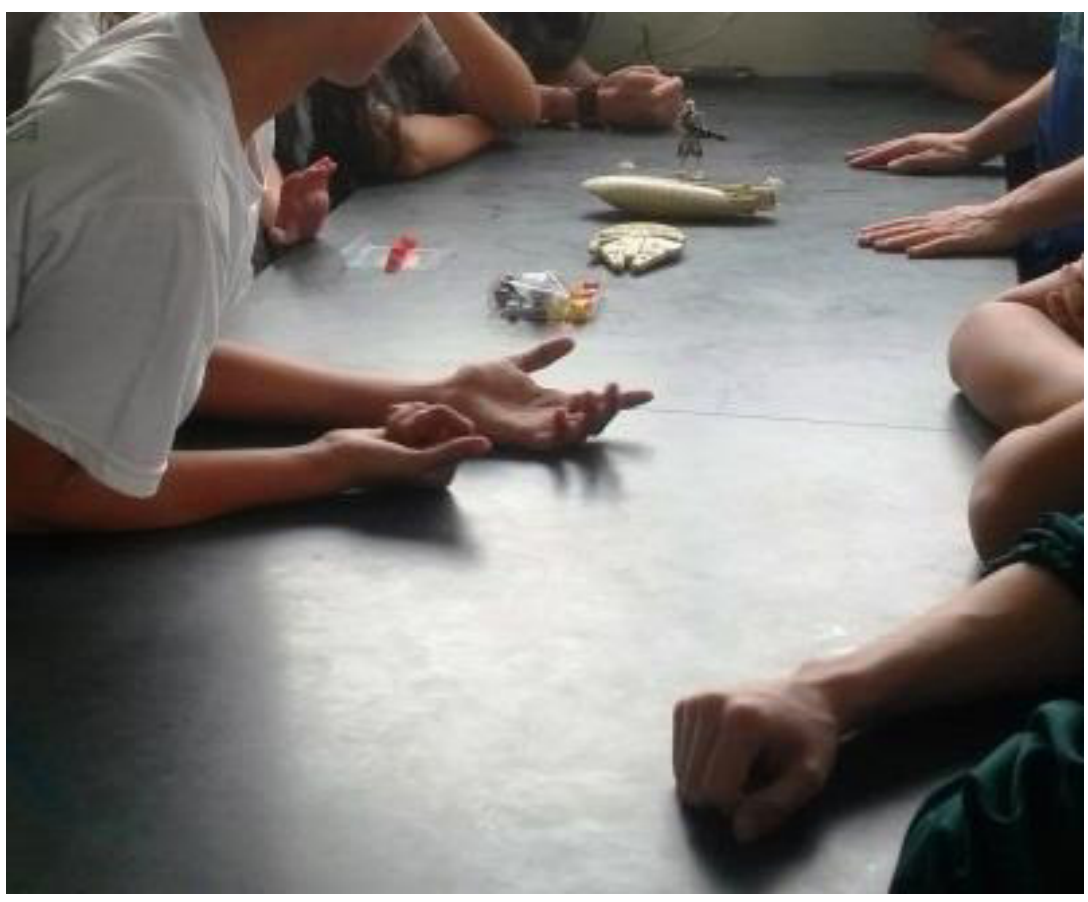

Fonte: Arquivo pessoal. 
Um diferencial acrescentado pelo autor neste RPG foi que, a turma de alunos, tinha o direito de realizar três vezes por sessão, a substituição de uma falha no lance de dados, pela resolução de um exercício de ciências sobre os conceitos fundamentais de ácido, base e escala de $\mathrm{pH}$. Uma opção ao jogador de substituir um resultado ruim nos dados de sua jogada, pela oportunidade de responder um exercício, substituindo a falha no dado por um sucesso, no caso de acertar o exercício, e mantendo a falha no caso de errar. Com um limite do uso desse recurso no jogo, sendo limitado à três vezes por sessão de RPG, para todo o grupo de jogadores, e não por jogador.

O objetivo dessa estratégia foi fazer com que os alunos permanecessem estudando e treinando os conceitos de ácido, base e escala de $\mathrm{pH}$, mesmo nos momentos em que estes conceitos não estavam em evidência na narrativa da história do jogo. Geralmente coincidiam de serem os momentos de maior número de lances de dados, como no caso dos combates dos heróis (personagens dos alunos) contra os vilões (NPC).

Foi pedido aos alunos que escrevessem semanalmente um resumo das aventuras jogadas na semana, um diário de aventuras, como foi chamado, e desta forma ao longo da aplicação da pesquisa os alunos escreveram um resumo de toda a campanha jogada. A leitura destes diários de aventuras, pelo autor, fez parte dos dados observacionais que serão tratados no próximo capítulo.

\subsubsection{Instrumentos de coleta de dados}

Foi realizada a observação durante as seções de RPG, onde após o final da seção o autor anotava as observações principais em um diário da pesquisa. Também foram anotadas observações pertinentes ao trabalho realizadas no dia a dia, como por exemplo, quando os alunos procuravam o autor no intervalo das aulas para conversarem sobre o RPG. Estas anotações, em conjunto com os diários da aventura escritos pelos alunos, constituíram a coleta de dados observacionais. E a leitura de ambos possibilitou o registro dos principais dados observacionais nesta pesquisa.

As seções de RPG duraram aproximadamente dois meses. Após encerrarem, a história da campanha ter sido concluída, a atividade foi encerrada, na forma de uma reunião com os alunos onde o professor conversou com os alunos perguntando para eles o que eles sentiram jogando RPG e como foi para eles toda a experiência, quais foram os 
aprendizados que eles levaram consigo desta experiência. Foi uma conversa informal e descontraída. Na qual foram anotados dados observacionais a respeito.

Depois da data desta conversa, durante dois meses não foi realizada mais nenhuma atividade relacionada ao RPG. Até que então, dois meses após o final das atividades com RPG, foram aplicados, com os 15 alunos que participaram da pesquisa, os questionários e o teste sobre os conceitos fundamentais de ácido, base e escala de $\mathrm{pH}$.

O motivo de ter-se optado por esperar dois meses para aplicação dos questionários foi para que se espere passar o que se pode chamar de efeito da empolgação. O objetivo era coletar as reais opiniões e impressões dos alunos. Para tanto os questionários foram anônimos, para que pudessem ser sinceros em suas opiniões sem se sentirem constrangidos e, pelo mesmo motivo, se esperou passar dois meses, para que a empolgação dos alunos com o jogo diminuísse, e fossem, portanto, obtidas as verdadeiras opiniões e impressões que tiveram a respeito da experiência de jogar RPG na escola, bem como de ter contato com conteúdos de ciências por meio do RPG.

O motivo de se esperar dois meses para se aplicar o teste foi para mensurar a retenção do aprendizado pelos alunos, avaliando assim a aprendizagem deles a respeito do tema selecionado, por meio do RPG como estratégia educacional.

Foram feitos: Um questionário múltipla escolha com quatro perguntas, as quais estarão transcritas no próximo capítulo, Três perguntas dissertativas, sendo uma delas bem aberta, para poder colher as mais diversas opiniões, expressões e sensações dos alunos. As quais também estarão transcritas no capítulo seguinte. E um teste múltipla escolha (Anexo 1), a respeito dos conceitos fundamentais de ácido, base e escala de $\mathrm{pH}$, o qual o resultado será discutido no capítulo seguinte. Embora questionários, sejam instrumentos comuns de pesquisas quantitativas, de acordo com Silva (2009, p. 84), que enfatiza, “[...] é o uso que se faz do instrumento (no caso o questionário) que aponta para o tipo de pesquisa.”.

Para a análise das respostas às perguntas dissertativas, optou-se por uma análise qualitativa, definida por Moreira e Caleffe (2008). De acordo com esses autores, essa análise é de certo modo problemática, devido a depender da interpretação do observador, pois um mesmo fato pode ser descrito de formas diferentes dependendo da interpretação de cada observador. Para contornar a característica dessa análise, além da interpretação serão apresentados trechos das respostas dos alunos correspondentes ao grupo analisado.

Como normalmente esse tipo de análise é feita com base em transcrição de conversações, ou a respostas a questionários, que é o caso dessa pesquisa, é difícil um 
estudo estatístico. Por esse motivo, Moreira e Caleffe (2008), definiram esse tipo de análise como uma pesquisa qualitativa.

Nesse trabalho, para analisar as respostas dos alunos às perguntas dissertativas procedeu-se primeiramente, a leitura de todas as respostas, em seguida, procurou-se agrupá-las em grupos e subgrupos que, de acordo com a interpretação, representavam respostas parecidas. Os diversos grupos foram organizados e apresentados em tabelas, com trechos, ou com as respostas completas dos alunos para que a análise dos resultados não fique totalmente dependente da interpretação do autor. 


\section{RESULTADOS E DISCUSSÕES}

Neste capítulo são discutidos os resultados obtidos por meio do teste, buscando verificar a aprendizagem dos alunos. Bem como são analisados e discutidos os resultados obtidos por meio dos dados observacionais, para isso, é descrita resumidamente as aventuras, ou seja, a história do jogo, em paralelo com o levantamento das observações realizadas pelo autor durante as sessões de RPG e também no dia a dia escolar e na leitura dos diários de aventura dos alunos. É feita também uma análise e discussão das respostas dos alunos ao questionário múltipla escolha e às perguntas dissertativas.

A análise dos resultados possibilita uma avaliação sobre as possibilidades educacionais da implementação do role-play game no ambiente escolar como uma atividade pedagógica complementar e voluntária.

\subsection{APRENDIZAGEM DOS CONCEITOS FUNDAMENTAIS DE ÁCIDO, BASE E ESCALA DE POTENCIAL HIDROGÊNICO, POR MEIO DO USO DO RPG COMO ESTRATÉGIA EDUCACIONAL:}

Neste tópico discutimos os resultados que os alunos obtiveram no teste a respeito dos conceitos básicos de ácido, base e escala de $\mathrm{pH}$, interpretando estes resultados em conjunto com as observações realizadas pelo professor durante as partidas e no dia a dia escolar, o que compreende parte dos dados observacionais coletados nesta pesquisa.

O teste (Anexo A) contou com 5 questões de múltipla escolha sobre os conceitos de ácido, base e escala de $\mathrm{pH}$, sendo cinco alternativas em cada questão, contendo apenas uma alternativa correta. Todos os 15 alunos que participaram da pesquisa obtiveram $100 \%$ de acerto neste teste, mesmo tendo sido aplicado dois meses após o término da experiência.

Este resultado aponta para uma elevada eficiência do role-playing game como uma estratégia para o ensino de ciências, indicando grande potencial do uso deste jogo no processo de ensino e aprendizagem. Como foi também observado por Ferreira et al. (2007), Oliveira, R., Pierson e Zuin (2009), Randi e Carvalho (2013) e Rezende e Coelho (2009). 
Como na presente pesquisa o RPG foi utilizado como um jogo em seu pleno significado, de acordo com as características fundamentais do jogo definidas por Huizinga (2008), pode-se considerar que consistiu também em um meio de educação informal, como descrito por Brougère (2002). Mesmo o jogo tendo sido aplicado dentro da escola, e mesmo neste caso tendo a intenção de ensinar, é possível que nem sempre a intensão dos alunos foi de aprender. Pois pode-se pensar que, uma vez que a atividade não valia nota para os alunos, ocorria fora do horário das aulas oficiais e com a participação voluntária deles, eles poderiam em muitos momentos estar participando apenas pela diversão, pelo fato de estar com os amigos em um contexto de lazer lúdico. E dentro deste contexto eles podem ter construídos alguns conhecimentos sobre ciências mesmo que sem a intenção de fazê-lo, ou seja, podem ter aprendido pela educação informal.

Porém houveram também momentos observados, e também expressados pelos alunos em suas respostas às perguntas dissertativas, que serão abordados em um tópico seguinte, em que os alunos estavam motivados a estudar e a entender conteúdos de ciência. Portanto não se pode afirmar que o RPG, no contexto desta pesquisa, foi o tempo todo um meio de aprendizagem informal. Mas pode-se supor que o jogo variou entre as duas posições, estando horas na posição de uma aprendizagem com intenção de aprender, e horas na posição de aprendizagem informal. Mas se manteve o tempo todo dentro do conceito pleno de jogo estabelecido por Huizinga (2008).

No trabalho de Dias, Novaes e Rosalen (2015), sobre a aplicação de um jogo eletrônico para o ensino de ciências, foi observado que o uso do jogo melhorou a formação, evocação e manutenção das memórias relacionadas aos conteúdos da disciplina, pelo fato das memórias estarem sendo moduladas pelo ânimo e emoções dos alunos enquanto jogavam, e também pelas associações prazerosas que faziam à atividade com o jogo eletrônico. Isso pode talvez, ter sido também a causa de uma manutenção elevada da memória com relação aos conteúdos de ácido, base e escala de $\mathrm{pH}$ que ocorreu nos sujeitos da presente pesquisa.

Mas é preciso levar em consideração o que é apontado por Fairchild (2004) quanto a importância de pesquisas cada vez mais aprofundadas sobre o uso do RPG na educação. Somente com o resultado deste único teste, realizado na presente pesquisa, não podemos afirmar que foi realmente o uso do RPG que proporcionou tal resultado, mesmo os alunos não tendo aprendido esses conceitos de química nas aulas do oitavo ano, como foi mencionado na metodologia, por se tratarem de assuntos trabalhados no nono ano, motivo pelo qual tais conceitos foram escolhidos para mensurar a influência do RPG como 
estratégia didática no processo de ensino e aprendizado. Pois como alerta Fairchild (2004), os estudantes poderiam ter chego ao mesmo aprendizado de outras maneiras, não é obrigatória e indispensável a ludicidade e dinâmicas proporcionadas pelo RPG para tal construção de conhecimento.

Talvez a estratégia de utilizar exercícios de ácido, base e escala de pH, como uma segunda chance após uma falha no lance de dados no jogo, durante dois meses de jogo, pode ter proporcionado a repetição e treinamento constante em exercícios deste mesmo tema, levando talvez a uma memorização pelo treino e repetição. Mesmo o uso desta estratégia tendo sido limitada pelo mestre, à no máximo três segundas chances por partida, como explicado na metodologia, e mesmo os exercícios do teste, aplicado após dois meses do final do jogo, não terem sido os mesmos realizados durante as partidas, ainda assim eram do mesmo tema, e no mesmo nível de dificuldade. Tendo o propósito de avaliar os conceitos básicos a respeito de ácido, base e escala de $\mathrm{pH}$, tal qual foi a proposta de ensino a ser realizada por meio do role-playing game.

Portanto é recomendado um estudo mais aprofundado e específico a respeito da influência do RPG na formação, evocação e manutenção das memórias.

No entanto as observações realizadas durante as partidas registram um aumento no interesse dos alunos por realizar estes exercícios, para anular um resultado ruim no lance de dados, do momento em que começaram os combates (entre os personagens dos jogadores e os vilões na história do jogo), e portanto maior número de jogadas com dados, até o final da campanha, até a conclusão da batalha na qual os personagens participaram.

Esta observação pode indicar maior confiança dos alunos em seus conhecimentos a respeito destes conteúdos, os quais estavam sendo construídos ao longo do jogo. O que vai ao encontro do que foi observado na revisão bibliográfica, quanto ao jogo aplicado à educação promover maior segurança ao aluno com relação aos seus conhecimentos e à expressá-los, e também aumentar o interesse do aluno em participar das atividades (BARBOSA; CARVALHO, 2008).

Foi observado também que no momento da realização do teste, os alunos estavam empolgados e confiantes, nenhum aluno apresentou dúvidas durante a realização deste teste. E é comum, durante a exerção da atividade pedagógica, notar-se alunos que apresentam dúvidas em momentos de avaliações ou atividades, que são em sua maioria manifestação de insegurança e desconforto emocional, geralmente nomeado pelos alunos de "nervoso", "medo", "nervosismo". Ou seja, o aluno já aprendeu aquele conhecimento, 
mas não apresenta segurança em expressá-lo, seja verbalmente, ou na forma escrita em uma prova.

Durante o jogo de RPG foi observado esta mesma insegurança nos alunos no inicio, quando começaram a optar por responder os exercícios, de forma verbal ou escrita, durante alguns momentos do jogo. Mas à medida que os dias foram passando e as sessões iam acontecendo, essa insegurança quanto a se expressar, ou realizar um exercício de ciências durante o jogo, foi diminuindo e até em alguns casos desaparecendo, não sendo mais possível notar insegurança em alguns alunos quanto a este tema de ciências, e no lugar notando firmeza e confiança em sua própria fala.

Foi observado que, os alunos os quais já estavam mais seguros de seus conhecimentos, estavam ajudando os amigos que ainda não estavam tão seguros, buscando ensinar-lhes, e também motivar. Esta cooperação no aprendizado foi observada diversas vezes ao longo das sessões de RPG e, não somente, referente aos conteúdos de ácido, base e escala de $\mathrm{pH}$, mas também quanto a outros temas da ciência. O que indica que o RPG pode proporcionar o aprendizado por meio da zona de desenvolvimento proximal, como foi levantado na literatura (SCHMIT; MARTINS, 2011).

Mais apontamentos podem ser feitos com relação ao aprendizado de ciências por meio do uso de RPG, como uma atividade voluntária e complementar, por meio da análise das respostas dos alunos às questões dissertativas, nos tópicos mais adiante neste texto.

\subsection{AS IMPRESSÕES DOS ALUNOS QUANTO A EXPERIÊNCIA DE JOGAR} ROLE-PLAYING GAME NO AMBIENTE ESCOLAR COM O PROFESSOR:

Neste tópico é demonstrado alguns dos principais dados observacionais coletados. Para isso optou-se por transcrever aqui um breve resumo da história fictícia a qual foi a campanha jogada neste RPG, dando maior ênfase em partes que a leitura facilita entender algumas das falas dos alunos em suas respostas às questões dissertativas, analisadas mais a frente ainda neste segmento, e principalmente nas referentes quanto ao aprendizado de ciências, analisadas no tópico seguinte. É feita a análise das respostas dos alunos ao questionário múltipla escolha e as respostas às duas perguntas dissertativas, uma referente à como foi na visão deles essa experiência de jogar RPG na escola, e outra à recomendação, ou não, por parte dos alunos, sobre o uso do RPG no ensino. 
5.2.1 O cenário e a história da campanha jogada: as principais observações relacionadas ao comportamento e ações dos alunos durante estes momentos de imaginação e ludicidade:

Segue-se um breve resumo da história que foi elaborada pelo autor, e por ele narrada, no papel do mestre de RPG durante a campanha jogada com os alunos. Em paralelo com observações realizadas durante as partidas, bem como nos intervalos entre uma partida e outra na rotina escolar e de sala de aula. E também durante a leitura dos diários de aventura, que foram escritos pelos alunos e apresentados para o autor, durante os dias da experiência com RPG.

Para facilitar a compreensão de qual segmento do texto é a narrativa da história e qual são observações realizadas pelo autor, optou-se por organizar a narrativa de maneira inspirada pela "Jornada do Herói” descrita por Joseph Campbel1 ${ }^{17}$. Escrevendo em itálico as narrativas, e as observações sendo organizadas logo após cada etapa da "Jornada do Herói" mencionada.

Primeiramente vamos descrever a ambientação, o cenário, no qual esta ficção se passou, e depois inicia-se a narrativa da aventura na qual as personagens dos jogadores fazem parte, sendo estas personagens a figura do herói na narrativa.

\section{O Cenário:}

Em um futuro distante, no ano de 2507, a humanidade participa da federação dos planetas unidos. Um governo democrático que abrange vários sistemas planetários da Via Láctea, composto por diversas civilizações, originárias de muitos mundos.

Embora nós, seres humanos do planeta Terra, já fossemos estudados por algumas das espécies alienígenas às quais integram a federação desde a nossa pré-história, foi apenas em 2017 que estas civilizações, vindas de outros planetas, decidiram se revelar para toda a sociedade humana.

\footnotetext{
${ }^{17}$ CAMPBELL, Joseph. The hero with a thousand faces. New World Library, 2008.

Desde seu lançamento em 1949, o livro "herói com as mil faces" influenciou milhões dos leitores combinando os insights da psicologia moderna com a compreensão revolucionária de Joseph Campbell da mitologia comparativa. No seu livro, Campbell descreve a jornada do herói, um motivo universal de aventura e transformação que percorre praticamente todas as tradições míticas do mundo e que tem influenciado diversos autores de obras de ficção desde então.
} 
Após esse evento que mudou a história da humanidade, o ano de 2017 passou a ser conhecido, e ensinado nas escolas, como "O Ano do Primeiro Contato", quando os seres humanos foram convidados a fazer parte de um mundo muito maior; um mundo no qual a pergunta: "Estamos sozinhos no Universo?”, foi indubitavelmente respondida.

Após o primeiro contato muita tecnologia e conhecimento passaram a ser compartilhados entre estas civilizações espaciais e os seres humanos. E então, depois de algumas décadas, a humanidade se tornou a mais nova integrante do conselho da federação dos planetas unidos. E agora em 2507 (ano terrestre) a humanidade participa de diversas atividades, integrada ao mundo mais que globalizado, um mundo onde toda a galáxia se comunica, interage, compartilha culturas, tecnologias e conhecimento.

Uma sociedade onde todo ser humano já está habituado a trabalhar lado a lado, ou ser amigo de escola, ou vizinho, de seres alienígenas dos mais diversos planetas. Onde algumas pessoas nasceram e passam quase a sua vida toda dentro de espaçonaves, navegando pela galáxia. Uma sociedade muito avançada, e unida, mas que ainda apresenta muitos problemas a serem resolvidos.

\section{Dados observacionais referentes à "O Cenário":}

Ao narrar esse cenário para os alunos, quando nos reunimos na primeira sessão de RPG para a construção dos personagens, a aceitação da ideia pelos alunos foi imediata, eles se mostraram muito entusiasmados e interessados em fazer parte desse processo criativo, de poderem somar a esse cenário seus personagens e suas histórias de ficção.

Os estudantes elaboraram personagens bastante diversificados, havia personagens bélicos, como guerreiros, militares, pilotos de caças de combate, mas também foram criados personagens não belicosos, como médicos, pesquisadores e engenheiros.

Em todo o momento era aproveitado para compartilhar com os alunos conteúdos de ciências. Um bom exemplo foi um aluno que criou um personagem alienígena, ele criou a espécie, e descreveu as condições ambientais do planeta de origem onde esta espécie evoluiu. Nesse momento foi possível dialogar com os alunos um pouco sobre pressões evolutivas e adaptações dos seres vivos.

Outro bom exemplo foi ao descrever as tecnologias fictícias deste cenário para os alunos, pois era possível traçar paralelos com as tecnologias reais existentes hoje em dia e a tecnologia presente na fantasia, sendo possível dialogar sobre algumas teorias, e pesquisas em diferentes áreas. 
Os alunos narravam verbalmente suas ideias de personagens e histórias, e faziam anotações, começando a escrever os textos sobre as características de seus personagens e suas histórias de origem. Alguns textos apresentavam maior nível de complexidade do que outros, mas, foi observado que mesmo alguns alunos que em provas dissertativas apresentavam dificuldade em dissertar suas respostas, nesta atividade se mostravam motivados e interessados em escrever.

O processo criativo em conjunto com os alunos, lembrava ao de uma oficina de texto, uma atividade sobre narrativa, fomentando a criatividade dos estudantes e motivando-os à escrita. Sendo esta uma característica do RPG, já observada e explorada na literatura por Andrade e Carneiro (2007), Chung (2013), Dayson et al. (2016), Rodrigues (2004), Saldanha e Batista (2009) e Silva (2009).

$\mathrm{O}$ role-playing game pode ser um dos caminhos pelos quais a educação pode fomentar a criatividade e a engenhosidade, o que deve ser uma das prioridades dos sistemas educacionais, como afirma Hargreaves (2004).

\section{O Chamado para a Aventura:}

A tripulação [personagens dos jogadores] de uma espaçonave de pesquisa, pertencente à frota da federação, foi convocada para resgatar sobreviventes da queda de uma nave cargueira em um planeta de ambiente hostil.

Esta nave cargueira carregava cristais que são usados para energizar usinas fornecedoras de energia elétrica em diversos planetas. Estes mesmos cristais nas mãos erradas, podem ser utilizados para a produção de perigosas armas de destruição em massa.

A missão é encontrar o local de queda da nave cargueira, resgatar a tripulação $e$ os cristais. Antes que piratas espaciais, que atacaram a nave cargueira, provocando a sua queda, a encontrem primeiro e se apoderem dos cristais.

\section{Dados observacionais referentes à "O Chamado para a Aventura":}

Os alunos se encontravam em estado de elevado entusiasmo, o que pode ser observado posteriormente na análise de suas respostas as perguntas dissertativas. Eles pareciam demonstrar uma alegria por fazerem parte deste grupo, por serem em suas imaginações a tripulação desta nave em missão de resgate. E por serem em sua realidade 
parte de um grupo de amigos, em uma atividade conjunta e diferente, na qual eles interagem pessoalmente e não por meio de dispositivos eletrônicos.

O RPG pode ser uma importante estratégia na promoção do contato social, das interações pessoais presenciais e não à distância, um resgate às horas de diálogo presencial, sem os olhares se dirigirem às telas de celulares em meio à conversa.

Durante as partidas de RPG, os alunos conseguiram se distanciar mais de seus celulares, não sentiram falta de permanecerem verificando as redes sociais constantemente, algumas vezes inclusive, partia deles mesmo, agruparem todos os celulares em um canto em uma mesa mais afastada, ou até mesmo no chão, longe dos jogadores.

O RPG como tecnologia educacional possibilitadora da aprendizagem social foi estudado por Silva (2009), que também afirma sobre a importância para o jovem de pertencer a um grupo. Saldanha e Batista (2009) ressaltam que o principal fator motivacional dos jogadores de RPG é a amizade, a vontade de estar com os companheiros de jogo.

Tais características do role-playing game podem ser muito importantes não somente para as escolas atuais, mas para a sociedade da informação e do conhecimento como um todo. Resgatando e desenvolvendo a capacidade de se relacionar com as pessoas, educando para além da sociedade da informação e do conhecimento, constituindo uma educação que promova a transferência para a vida social de novas atitudes e valores nas relações humanas. Contribuindo com o modelo de educação defendido por Dowbor (2001), Hargreaves (2004), Moraes (2016) e Silva (2009).

\section{O Encontro com o Mentor e a Travessia do Limiar:}

A tripulação quando chega ao local de onde partiu o pedido de socorro, não encontra os sobreviventes, encontra apenas a nave cargueira arrebentada contra o solo do planeta, na tentativa de um pouso de emergência.

Os heróis percebem que algo fez os sobreviventes fugirem do local. Eis que ao verificarem atentamente o interior da nave acidentada eles encontram um sobrevivente inconsciente, que ao despertar lhes conta o que aconteceu e orienta o grupo de heróis sobre toda a situação.

A partir deste momento em diante a tripulação, formada agora pelos heróis e este sobrevivente, se depara com diversas ameaças em um planeta habitado por bandos de incontáveis insetos gigantes e predadores, rios extremamente ácidos e atmosfera tóxica. Juntos elaboram estratégias para superarem as dificuldades, encontrarem os 
sobreviventes e assegurar a preciosa, e ao mesmo tempo perigosa, carga encontrada nos destroços da nave acidentada: os cristais de energia.

Dados observacionais referentes à "O Encontro com o Mentor e a Travessia do Limiar":

Foi observado cada vez mais cooperação entre os alunos, a cada dificuldade que aparecia para seus personagens na trama do jogo, mais eles elaboravam estratégias em conjunto e buscavam contribuir com a equipe.

Foram muitas vezes em que um jogador podia escolher entre uma ação que beneficiaria muito o personagem dele, mas não beneficiaria em nada o grupo, ou uma ação que beneficiaria pouco o personagem dele, mas também beneficiaria o grupo, e os jogadores (os alunos) na grande maioria das vezes escolhiam a segunda opção, pensando no bem da equipe, priorizando a cooperação.

Algumas vezes inclusive, foram observadas aqui, e também em momentos mais a frente na campanha, os alunos escolherem para os seus personagens ações que prejudicariam o seu personagem, algumas vezes até colocando a vida do personagem em risco, mas com o propósito de beneficiar muito a equipe, ou de salvar a vida de algum outro personagem, ou que seriam de grande importância para o grupo de heróis cumprirem a missão.

A característica do RPG de ser um jogo que motiva a cooperação é levantada diversas vezes na literatura em pesquisas sobre RPG, ou sobre o uso deste jogo na educação (AMARAL; BASTOS, 2011; BOLZAN, 2003; CAVALCANTI; SOARES, 2009; SILVA, 2009).

A imersão dos alunos no jogo foi profunda, eles vibravam a cada vitória de seus personagens, eles se colocavam no papel dos personagens, se imaginavam na situação, assumiam diferentes papeis e responsabilidades. Eles estavam imersos na fantasia, estavam exercitando a imaginação em um contexto lúdico, o que é apontado como uma ação saudável por Jones (2004), Rodrigues (2004), Silva (2009), Bolzan (2003),

Foi observado que alguns alunos que a principio se expressavam menos nas aventuras, agora começavam a se expressarem com maior segurança. A interação entre os alunos se apresentava maior, não somente durante o jogo, como também durante os intervalos das aulas no período da manhã. Alguns alunos que antes não falavam tanto um com o outro, passaram a se falar mais e a participar dos mesmos grupos durante os intervalos, o que pode ser evidenciado pelas falas de alguns alunos em suas respostas às 
questões dissertativas, transcritas nas Tabelas 5 e 6 . Nas quais os alunos dizem que se aproximaram mais e passaram a conversar com colegas que antes não conversavam tanto. Apontando para a importância do RPG para promover a socialização e o diálogo (SILVA, 2009), demonstrando que o RPG pode ser utilizado para levar a um ensino que, como afirma (CORTELAZZO, 2000), promova colaboração entre os alunos, estimule o trabalho em equipe e proporcione um espaço para que os estudantes ensinem uns aos outros aquilo que dominam melhor.

Durante os intervalos os alunos vinham até o professor para conversarem sobre o jogo, sobre seus personagens, sobre a história da campanha que estava acontecendo. Alguns alunos apresentavam desenhos de seus personagens, bem como de outros elementos da história do jogo, como as naves, androides, armas, equipamentos. Alguns alunos escreviam textos sobre seus personagens, aprimorando as histórias de origem do personagem, ou melhorando os seus resumos em seus diários da aventura. Silva (2009) também percebeu este comportamento nos alunos em sua pesquisa sobre o uso do RPG como tecnologia educacional.

\section{O Ventre da Baleia (Testes, Aliados e Inimigos):}

Os heróis, mantém os cristais de energia em segurança dentro de sua nave de pesquisa, a qual está pousada ao lado da entrada de uma caverna. Alguns heróis estão na nave monitorando os sensores, pois os piratas podem chegar a qualquer momento. Outros adentram a caverna, pois após análises e buscas eles descobriram o paradeiro dos sobreviventes.

O líder dos sobreviventes se chama John Willians, os heróis agora olham para ele e para os demais sobreviventes pensando e dialogando entre si sobre como eles irão realizar o resgate. Pois John Willians e os demais sobreviventes foram capturados por aracnídeos gigantes e estão presos ao teto da caverna em uma substância fibrosa que se assemelha à uma teia de aranha gigante. Os aracnídeos gigantes dormem ao lado deles, e os mantem ali presos e vivos para que eles sirvam de alimento para seus filhotes que em breve eclodirão dos ovos.

Como se isso já não fosse problema suficiente, embaixo da porção da caverna onde John Willians e os outros sobreviventes encontram-se pendurados, situa-se um enorme lago extremamente ácido, um ácido altamente corrosivo.

Após refletirem e elaborarem estratégias, falando baixo para não acordarem os enormes aracnídeos, os heróis chegam à um plano de ação, resolvem recolher um fluído 
de $p H$ extremamente alcalino que eles tinham encontrado em grande quantidade, muitos galões, na nave cargueira acidentada. Para então bombearem esse fluido para o interior da caverna, despejando-o sobre o lago ácido, promovendo uma reação química de neutralização, para que possam posteriormente entrar no lago e salvar John Willians $e$ sua tripulação.

Enquanto executam o plano a nave de pesquisa que está aguardando no solo, e sendo utilizada para bombear o fluído básico para dentro da caverna, por meio de equipamentos que os heróis tinham na nave, somado a equipamentos que eles encontraram na nave caída.

Neste momento sobrevoam à nave animais enormes, uma espécie de crustáceos enormes, e que flutuam, os quais apesar do exoesqueleto o qual se assemelha aos dos artrópodes, principalmente os da classe dos crustáceos, também apresentam uma silhueta do corpo que lembra vagamente uma enorme baleia azul. E se comportam como baleias, inclusive produzindo sons semelhantes.

Apesar de enormes estes animais não são agressivos, diferente da maioria dos insetos que os heróis encontraram neste planeta, os quais são predadores, e maiores que um ser humano, o que coloca os seres humanos, e qualquer espécie de mesmo tamanho, no cardápio.

Estes animais enormes que se locomovem flutuando, são apelidados pelos heróis de "baleinhas", e eles aprendem que estes animais são capazes de flutuar pois produzem quantidades enormes de gás em seu interior e armazenam esse gás em grandes cavidades, que conferem o corpo volumoso do animal. Esse gás é bem menos denso do que a combinação de gases que forma a atmosfera desse planeta, uma atmosfera densa, mais densa do que a do planeta Terra. Portanto, o corpo destes animais, quando inflados de gás, algo análogo à um peixe baiacu, se torna menos denso do que as camadas mais baixas da atmosfera, e sendo assim estas "baleinhas" conseguem flutuar, e também apresentam propulsão, liberando esse gás por orifícios que o expelem com elevada pressão, ocorrendo o princípio da ação e reação.

O biólogo do grupo de heróis ainda consegue identificar que o gás, que preenche as grandes cavidades do corpo desses animais flutuantes, é altamente inflamável.

Infelizmente não há tempo para mais pesquisa, a tripulação de heróis consegue resgatar John Willians e os demais sobreviventes, fugir dos aracnídeos gigantes, que acordaram, e sair da caverna. Mas neste momento são surpreendidos por um bando 
enorme de insetos que se aproxima, insetos carnívoros vorazes, de 5 metros de comprimento e 3 metros de altura. Se locomovendo rapidamente como quando um formigueiro é perturbado e as formigas saem em volta do formigueiro para protegê-lo.

Um combate intenso se inicia entre os heróis que buscam, junto com os sobreviventes resgatados, chegarem até a nave pousada, próxima a saída da caverna, e os insetos. Os integrantes do grupo dos heróis que haviam ficado na nave auxiliam usando os canhões da nave contra os insetos, eles gostariam de decolar e buscar os heróis mas não podem, se decolarem serão detectados nos radares dos piratas, que estão buscando na área por eles, pois já sabem que estão com os cristais.

Os heróis conseguem chegar até a nave e entrar, chegam feridos, mas chegam vivos, assim como os sobreviventes. A nave decola e quando ainda está a poucos metros acima do chão, é cercada pelas naves de combate dos piratas, que lhes ordenam que se rendam e entreguem os cristais, além dos sobreviventes, para que sejam usados de refém.

Os piratas espaciais tem superioridade numérica e em poder de fogo. Os heróis se encontram em uma situação da qual parece não haver como saírem vitoriosos. Eles começam a negociar sua rendição com os piratas, se comunicam via rádio com os vilões, buscando ganhar tempo enquanto elaboram um plano.

Após os heróis debaterem entre si, analisando as diversas propostas dos membros da equipe para um plano, eles conseguem juntos formular um plano de combate no qual podem vencer, mesmo estando em desvantagem podem ganhar usando a estratégia. Após combinarem o papel de cada um no plano, eles ligam os escudos e recarregam os canhões da nave, aumentam a potência do motor e a batalha começa.

Dados observacionais referentes à "O Ventre da Baleia (Testes, Aliados e Inimigos)":

Como é possível perceber pelo resumo da narrativa, foi nestes momentos da aventura que os alunos utilizaram os conhecimentos que aprenderam sobre ácido, base $\mathrm{e}$ escala de pH. E também foi quando aprenderam sobre densidade e as três leis de Newton, com o artifício lúdico dos animais flutuantes, apelidados pelos alunos de "Baleinhas". A aventura de RPG possibilitou aos alunos que visualizassem e executassem uma aplicação do conhecimento. Desta forma percebe-se como o RPG pode ser utilizado como ferramenta para aprendizagem ativa e significativa no ensino de ciências, assim como foi apontado por Ferreira et al. (2007), Oliveira, Pierson e Zuin (2009), Randi e Carvalho (2013) e Rezende e Coelho (2009). 
Também observou-se os alunos argumentando sobre qual seria o melhor plano para vencer os piratas espaciais, e durante essas discussões sobre os planos os alunos usaram conhecimentos científicos que haviam aprendido no jogo como argumento, bem como informações relacionadas a história e elementos do jogo.

Tais observações demonstram como o RPG é uma estratégia para produzir a construção conjunta de conhecimento, a educação social, a argumentação, a reflexão, estimulando o aluno a pensar, motivando o aluno a ter participação ativa em sua aprendizagem. Possibilidades estas proporcionadas pelo uso educacional do RPG, o que é observado em praticamente todos os estudos sobre o uso do RPG na educação levantados na revisão bibliográfica da presente pesquisa.

As observações realizadas ao longo das sessões de RPG apontam para a possibilidade de o RPG poder proporcionar um novo modelo de aprendizagem, sendo utilizado em conjunto com demais metodologias de ensino, somando ao repertório já existente de métodos de ensino e aprendizagem, para ser usado quando suas peculiaridades puderem contribuir com esse processo, dentro da proposta pedagógica do professor. O RPG pode ser utilizado na educação para a realização de um ensino mais adequado ao atual cenário educacional, um ensino como o que é descrito nos trabalhos de Cortelazo (1996, 2000), Cruz (2008), Dowbor (2001), Ferracioli (1999), Gadotti (2007), Hargreaves (2004), Moraes (2016), Neves e Damiani (2006), Pozo e Crespo (2009) e Silva (2009).

\section{A Grande Provação e A Glória:}

A batalha aérea contra os piratas é intensa, a situação se apresenta para os heróis como um cenário de vitória quase impossível. Mas nossos heróis conseguem triunfar superando todos os obstáculos por meio da estratégia conjunta e do trabalho em equipe.

E assim termina nossa história, os piratas são derrotados, seus caças de combate são abatidos um a um com as estratégias elaboradas pelos heróis. E então nossos heróis conseguem cumprir a missão, entregando os sobreviventes e os cristais em segurança de volta a base. Onde os heróis são recebidos com aplausos e medalhas.

\section{Dados observacionais referentes à "A Grande Provação e A Glória":}

As observações a respeito da elaboração de estratégias em conjunto, cooperação e construção conjunta do conhecimento já foram relatadas anteriormente, portanto cabe aqui ressaltar o quão elevado foi o nível de alegria dos alunos ao terem conseguido cumprir a 
missão da aventura, todos os alunos expressaram essa alegria durante a sessão de RPG, e também depois, ficando comentando os momentos marcantes da história. E todos eles enfatizaram em seus diários que seus personagens foram recebidos com aplausos e medalhas quando retornaram vitoriosos da missão.

Aparentemente os alunos sentem a vitória e a realização como se fossem seus personagens, pois embora o RPG seja como uma brincadeira de faz de conta, o sucesso da missão, na história do jogo, não era garantido, foram as decisões, estratégias e o trabalho em equipe dos alunos que possibilitaram o sucesso da missão. Eles realmente venceram os piratas, eles resgataram os sobreviventes e os cristais, eles cumpriram a missão. Os alunos demonstravam um sentimento de realização e expressavam intensamente a alegria que estavam sentido.

Esses dados observacionais possibilitam a reflexão de que, ainda que existam outros meios de se alcançar a aprendizagem ativa e significativa de ciências, e de fato existem, o role-playing game proporciona uma experiência singular e benéfica aos alunos, proporcionando inúmeros benefícios para o desenvolvimento dos jovens. Pode-se por meio da interpretação destas observações, concordar-se com a afirmação de Silva (2009) a respeito do que talvez seja a maior contribuição que o RPG traz para a educação, que é a possibilidade do crescimento individual, pela experimentação de novos papéis, novas vivências. E do crescimento social, pelo relacionamento cooperativo com diferentes pessoas, a possibilidade de participar de forma ativa, compartilhar ideias, argumentar e chegar a conclusões individuais e em grupo, construindo a aprendizagem.

5.2.2 Interpretação das respostas dos alunos ao questionário multipla escolha:

Neste segmento é exposto os resultados obtidos por meio do questionário de múltipla escolha e é realizado uma análise destes resultados.

Foi permitido aos alunos assinalarem várias alternativas em uma mesma questão. Cada tabela representa os resultados de uma questão, na qual o enunciado da questão é o próprio título da tabela, as repostas foram organizadas em ordem decrescente. 
Tabela 1 - Como o jogo influenciou o seu relacionamento com seus colegas de equipe?

\begin{tabular}{lc}
\hline Categoria de respostas & Respostas assinaladas por categoria \\
\hline Melhorou & 10 \\
Continuou o mesmo & 07 \\
Piorou & 0 \\
\hline
\end{tabular}

Nota-se que para uma maioria o relacionamento com os colegas de equipe melhorou, e para alguns continuou o mesmo, mas para nenhum aluno o relacionamento piorou. Ou seja, o RPG é um jogo que não promove rivalidade, pois não tem vencedores e nem perdedores, todos cooperam juntos por um objetivo em comum. Como é apontado por Rodrigues (2004), Silva (2009), Bolzan (2003), Rosa (2004, 2012) e Ferreira et al. (2007).

Tabela 2 - Por que você acha que o RPG deve ser uma atividade utilizada nas aulas, seja ela qual for?

\begin{tabular}{lc}
\hline Categoria de respostas & Respostas assinaladas por categoria \\
\hline Porque facilita o aprendizado & 15 \\
Porque é possível conversar e trocar & 14 \\
informações sempre que necessário & \\
Porque as aulas passam mais rápidas & 04 \\
Porque da pra fazer bagunça & 02 \\
Não acho que o RPG deva ser usado na & 00 \\
escola & \\
\hline
\end{tabular}

As categorias de respostas mais assinaladas foram, "Porque facilita o aprendizado" o que nos mostra que segundo os alunos o RPG possibilitou um aprendizado mais acessível, talvez de maior significado. E "Porque é possível conversar e trocar informações sempre que necessário" foi a segunda categoria mais assinalada. O que aponta para o caráter do RPG de promover a interação social. Um padrão semelhante de respostas de estudantes, à esta mesma pergunta pode ser notado no trabalho de Silva (2009). 
Tabela 3 - Como você acha que o RPG pode facilitar o processo de aprendizagem?

\begin{tabular}{lc}
\hline Categoria de respostas & Respostas assinaladas por categoria \\
\hline Dinamismo & 15 \\
Usando a imaginação & 14 \\
Colaboração & 13 \\
Resolvendo problemas e enigmas & 13 \\
Discussões & 11 \\
Motivação & 10 \\
Pesquisas & 09 \\
Ser várias pessoas/representar papéis & 06 \\
Não acho que o RPG pode facilitar o processo de aprendizagem & 00 \\
\hline
\end{tabular}

Nota-se que os alunos mais uma vez confirmam que ocorreu facilitação do aprendizado durante o RPG, uma vez que nenhum deles marcou a alternativa "Não acho que o RPG pode facilitar o processo de aprendizagem", e na Tabela 2 a categoria mais assinalada foi "Porque facilita o aprendizado". Pela Tabela 3 é possível observar que os alunos atribuem essa facilitação do aprendizado principalmente aos fatores: "Dinamismo", "Usando a imaginação", "Colaboração", "Resolvendo problemas e enigmas" sendo seguidos pelos demais fatores.

Isso evidencia que as características do jogo de RPG, pela visão dos alunos, estão de fato contribuindo com a aprendizagem. Inclusive a categoria "Resolvendo problemas e enigmas" denota a aprendizagem por meio da resolução de problemas, uma das maneiras de aprendizagem que pode ocorrer pelo RPG (SILVA, 2009; BOLZAN, 2003). Este modelo de aprendizagem tem demonstrado resultados positivos (MARIN et al., 2010; RANDI; CARVALHO, 2013; REZENDE; COELHO, 2009; VOGT, 2010).

Tabela 4 - Quais valores e habilidades você acha que o RPG pode ajudar a desenvolver?

\begin{tabular}{lc}
\hline Categoria de respostas & Respostas assinaladas por categoria \\
\hline Trabalho em equipe & 15 \\
Criatividade & 15 \\
Argumentação & 14 \\
Responsabilidade & 13 \\
Senso crítico & 08 \\
Justiça & 01 \\
Nenhum valor e nenhuma habilidade & 00 \\
\hline
\end{tabular}


Os resultados nesta tabela vão ao encontro dos dados observacionais: o RPG atua como fomentador da colaboração, criatividade e argumentação. Como ressaltado por Silva (2009) sobre o potencial do RPG para a educação social. É uma estratégia que pode ser usada para motivar e desenvolver a criatividade, como demonstraram Chung (2013), Dayson et al. (2016) e Karwowski e Soszynski (2008).

5.2.3 Interpretação das respostas dos alunos às perguntas dissertativas:

Seguem neste seguimento os principais trechos das respostas dos alunos, organizados nas tabelas abaixo:

Tabela 5 - Respostas referentes à pergunta dissertativa: "Escreva um texto, de no mínimo 10 linhas e no máximo 30 linhas, descrevendo como foi para você vivenciar essa experiência de jogar RPG na escola."

\section{Subcategoria $\quad$ Exemplos de respostas}

Experiência de jogar

RPG, sensações ao jogar.

Impressões dos alunos com relação ao RPG.
Gostei muito ... (A1 e A6), ... gostei demais ... (A10)

... levarei como lembrança para toda a minha vida. (A1)

Foi uma experiência incrível. (A2)

Muito ótimo. Uma das melhores realizações da minha vida foi o RPG. Choveu, fez calor e vim ao RPG e se fizesse frio, chovesse forte ao ponto de cair tempestade, ainda viria. (A3) ... foi um ótima experiência ... ... só tenho que agradecer por esse método me ajudar muito na escola. (A4)

... uma ótima iniciativa ... (A13)

Em toda a minha vida, eu nunca tinha jogado RPG ... queria muito saber como era... (A5)

... foi algo inovador e divertido

... foi uma das melhores coisas que fiz no ano ... (A8)

continua 


\begin{tabular}{|c|c|}
\hline Subcategoria & Exemplos de respostas \\
\hline & $\begin{array}{l}\text {... foi uma das melhores coisas que fiz no ano ... (A8) } \\
\text {... para mim esse RPG foi sensacional ... nunca vou esquecer } \\
\text { essa experiência incrivel que eu tive com meus amigos. (A9) } \\
\text {... uma experiência muito boa ... (A10) } \\
\text {... a experiência de jogar RPG foi emocionante ... (A11) } \\
\text {... foi muito legal ...(A15) }\end{array}$ \\
\hline
\end{tabular}

RPG como um teatro, ou filme. Ou uma maneira de sair da realidade.
... você pode se sentir livre e pode fazer coisas que na vida real não poderiam ser realizadas. (A2)

... com o RPG eu pude "sair da realidade", vivenciei um mundo diferente ... (A4)

... foi incrível, era como ser um ator de um filme... (A5)

... fez me sentir de uma maneira diferente, fora do normal, eu não era apenas uma aluna ... era um dos membros da tripulação ... estava em outro planeta salvando vidas. (A14)

Confraternização com Conheci melhor as opiniões dos meus amigos e me aproximei amigos, colaboração. um pouco mais de alguns colegas os quais não tinha tanto contato. (A1)

... legal jogar RPG na escola, ... rodeado de amigos. ...exige muita criatividade estratégia, e trabalho em equipe. (A2) ... passar mais tempo com meus amigos ... e refletir sobre ciências... ajuda você a se comunicar melhor

... consegui me abrir mais com outras pessoas ... (A4) fez com que muitos amigos se reunissem e se reconhecessem. ... deve ser espalhado nas escolas e nas famílias, trazendo a união e a felicidade de muitos. (A8)

continua 
conclusão

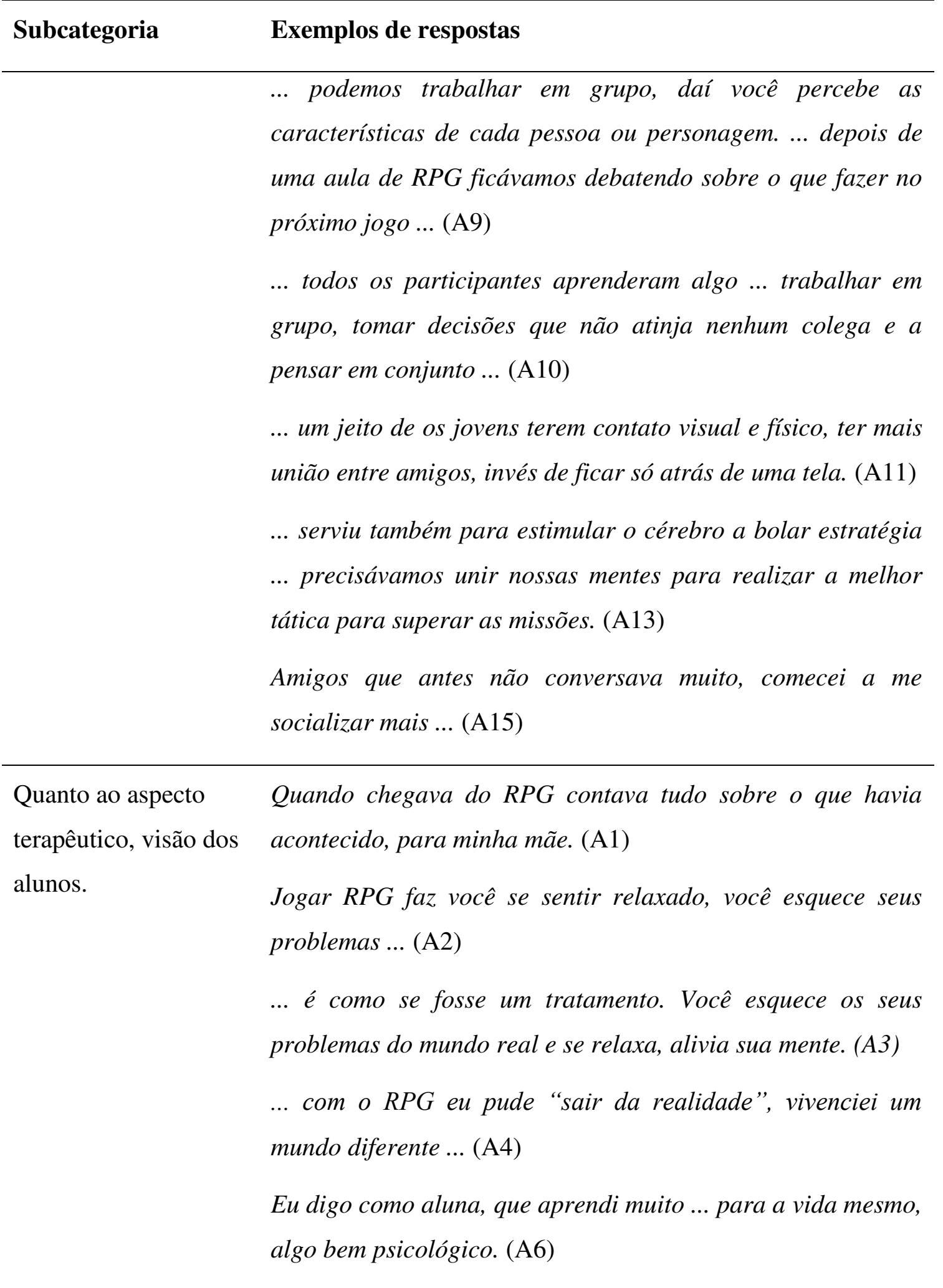

Primeiramente é importante ser estabelecido que, embora dentre os 15 estudantes que participaram da pesquisa, houvessem 6 meninas e 9 meninos, não é possível saber se a resposta é de um aluno ou aluna, pois as perguntas foram respondidas de forma anônima. 
Em algumas respostas pode-se perceber o gênero do aluno, como por exemplo em: “...eu não era apenas uma aluna... era um dos membros da tripulação..." e "Quando crescer, eu tenho vontade de ser político...". Mas, mesmo assim, como isso não é possível em todas as respostas, os sujeitos da pesquisa serão referidos aqui todos como alunos, e quando evocadas suas falas, serão referidos pelos códigos de cada um, sendo representados pela letra A e um número.

Ao interpretar as respostas dos alunos para esta pergunta, é possível notar que a experiência foi muito gratificante e positiva para eles, possibilitando aos alunos formarem ligações emocionais benéficas com a atividade proposta, pois foi realmente um momento de lazer lúdico para eles, o que talvez esteja ligado aos bons resultados que obtiveram no teste de ácido e base, e escala de pH, pois como demonstra Dias, Novaes e Rosalem (2015) a construção de ligações prazerosas dos alunos para com a atividade pedagógica, promove melhor construção do conhecimento, além de influenciar positivamente na formação, evocação e manutenção das memórias relacionadas aos conteúdos abordados na atividade pedagógica.

Também é percebido nas falas dos alunos o aspecto motivacional do role-playing game, o que é observado em todos os trabalhos a respeito do RPG, e também em todos os trabalhos à respeito do seu uso na educação, levantados na revisão bibliográfica do presente trabalho.

O papel da fantasia contribuindo para o bem estar e desenvolvimento individual e social também pode ser observado nas falas dos alunos agrupadas na subcategoria "RPG como teatro ou filme. Ou uma maneira de sair da realidade.”. O que é defendido no livro de Jones (2004) e também no livro de Rodrigues (2004), bem como nos trabalhos de Silva (2009) e Camargo (2006)

O caráter social do RPG é bastante evidenciado pelas respostas dos alunos nesta tabela, inclusive sendo possível ver os alunos apontando o benefício de se distanciarem das telas de celulares e poderem estar juntos pessoalmente, e compartilharem momentos e ideias, o que consiste em ganho quanto ao desenvolvimento individual e social do jovem, como é apontado também em todos os trabalhos sobre o uso do RPG na educação, e sobre o RPG em si, citados na revisão da literatura nesta pesquisa.

É possível por meio da análise e interpretação das falas dos alunos nesta tabela, confirmar todos os apontamentos feitos com base na observação durante o período no qual a experiência ocorreu. 
Agora com o objetivo de saber se os alunos recomendariam o uso do RPG na educação, com base na experiência que eles tiveram com esse jogo, foi feita a eles a pergunta demonstrada na tabela abaixo, a qual contem os principais trechos de suas respostas, e na maioria dos casos a resposta na íntegra.

Tabela 6 - Respostas referentes à pergunta dissertativa: "Você recomendaria o uso do RPG na escola? Ou você não recomendaria o uso do RPG na escola? Argumente sua opinião."

\section{Categoria Exemplos de respostas}

\begin{tabular}{ll}
\hline SIM, porque é uma & "Com toda a certeza recomendaria o uso do RPG na escola, \\
maneira divertida de se & porque com isso os alunos estão aprendendo e ao mesmo tempo se \\
aprender e facilita o & divertindo. Sendo assim aprender novos conteúdos se torna mais \\
aprendizado, aumenta a & legal e divertido por meio de um jogo, além de você conhecer mais \\
interação com os & sobre seus amigos e colegas, por isso recomendo sim." (A1) \\
amigos, aprendizado & "Eu recomendo, pois incentiva as crianças a estudarem mais." \\
além do currículo. &
\end{tabular}
(A2)

"Sim, pois é um dos métodos de se aprender algo a mais, por exemplo: ácido e base, não tem no meu conteúdo da matéria e no RPG aprendemos um pouco sobre isso." (A3)

"Sim, acho que seria uma maneira de aprender conteúdos novos e se interagir com o pessoal do grupo, expressando suas ideias e interesses podendo ajudar na história." (A4).

"Recomendaria o uso do RPG na escola com base no que me fez fazer nesse período, como exemplo o esforço maior na hora do estudo e as pesquisas para esclarecer os conteúdos apresentados nas conversas com participantes do RPG para debater as estratégias exercitando o raciocínio e estratégia." (A5)

"Sim, pois assim como me motivou a estudar, e a participar das atividades, isso poderia motivar outros alunos de variadas escolas e idades a estudarem e entenderem a matéria de uma forma divertida." (A6)

continua 


\begin{tabular}{|c|c|}
\hline Categoria & Exemplos de respostas \\
\hline & $\begin{array}{l}\text { "Quando crescer, eu tenho vontade de ser político, não só } \\
\text { recomendaria, como também faria um projeto de lei para levar a } \\
\text { todas as crianças a oportunidade de estudar com melhor qualidade, } \\
\text { no RPG não é necessário aparelhos eletrônicos, basta uma folha, } \\
\text { algo simples, acessível a todos. Vejo que quando utilizamos } \\
\text { brincadeiras como forma de estudo, facilita muito, não só na } \\
\text { disciplina de ciências, mas em todas as disciplinas." (A7) }\end{array}$ \\
\hline & $\begin{array}{l}\text { "Sim, pois se for como nosso professor (mestre de aventura), } \\
\text { incentiva o aluno em estudar e se esforçar." (A8) }\end{array}$ \\
\hline & $\begin{array}{l}\text { "Sim, pois o RPG é uma coisa que não deve ser recusada em } \\
\text { nenhuma escola do planeta, pois isso é muito divertido e com } \\
\text { estudo como ciências e física.". (A9) }\end{array}$ \\
\hline & $\begin{array}{l}\text { "Sim, eu recomendaria, pois é um jeito mais fácil de aprender o } \\
\text { conteúdo, já que nos divertimos ao mesmo tempo que estamos } \\
\text { estudando. Isso torna mais fácil de memorizar a matéria." (A10) }\end{array}$ \\
\hline & Sim pois uniria os alunos, ensina de forma que eles gostam." (A11) \\
\hline & $\begin{array}{l}\text { "Particularmente recomendo o uso do RPG na escola, já que essa é } \\
\text { uma forma divertida de aprender qualquer matéria. No caso foi } \\
\text { ciências, mas nada impede de jogar RPG com o objetivo de ensinar } \\
\text { outra matéria como História (exemplo: Guerra Mundial)." (A12) }\end{array}$ \\
\hline & $\begin{array}{l}\text { "Sim, pois com o RPG, nós aprendemos sem nem saber que } \\
\text { estávamos aprendendo, ou seja, o aprendizado estava oculto por } \\
\text { trás de uma história envolvente." (A13) }\end{array}$ \\
\hline & $\begin{array}{l}\text { Eu recomendo o uso do RPG na escola, porque o jogo nos fez } \\
\text { aprender ciências e também outras matérias (disciplinas), } \\
\text { possibilitou ter mais interação entre os alunos, alguns que antes } \\
\text { não conversavam, passaram a conversar, a ser mais respeitosos } \\
\text { com os outros, cada um falar na hora certa, evitar falar palavrões, } \\
\text { ou seja palavras horriveis, e teve a história que podemos colocar o } \\
\text { que aprendemos no dia-a-dia, tanto nosso, quanto dos personagens, } \\
\text { histórias que a maioria das pessoas gostam." (A14) }\end{array}$ \\
\hline
\end{tabular}

Continua 
conclusão

\begin{tabular}{ll}
\hline Categoria & Exemplos de respostas \\
\hline $\begin{array}{l}\text { NÃO, porque gasta } \\
\text { muito tempo. }\end{array}$ & $\begin{array}{l}\text { "Não, pois consome muito tempo da aula para ter pouca matéria, o } \\
\text { tempo não é bem utilizado." (A15) }\end{array}$ \\
\hline
\end{tabular}

Primeiramente segue a discussão das argumentações dos alunos para a recomendação do uso do RPG na escola. Depois será discutida a argumentação do aluno A15 que não recomenda o uso do RPG na escola.

Podemos elencar os seguintes motivos, ou argumentos, que os alunos estabeleceram a favor do uso do role-playing game na escola: motivação, socialização, possibilidade de aprender conteúdos extras aos apresentados no currículo da disciplina, participação ativa, cooperação, trabalho em equipe, interação, promoveu transformação para melhor levando a maior dedicação aos estudos, melhora e facilita o aprendizado, incentivo a pesquisa, o fato do RPG ser uma tecnologia educacional de baixo custo, ludicidade, interdisciplinaridade, fantasia, incentiva a imaginação, promove empatia e respeito, o uso da narrativa de ficção e possibilidade de aprender sem nem saber que está aprendendo (o que pode ser chamado de educação informal).

No presente trabalho o RPG foi proposto como uma atividade voluntária e complementar as aulas de ciências, no período da tarde, ou seja fora do período de aula destes alunos.

Objetivando aproveitar todas as características lúdicas do RPG, pois como foi utilizado neste experimento como um jogo no sentido pleno da palavra, conforme definido por Huizinga (2008), com o objetivo de potencializar o ensino de ciências, tanto pela educação informal, definida por Brougère (2002), como pela educação formal, na forma dos exercícios de química propostos durante algumas jogadas, conforme explicado anteriormente na Metodologia, ainda assim sem quebrar a voluntariedade e a ludicidade, pois em nenhum momento foi obrigatório para os alunos a realização dos exercícios, e eles eram aplicados dentro do contexto do jogo, sem haver formalidades de notas, ou entrega dos exercícios resolvidos.

E ao se analisar os argumentos que os alunos expressaram a favor do uso do RPG, pode-se refletir que, para este grupo de alunos, o RPG proporcionou diversos ganhos educacionais, individuais e sociais, os quais são os objetivos da nova educação, como 
afirmam Becker (2012), Carvalho (2013), Dowbor (2001), Moraes (2016), Silva (2009) e Vgot (2010).

Por tanto, pode-se refletir, a partir da interpretação das respostas dos alunos, que existe um alinhamento entre o que este uso do RPG proporcionou à formação destes jovens e os caminhos para a nova educação expostos na revisão bibliográfica. Indicando diversas possibilidades deste uso do RPG para o cenário educacional.

Quanto a interpretação da resposta contra o uso do RPG na escola, percebe-se que o argumento de A15 foi muito pertinente, pois de fato é inegável que não é viável utilizar dois meses de período letivo, para ensinar sobre ácido, base e escala de pH e densidade, os quais foram os assuntos de ciência que receberam maior ênfase na campanha do jogo, seguidos pelas três leis de Newton e Zoologia de artrópodes, que receberam menor ênfase, seguidos de diálogos entre o professor e os alunos realizados em determinados momentos da campanha, sobre algumas outras temáticas da ciência, como por exemplo, astronomia, evolução, ecossistemas, de acordo com o que estava em cena na aventurai no momento.

Ainda que tenham sido de grande riqueza a abordagem desses temas em um jogo, continua sendo, como disse A15, muito tempo de aula para pouco conteúdo, não sobraria tempo para abordar todos os conteúdos previstos ao longo do ano. Sendo exatamente por este fator, que a presente pesquisa trouxe a proposta do uso do RPG no período fora da aula.

Assim como o RPG foi aplicado nesta pesquisa como atividade voluntária, o que confere ao jogo o significado verdadeiro de jogo, e também limitando um número máximo de 8 jogadores por turma, somados ao mestre da aventura, para se aplicar o RPG na sua forma de maior aproveitamento, pois é um jogo que funciona melhor com grupos pequenos, para que a narrativa possa acontecer de maneira que todos os jogadores tenham protagonismo na história.

Por isso é mencionado na introdução deste trabalho, que sua proposta é ao invés de buscar abrir um espaço na aula para o jogo, foi objetivado abrir um espaço no jogo para aula. Ou seja, abrir uma dimensão para a educação, dentro deste jogo.

Pois talvez seja desta forma, como atividade complementar e com participação voluntária dos alunos, que o RPG pode manifestar suas maiores contribuições para a educação. Quando orquestrado por um professor que tenha autonomia sobre o uso desse jogo, um professor que se considere RPGista, que esteja devidamente amparado e preparado para exercer autoria sobre o recurso role-playing game, criando, modificando e 
reinventando o jogo em favor de sua proposta pedagógica. Como afirmam os autores Fairchild (2004) e Silva (2009).

\subsection{AS IMPRESSÕES DOS ALUNOS QUANTO AO CONTATO COM CONTEÚDOS DA DISCIPLINA DE CIÊNCIA POR MEIO DO ROLE-PLAYING GAME:}

Da mesma forma que foi feito no tópico anterior, neste também é feita a análise das respostas dos alunos a duas questões dissertativas, a diferença é que neste tópico foi elaborada uma única tabela unindo os principais trechos das respostas dos alunos para ambas as perguntas. A primeira pergunta é a pergunta aberta também analisada no tópico anterior, e a segunda pergunta é referente ao contato com conteúdos de ciência por meio do role-playing game.

O motivo de ter sido unidos os principais trechos para ambas as respostas foi que, na pergunta aberta os alunos expressaram muitas opiniões sobre a aprendizagem de ciências pelo jogo de RPG, como na tabela anterior o foco foram as sensações e impressões que os alunos tiveram ao jogar RPG, estes trechos referentes à aprendizagem de ciências se encaixaram melhor nesta tabela, para facilitar a organização das respostas e a interpretação tanto por parte do autor quanto do leitor.

Tabela 7 - Respostas referentes às perguntas dissertativas: "Você aprendeu algum conceito novo de ciências jogando o RPG? Se sim quais foram estes conteúdos? E houve algum momento da história do RPG em que você e sua equipe tiveram de usar esse conhecimento em ciências? Se sim, descreva como foi esse momento." E também: "Escreva um texto, de no mínimo 10 linhas e no máximo 30 linhas, descrevendo como foi para você vivenciar essa experiência de jogar RPG na escola."

\begin{tabular}{ll}
\hline Subcategoria & Exemplos de respostas \\
\hline Melhora no & Aprendi coisas novas. Aprendi o conceito de ácido e base e \\
aprendizado de & densidade que ainda não sabia (A1) \\
conceitos de Ciências & Aprendi sobre ácido e base, houveram momentos na história \\
& que usamos isso para salvar o John Willians. (A2) \\
& Pode melhorar o desempenho na escola. Aprendi sobre ácidos e \\
& base, pH e densidade, no momento em que tivemos que salvaro \\
& comandante do ninho dos escorpiões e na hora de sacrificar as \\
& baleias flutuantes para destruir os piratas. (A3)
\end{tabular}

continua 


\begin{tabular}{|c|c|}
\hline Subcategoria & Exemplos de respostas \\
\hline & $\begin{array}{l}\text { Consegui conhecimentos a mais nas matérias de ciências. } \\
\text { Escala de pH e densidade, quando precisamos medir o grau } \\
\text { de acidez dos poços e quando tivemos que enfrntar alguns } \\
\text { bichos gigantes que tinham um gás dentro. (A4) }\end{array}$ \\
\hline & $\begin{array}{l}\text { Pode aprender enquanto está se divertindo. Vi que o RPG na } \\
\text { escola é incrível. Vi coisas e aprendi muito mais disposta do } \\
\text { que em uma aula teórica. Aprendi sobre ácido e base, tabela } \\
\text { de pH e densidade. E precisamos usar esse conhecimento } \\
\text { quando tivemos que fazer o líquido ácido virar neutro. (A5) }\end{array}$ \\
\hline & $\begin{array}{l}\text { Achei o método divertido. Torna tudo mais agradável. Passa } \\
\text { a se interessar mais pela matéria. Aprendi sobre o pH, que } \\
\text { fala de ácido e base, que misturados em uma certa quantidade } \\
\text { torna água e sal. A gravidade foi utilizada para entender } \\
\text { melhor a "baleia voadora" e as manobras da nave. (A6) }\end{array}$ \\
\hline & $\begin{array}{l}\text { Inovador e divertido, estudar brincando, aprendi coisas novas } \\
\text { como ácido e base (pH) que em muitos momentos foram } \\
\text { usados os conhecimentos científicos como na parte do lago } \\
\text { ácido e do bicho que flutua como dirigível. (A7) }\end{array}$ \\
\hline & Temas de ciências - pH ácidos e bases. (A8) \\
\hline & $\begin{array}{l}\text { Aumentou o meu apetite em estudar. Aprendi conteúdos de } \\
\text { várias matérias, como física, química e a melhor que é } \\
\text { história, pois muda tudo, o tempo, as roupas, as armas, as } \\
\text { civilizações ... e que nesse planeta o ar era diferente então } \\
\text { tinha que usar máscaras. (A9) }\end{array}$ \\
\hline & $\begin{array}{l}\text { Mostrou outra forma de dar aula. Já sabia sobre ácido e base, } \\
\text { mas durante o RPG eu aprendi como transformar o ácido em pH } \\
\text { neutro e também aprendi mais sobre a densidade do ar. Houve } \\
\text { momentos que foram emocionantes porque foi legal ter que } \\
\text { utilizar algo que aprendemos. Isso faz com que os alunos } \\
\text { guardem o que aprenderam. (A10) }\end{array}$ \\
\hline
\end{tabular}

continua 
conclusão

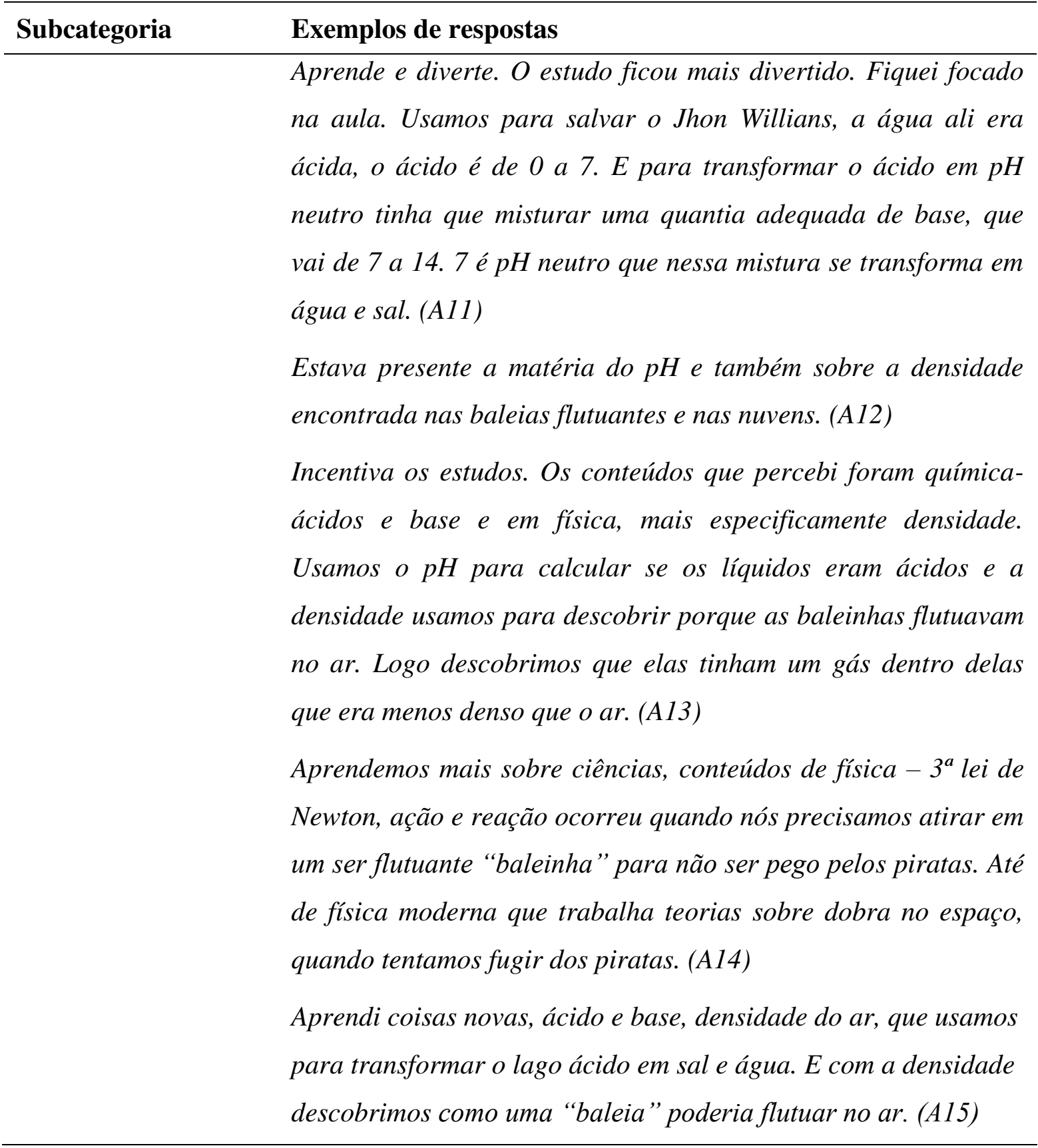

Para a compreensão das respostas dos alunos nesta tabela, é necessária a compreensão da narrativa do jogo, da história que foi desenvolvida durante a campanha. Um dos motivos pelos quais se deu ênfase neste trabalho para o resumo da história da campanha. Pois assim o leitor está familiarizado com os contextos que alguns os alunos levantaram em suas respostas, os quais são referentes a ficção da qual seus personagens participaram.

Narrativa que os jogadores também ajudaram a contar, pois como já explicado anteriormente, o RPG é um jogo de contar histórias e, mesmo o mestre criando e 
preparando a história anteriormente ao momento da sessão, as decisões dos jogadores podem muitas vezes não serem as decisões que o mestre previu, o que requer habilidade do mestre de improvisar e ainda assim manter a narrativa envolvente. Portando as ações dos personagens, por meio das escolhas dos jogadores, interferem no rumo da história, fazendo com que o final da história nunca seja fixo, ou seja, pode acabar sendo um final diferente ao que o mestre preparou.

Como mencionado na análise dos resultados do teste ácido e base, que o aprendizado de ciências pelos alunos, por meio desta experiência com RPG, ficaria mais claro na análise das respostas dissertativas dos alunos. Pode-se notar nesta tabela o quão presente foram os temas de ciências no discurso dos alunos em suas respostas.

A interpretação das respostas nesta tabela indicou que durante as sessões de RPG ocorreu: aprendizagem ativa por meio da resolução de problemas, interdisciplinaridade ou pelo menos elevado potencial para tanto, aprendizagem com significado e aplicação imediata, incentivo aos estudos, protagonismo do aluno na construção de seu conhecimento e construção conjunta do conhecimento. Esta aprendizagem por meio do RPG também é verificada na literatura em todas as pesquisas que aplicaram RPG no processo de ensino e aprendizagem.

Enfatizando o potencial do uso do RPG, como um atividade voluntária e complementar as aulas, para o ensino de ciências e para a educação como um todo. 


\section{CONCLUSÕES}

Ao analisar e interpretar todos os dados coletados é possível concluir que houve melhora no aprendizado de ciências, por meio da experiência com o uso do RPG, como uma atividade voluntária e complementar às aulas, para o ensino de ciências.

Os alunos demonstraram aprender de forma prazerosa, não foi percebido neles, a quebra da ludicidade pela inserção dos conteúdos de ciências durante as sessões de RPG. Portanto o contato dos alunos com conteúdos de ciências, por meio desta metodologia, foi positivo, favorecendo ao aprendizado destes jovens, principalmente na área de ciências. De modo que a atividade com RPG foi complementar as aulas, pode ter exercido grande contribuição no desempenho destes alunos nas aulas no período da manhã.

As possibilidades educacionais da implementação do role-playing game no ambiente escolar, como uma atividade pedagógica complementar e voluntária, são muitas: desde aplicações eventuais como feito nesta pesquisa, em períodos de dois a três meses, à atividades extras propostas pelos professores, de maneira voluntária, possibilitando um reforço lúdico dos estudos realizados pelos alunos durante as aulas curriculares de manhã. Ou ainda, o uso constante do RPG ao longo do ano letivo, desta forma, como um reforço a aprendizagem, e oficina fomentadora de criatividade, narrativa, cooperação e educação social, durante todo o ano letivo, acompanhando o desenvolvimento dos alunos.

O RPG poderia vir a ser uma atividade padrão da escola, voluntária oferecida para os alunos que quisessem participar, formando turmas, orientadas por um docente RPGista, tal qual são as aulas de música, esportes e dança nas escolas que as apresentam. Poderia ser uma oficina de role-playing game, as escolas poderiam ter a oficina do xadrez, a oficina de textos, a oficina de dança, teatro... e a oficina de RPG.

A proposta do trabalho foi, em uma expressão simples, abrir espaço no jogo para aula. Pode se dizer que essa proposta foi cumprida, pois de fato foi aplicado um jogo, e de fato nele houve espaço para a educação agir. E os resultados puderam ser mensurados de diversas formas, dados observacionais e interpretação de questionários, tanto múltipla escolha quando dissertativos, além de um teste múltipla escolha. E foi possível observar coerência entre os resultados obtidos pelos diferentes instrumentos de coleta de dados.

O trabalho também demonstrou resultados semelhantes aos obtidos na literatura quando à estudos com o uso do RPG no processo de ensino e aprendizagem. 
O role-playing game foi eficiente como estratégia educacional para o ensino de ciências, a aprendizagem dos conceitos de ciências abordados durante o jogo foi verificada. Principalmente quanto a aprendizagem dos conceitos referentes à ácido, base e escala de $\mathrm{pH}$.

Os alunos tiveram impressões positivas quanto a jogar RPG no ambiente escolar com o professor. Bem como foram positivas suas impressões sobre o contato com os conceitos de ciências por meio do RPG.

Mas o diferencial da proposta da presente pesquisa é a aplicação fora da sala de aula, dentro da escola, porém fora das paredes aprisionadoras das notas e planilhas, longe das correntes da imposição do material didático, em um ambiente que permite maior liberdade para o aluno criar, um ambiente que favorece a criatividade e a autonomia, tanto do aluno quanto do professor.

Por meio desta pesquisa podemos concluir que o uso do Role Playing Game é uma poderosa estratégia para a educação, nas mãos do docente que tenha conhecimento e autonomia sobre este jogo, que seja capaz de criar em cima dele e usa-lo para interligar conteúdos disciplinares, dentro de sua proposta didática, com a participação voluntária dos alunos e de maneira complementar às aulas.

O RPG não é a única estratégia educacional capaz de proporcionar mudanças significativas na educação e consequentemente na sociedade, existem diversas outras abordagens que também podem proporcionar tal transformação, e nem devam todas as metodologias de ensino ser substituídas pelo RPG. Mas é inegavelmente uma estratégia com elevadas possibilidades e grande potencial para a educação, sendo usada das maneiras que ela possa de fato proporcionar as qualidades relacionadas a este jogo, em conjunto com as demais metodologias existentes, sendo somada ao cenário educacional, e aplicada pelos professores que possuírem, ou desenvolverem, autonomia para tal, se assim desejarem, pois, o jogo deve sempre ser voluntário.

O estudo realizado sobre a aplicação do RPG no ensino de ciências permitiu concluir que o uso desta estratégia proporcionou maior dinamismo ao ensino e aprendizagem, permitiu aos alunos ocuparem uma posição ativa em seu aprendizado, desencadeou interações sociais importantes, facilitou o desenvolvimento de habilidades e competências para resolver problemas, ofereceu meios para que os estudantes sejam estimulados a serem imaginativos e criativos, possibilitou o trabalho em equipe, oportunizou momentos de ludicidade e propiciou a interdisciplinaridade. 


\section{REFERÊNCIAS}

AMARAL, R. R. ; BASTOS, H. F. B. N. O Roleplaying Game na sala de aula: uma maneira de desenvolver atividades diferentes simultaneamente. Revista Brasileira de Pesquisa em Educação em Ciências, Rio de Janeiro, v. 11, n. 1, p. 103-122, 2011.

ANDRADE, F. Caminhos para o uso do RPG na Educação. Revista eletrônica do grupo ALEPH, Rio de Janeiro, v. 2, n. 09, fev./mar. 2006. Disponível em: $<$ http://www.uff.br/aleph/textos_em_pdf/caminhos_para_o_uso_do_rpg_na_educacao.pdf >. Acesso em 07 Jul. 2016

ANDRADE, M. R. D.; CARNEIRO, C. R. A utilização do RPG: Role Playing Game como instrumento pedagógico para a prática da leitura, oralidade e escrita.O Professor PDE e os Desafios da Escola Pública Paranaense, Curitiba, v. 1, n. 1, p. 1-11, 2007. Disponível em:

<http://www.diaadiaeducacao.pr.gov.br/portals/cadernospde/pdebusca/producoes_pde/200 7_ufpr_port_artigo_maria_regina_domingues_de_andrade.pdf $>$ Acessado em 07 Jul. 2016.

ARAUJO, R. B.; OLIVEIRA, M. M. A.; CEMI, J. Desenvolvimento de role-playing game para prevenção e tratamento da dependência de drogas na adolescência. Psicologia: Teoria e Pesquisa, Brasília , v. 27, n. 3, p. 347-355, Set. 2011.

BARBOSA, S. L. P.; CARVALHO, T. O. Jogos matemáticos como metodologia de ensino aprendizagem das operações com números inteiros. Portal Educacional do Estado do Paraná, 2008. Disponível em:

$<$ http://www.diaadiaeducacao.pr.gov.br/portals/pde/arquivos/1948-8.pdf> Acesso em 12 jul 2016.

BECKER, F. Educação e construção do conhecimento: revista e ampliada. Porto Alegre: Penso Editora, 2016.

BETTOCCHI, E.; KLIMICK, C.. O lugar do virtual no RPG, o lugar do RPG no Design. In: SIMPÓSIO DO LABORATÓRIO DA REPRESENTAÇÃO SENSÍVEL, 2., 2003, Rio de Janeiro. Anais... . Rio de Janeiro: Atopia, 2003. p. 1 - 15.

BOLZAN, R. F. F. A.. O aprendizado na internet utilizando estratégias de Roleplaying Game (RPG). 2003. 302 f. Tese (Doutorado) - Curso de Engenharia de Produção, Universidade Federal de Santa Catarina, Florianópolis, 2003.

BROUGÈRE, G. Lúdico e educação: novas perspectivas. Linhas Criticas, Brasília, v. 8, n. 14, p.5-21, jun. 2002. Disponível em:

<http://periodicos.unb.br/index.php/linhascriticas/article/view/6491/5247>. Acesso em: 05 jul. 2016. 
CAMARGO, M. E. S. A. Jogos de papéis (RPG) em diálogo com a educação ambiental: aprendendo a participar da gestão dos recursos hídricos na região metropolitana de São Paulo. 2006. 175 f. Tese (Doutorado) - Curso de Ciência Ambiental, Universidade de São Paulo, São Paulo, 2006.

CARVALHO, A. M. P. (org). Ensino de ciências por investigação: condições para implementação em sala de aula. São Paulo: Cengage Learning, 2013.

CAVALCANTI, E. L. D.; SOARES, M. H. F. B. O uso do jogo de roles (roleplaying game) como estratégia de discussão e avaliação do conhecimento químico. Revista

Electrónica de Enseñanza de las Ciências, Vigo, Espanha, v. 8, n. 1, p. 255-282, 2009.

Disponível em: <http://reec.uvigo.es/volumenes/volumen8/ART14_Vol8_N1.pdf> Acesso em: 10 Jul. 2016.

CHUNG, T. Table-top role playing game and creativity. Thinking Skills and Creativity, Amsterdan, v. 8, p. 56-71, 2013.

CORTELAZZO, I, B. C. Colaboração, trabalho em equipe e as tecnologias de comunicação: relações de proximidade em Cursos de Pós-Graduação. 2000, Tese (Doutorado em Educação) - Faculdade de Educação, Universidade de São Paulo, 2000. Disponível em: <http://www.boaaula.com.br/iolanda/tese/ensinar.htm\#_Toc290309243>. Acesso em: 20 jul 2016.

CORTELAZZO, I, B. C. Redes de comunicações e educação escolar: a atuação de professores em comunicações telemáticas. 1996, Dissertação (Mestrado em Educação) Faculdade de Educação, Universidade de São Paulo, 1996. Disponível em:

$<$ http://www.boaaula.com.br/iolanda/dissertacao/sumario.htm\#sumario $>$. Acesso em: 20 jul 2016.

COSTA, F. P. S.; LIMA, J. E.; ALMEIDA, R. P.. RPG (Roleplaying Game) e seu potencial pedagógico. Revista de Ciências da Educação, Americana, n. 24, p.323-349, jan. 2011.

COUTINHO, C. P.; LISBÔA, E. S. Sociedade da informação, do conhecimento e da aprendizagem: desafios para educação no século XXI. Revista de Educação, Braga, v. 18, n. 1, p. 5-22, 2011.

CRUZ, J. M. O. Processo de ensino-aprendizagem na sociedade da informação. Educação \& Sociedade, Campinas, v. 29, n. 105, p.1023-1042, dez. 2008.

DIAS, N.; NOVAES, F.; ROSALEN, M.. Processo de aprendizagem no ensino de Ciências mediado por jogo digital: defluência na memória e cognição. In: ENCONTRO

INTERNACIONAL TECNOLOGIA, COMUNICAÇÃO E CIÊNCIA COGNITIVA, 2. 2015, São Paulo. Anais eletrônicos. São Paulo: Tecccog, 2015. p. 1 - 14. Disponível em: 
<http://www.walterlima.jor.br/anaistecccog/index.php/anais/article/viewFile/57/59>. Acesso em: 02 ago. 2016.

DOWBOR, L. Tecnologias do conhecimento: os desafios da educação. Petrópolis: Vozes, 2001. 30p.

DYSON, S. B. et al. The effect of tabletop role-playing games on the creative potential and emotional creativity of Taiwanese college students. Thinking Skills And Creativity, Amsterdan, v. 19, p.88-96, 2015.

FAIRCHILD, T. M.. O discurso de escolarização do RPG. 2004. 165 f. Dissertação (Mestrado) - Curso de Educação, Universidade de São Paulo, São Paulo, 2004.

FERRACIOLI, L. Aprendizagem, desenvolvimento e conhecimentona obra de Jean Piaget: uma análise do processode ensino-aprendizagem em Ciências. Revista Brasileira de Estudos Pedagógicos, Brasília, v. 80, n. 194, p.5-18, abr. 1999.

FERREIRA, J. H. B. P. et al. Aprendendo sobre a relação presa-predador por meio de jogos pedagógicos. São Paulo: Cultura Acadêmica, 2007. p. 604-618.

FERREIRA, R. C. et al. O Role Playing Game (RPG) como ferramenta de aprendizagem no ensino fundamental e médio. Livro Eletrônico dos Núcleos de Ensino da Unesp. São Paulo: Cultura Acadêmica Editora, 2007. Disponível em: $<$ http://unesp.br/portal\#!/prograd/e-livros-prograd/>. Acessado em 15, ago, 2017

GADOTTI, M. A Escola e o professor: Paulo Freire e a paixão de ensinar. São Paulo: Publisher Brasil, 2007. 112 p.

GAMBERINI, L. et al. A game a day keeps the doctor away: a short review of computer games in mental healthcare. Journal Of Cybertherapy And Rehabilitation, Brussels, v. 1, n. 2, p.127-145, jun. 2008.

HARGREAVES, A. Teaching in the knowledge society: education in the age of insecurity. New York: Teachers College Press, 2003.

HUIZINGA, J. HOMO LUDENS: o jogo como elemento da cultura. 5. ed. São Paulo: Perspectiva, 2008. 256 p.

JONES, G.. Brincando de matar monstros: por que as crianças precisam de fantasia, videogames e violência de faz de conta. São Paulo: Conrad Livros, 2004. 298 p. 
JULIANI, A.; PAINI, L. A importância da ludicidade na prática pedagógica: em foco o atendimento às diferenças. Portal Educacional do Estado do Paraná, 2008. Disponível em: <http://www.diaadiaeducacao.pr.gov.br/portals/pde/arquivos/2113-8.pdf> Acesso em 12 jul 2016.

KARWOWSKI, M.; SOSZYNSKI, M.. How to develop creative imagination?: Assumptions, aims and effectiveness of Role Play Training in Creativity (RPTC). Thinking Skills And Creativity, Amsterdan, v. 3, n. 2, p.163-171, 2008.

KLIMICK, C.; BETTOCCHI, E.; REZENDE, R.. Projeto Incorporais: método e material lúdico-didático para professores e estudantes do ensino médio. Triades, Rio de Janeiro, v. 2, n. 1, p.1-15, dez. 2012. Disponível em: <http://www.revistatriades.com.br/blog/wpcontent/uploads/2014/08/incorporais.pdf>. Acesso em: 25 ago. 2016.

LIMA, D. B., A aprendizagem baseada em problemas e a construção de habilidades como ferramentas para o ensino-aprendizagem nas ciências da natureza. $2015.116 \mathrm{f}$. Dissertação (Mestrado em Educação em Ciências) - Instituto de Ciências Básicas de Saúde, Universidade Federal do Rio Grande do Sul, Porto Alegre, 2015.

LOPES, L. M. C.; KLIMICK, C.; CASANOVA, M. A. Relato de uma experiência de sistema híbrido no ensino fundamental: Projeto Aulativa. Revista Brasileira de Aprendizagem Aberta e a Distância. Associação Brasileira de Educação à Distância, São Paulo, v. 2, 2003.

MARIN, M. J. S. et al. Aspectos das fortalezas e fragilidades no uso das metodologias ativas de aprendizagem. Revista Brasileira de Educação Médica, Rio de Janeiros , v. 34, n. 1, p.13-20, mar. 2010.

MONTEIRO, M. A. A. et al. Os textos paradidáticos e a história da ciência em sala de aula: Um estudo sobre a ideologia do discurso docente. In: ENCONTRO NACIONAL DE PESQUISA EM EDUCAÇÃO EM CIÊNCIAS, 4., 2003, Bauru. Anais eletrônicos ... Bauru: Abrapec, 2003. p. 1 - 9. Disponível em:

$<$ http://fep.if.usp.br/ profis/arquivos/ivenpec/Arquivos/Orais/ORAL137.pdf>. Acesso em: 16 jul. 2016.

MONTEIRO, M. A. A.; GERMANO, J. S. E.; MONTEIRO, I. C. C.. A Utilização de recursos multimídias em aulas de Física a partir do referencial teórico de Vigotski. In: ENCONTRO DE PESQUISA EM ENSINO DE FÍSICA, 11., 2008, Curitiba. Anais eletrônicos... . Curitiba: Ufpr, 2008. p. 1 - 10. Disponível em:

$<$ http://www.sbf1.sbfisica.org.br/eventos/epef/xi/atas/resumos/T0115-1.pdf >. Acesso em: 15 jul. 2016.

MONTEIRO, M.A.A; MONTEIRO, I.C.C; AZEVEDO, T.C.A.M. visões de autonomia do professor e sua influência na prática pedagógica. Ensaio Pesquisa em Educação em 
Ciências. Belo Horizonte, v.12, n.3, p.117-130, 2010. Disponível em: $<$ http://www.portal.fae.ufmg.br/seer/index.php/ensaio/article/view/527/518>. Acesso em: 16 jul. 2016.

MORAES, M. C. Paradigma educacional emergente. In: CONGRESSO DE EDUCAÇÃO BÁSICA, 6., 2016, Florianópolis. Anais... Florianópolis: Prefeitura de Florianópolis, 2016.

MOREIRA, H.; CALEFFE, L. G. Metodologia da pesquisa para o professor pesquisador. 2. ed. Rio de Janeiro: Lamparina, 2008. 245 p.

NEVES, M. F.; DAMIANI, R. A. Vygotsky e as teorias da aprendizagem. Unirevista, São Leopoldo, v. 1, n. 2, p. 1-10, 2006. Disponível em:

<http://www.miniweb.com.br/Educadores/Artigos/PDF/vygotsky.pdf >. Acesso em: 14 jul. 2016.

OLIVEIRA, A. A.; RIBEIRO, S. A. B. Um modelo de role-playing game (rpg) para o ensino dos processos da digestão. Itinerarius Reflectionis, Jataí, v. 2, n. 13, 2012. Disponível em: <https://www.revistas.ufg.br/rir/article/view/22340/19245>. Acesso em: 15 jul. 2016.

OLIVEIRA, R. C.; PIERSON, A. H. C.; ZUIN, V. G. O uso do Role Playing Game (RPG) como estratégia de avaliação da aprendizagem no Ensino de Química. In: ENCONTRO NACIONAL DE PESQUISA EM EDUCAÇÃO EM CIÊNCIAS, 7., 2009, Florianópolis. Anais Eletrônicos... Florianópolis: ABRAPEC, 2009. Disponível em: $<$ http://posgrad.fae.ufmg.br/posgrad/viienpec/pdfs/961.pdf> Acesso em 08 jul 2016.

PERRENOUD, P. Dez novas competências para uma nova profissão. Pátio. Revista pedagógica. Porto Alegre, n. 17, p. 8-12, 2001.

POZO, J. I.; CRESPO, M. A. G.. A aprendizagem e o ensino de ciências: do conhecimento cotidiano ao conhecimento científico. 5. ed. Porto Alegre: Artmed, 2009. $296 \mathrm{p}$.

RAMOS, D. K. Jogos eletrônicos e aprendizagem: aspectos motivacionais na percepção de jovens jogadores. Revista NUPEM, Campo Mourão, v. 7, n. 12, p. 209-225, 2015.

RANDI, M. A. F.; CARVALHO, H. F.. Aprendizagem através de Role-Playing Games: uma abordagem para a educação ativa. Revista Brasileira de Educação Médica, Rio de Janeiro, v. 37, n. 1, p.80-88, mar. 2013. 
REEVE, J. Why teachers adopt a controlling motivating style toward students and how they can become more autonomy supportive. Educational Psychologist, Philadelphia, v. 44, n. 3, p. 159-175, 2009.

REZENDE, M.; COELHO, C. P.. A utilização do Role-Playing game (RPG) no ensino de biologia como ferramenta de aprendizagem investigativo/cooperativa. In: CONADE, CONGRESSO NACIONAL DE EDUCAÇÃO DE JATAÍ, 15., 2009, Jataí. Anais ... . Jataí, UFG, 2009. p. 1 - 10.

RODRIGUES, S. Roleplaying game e a pedagogia da imaginação no Brasil. Rio de Janeiro: Bertrand Brasil, 2004.

ROSA, M. Pesquisa qualitativa em Educação Matemática à distância: aspectos importantes do uso do Role Playing Game como procedimento metodológico de pesquisa. Educar em Revista, Curitiba, n. 45, p.231-258, set. 2012.

ROSA, M.. Role Playing Game Eletrônico: uma tecnologia lúdica para aprender e ensinar Matemática. 2004. 184 f. Dissertação (Mestrado) - Curso de Educação Matemática, Instituto de Geociências e Ciências Exatas, Universidade Estadual Paulista, Rio Claro, 2004.

SALDANHA, A. A.; BATISTA, J. R. M. A concepção do role-playing game (RPG) em jogadores sistemáticos. Psicologia: Ciência e Profissão, Brasília, v. 29, n. 4, p.700-717, 2009.

SCHMIT, W. L.; MARTINS, J. B.. RPG e Vigotski:: perspectivas para a prática pedagógica. In: CONGRESSO NACIONAL DE EDUCAÇÃO - EDUCERE, 10., 2011, Curitiba. Anais eletrônicos. Curitiba: PUC-PR, 2011. p. 7076 - 7089. Disponível em: <http://educere.bruc.com.br/CD2011/pdf/5469_3294.pdf>. Acesso em: 25 ago. 2016.

SILVA, M. V. O jogo de papéis (RPG) como tecnologia educacional e o processo de aprendizagem no ensino médio. 2009. 174 f. Dissertação (Mestrado em Educação), Universidade Tuiti do Paraná, Curitiba, 2009.

SOARES, A. N. et al. Role Playing Game (RPG) na graduação em enfermagem: potencialidades pedagógicas. Revista Eletrônica de Enfermagem, Goiânia, v. 18, p.1-11, dez. 2016. Disponível em: <https://revistas.ufg.br/fen/article/view/37672/21999>. Acesso em: 20 ago. 2016.

SOARES, A. N. et al. The Role Playing Game (RPG) as a pedagogical strategy in the training of the nurse: an experience report on the creation of a game. Texto \& Contexto Enfermagem, Florianópolis, v. 24, n. 2, p.600-608, jun. 2015. 
STAR TREK, 2009. Diretor: J. J. Abrams, Música: Michael Giacchino, Produção: Bad Robot Productions e Spyglass Entertainment, Distribuição: Paramount Pictures.

STAR WARS: Episódio V - O Império Contra-Ataca, 1984. Diretor: Irvin Kershner, Música: John Wilians, Produção: Lucasfilm, Distribuição: 20th Century Fox, Franquia Walt Disney.

SUNG, H.; HWANG, G.. A collaborative game-based learning approach to improving students learning performance in science courses. Computers \& Education, v. 63, p.4351, abr. 2013. Disponível em:

<http://www.sciencedirect.com/science/article/pii/S0360131512002849>. Acesso em: 11 set. 2016.

VIEIRA, M. RPG \& Educação: Pensamentos soltos. Curitiba: Íthala, 2012. 143 p.

VIGOSTKY, L. S. Psicologia pedagógica. 3. ed. São Paulo: Martins Fontes, 2010. 576 p.

VOGT, C. Ensino e aprendizagem: problemas como solução. ComCiência, Campinas, n. 115, Fev. 2010. Editorial. 


\section{ANEXO A: TESTE ÁCIDO, BASE E ESCALA DE PH}

Utilização do RPG para o ensino de ciências no oitavo ano do Ensino Fundamental II

Questões sobre Ácido, Base e escala de pH.

1) (ENEM) (alterada)

O suco extraído do repolho roxo pode ser utilizado como indicador do caráter ácido ou básico de diferentes soluções. Misturando-se um pouco de suco de repolho e da solução, a mistura passa a apresentar diferentes cores, segundo sua natureza ácida ou básica, de acordo com a escala abaixo.

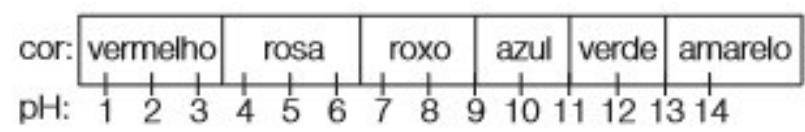

Algumas soluções foram testadas com esse indicador, produzindo os seguintes resultados:

\begin{tabular}{|l|c|}
\hline \multicolumn{1}{|c|}{ Material } & Cor \\
\hline I - amoníaco & verde \\
\hline II - leite de magnésia & azul \\
\hline III - vinagre & vermelho \\
\hline IV - leite de vaca & rosa \\
\hline
\end{tabular}

De acordo com esses resultados, as soluções I, II, III e IV têm, respectivamente, caráter:
a) Ácido, básico, básico, ácido.
b) Ácido, básico, ácido, básico.
c) Básico, ácido, básico, ácido.
d) Ácido, ácido, básico, básico.
e) Básico, básico, ácido, ácido.

2) A escala de pH ou potencial hidrogeniônico foi criada para que se possa expressar a acidez ou alcalinidade das soluções em valores que variam de 0 a 14, de acordo com a quantidade de $\mathrm{H}^{+}{\text {ou } \mathrm{OH}^{-}}^{-}$ presentes. Quanto a escala de $\mathrm{pH}$ assinale a alternativa correta:
a) Uma substância que apresente pH 9 é uma substância ácida.
b) Somente os ácidos são corrosivos, as bases não são corrosivas portanto não requerem cuidado ao serem manuseadas.
c) Uma substância que apresente pH 8 é uma substância básica (alcalina).
d) Uma substância que apresente pH 7 é uma substância ácida.
e) Uma substância que apresente pH 2 é uma substância básica (alcalina).

3) Da reação química de neutralização entre ácido e base, resulta:
a) água somente.
b) hidrogênio somente. 

c) fósforo somente.
d) sal e água.
e) Fosfato somente.

4) Ao reagir uma substância básica com uma substância ácida em proporções adequadas, ocorre uma reação de neutralização entre ácido e base. A mistura resultante desta reação química apresenta:
a) $\mathrm{pH}$ entre 1 e 3 .
b) $\mathrm{pH} 9$.
c) $\mathrm{pH} 14$.
d) $\mathrm{pH}$ entre 8 e 12 .
e) $\mathrm{pH} 7$. 